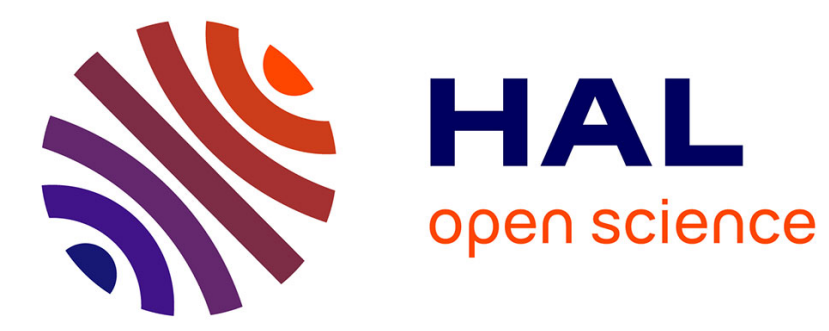

\title{
Jurassic paleogeography of the Tian Shan: An evolution driven by far-field tectonics and climate
}

Julien Morin, Marc Jolivet, Cécile Robin, Gloria Heilbronn, Laurie Barrier, Sylvie Bourquin, Yingying Jia

\section{- To cite this version:}

Julien Morin, Marc Jolivet, Cécile Robin, Gloria Heilbronn, Laurie Barrier, et al.. Jurassic paleogeography of the Tian Shan: An evolution driven by far-field tectonics and climate. Earth-Science Reviews, 2018, 187, pp.286-313. 10.1016/j.earscirev.2018.10.007 . insu-01893611

\section{HAL Id: insu-01893611 https://hal-insu.archives-ouvertes.fr/insu-01893611}

Submitted on 11 Oct 2018

HAL is a multi-disciplinary open access archive for the deposit and dissemination of scientific research documents, whether they are published or not. The documents may come from teaching and research institutions in France or abroad, or from public or private research centers.
L'archive ouverte pluridisciplinaire HAL, est destinée au dépôt et à la diffusion de documents scientifiques de niveau recherche, publiés ou non, émanant des établissements d'enseignement et de recherche français ou étrangers, des laboratoires publics ou privés. 


\section{Accepted Manuscript}

Jurassic paleogeography of the Tian Shan: An evolution driven by far-field tectonics and climate

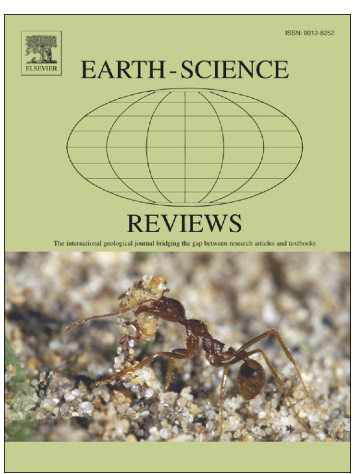

Julien Morin, Marc Jolivet, Cécile Robin, Gloria Heilbronn, Laurie Barrier, Sylvie Bourquin, Yingying Jia

PII: $\quad$ S0012-8252(18)30327-1

DOI: $\quad$ doi:10.1016/j.earscirev.2018.10.007

Reference: $\quad$ EARTH 2712

To appear in: $\quad$ Earth-Science Reviews

Received date: $\quad 25$ May 2018

Revised date: $\quad 4$ September 2018

Accepted date: $\quad 9$ October 2018

Please cite this article as: Julien Morin, Marc Jolivet, Cécile Robin, Gloria Heilbronn, Laurie Barrier, Sylvie Bourquin, Yingying Jia , Jurassic paleogeography of the Tian Shan: An evolution driven by far-field tectonics and climate. Earth (2018), doi:10.1016/ j.earscirev.2018.10.007

This is a PDF file of an unedited manuscript that has been accepted for publication. As a service to our customers we are providing this early version of the manuscript. The manuscript will undergo copyediting, typesetting, and review of the resulting proof before it is published in its final form. Please note that during the production process errors may be discovered which could affect the content, and all legal disclaimers that apply to the journal pertain. 
Julien Morin ${ }^{1}$, Marc Jolivet ${ }^{1}$, Cécile Robin ${ }^{1}$, Gloria Heilbronn ${ }^{2}$, Laurie Barrier ${ }^{3}$, Sylvie 5 Bourquin $^{1}$, Yingying $\mathrm{Jia}^{4}$

${ }^{1}$ Univ Rennes, CNRS, Géosciences Rennes, UMR 6118, CNRS - F-35000 Rennes, France.

2 CASP, West Building, Madingley Rise, Madingley Road, Cambridge, CB3 0UD, United

Kingdom.

${ }^{3}$ Institut de Physique du Globe de Paris, Sorbonne Paris Cité, Université Paris Diderot, UMR 7154 CNRS, Paris, France.

4 University of Chinese Academy of Sciences, No. 19A Yuquan Road, Beijing 100049, China.

\section{ABSTRACT}

The strongly intracontinental Tian Shan region, in Central Asia represents a key area to understand the long term evolution of continents in general and Asia in particular. If its Paleozoic and Cenozoic geodynamics are well understood, its Mesozoic evolution remains poorly constrained. In order to decipher the paleogeographic and large-scale tectonic evolution of the Tian Shan area during the Jurassic, we compiled, detailed field analyses of sedimentary rocks acquired within and around the Chinese Tian Shan region together with previously published data. We present three paleogeographical maps corresponding to the late Early - early Middle Jurassic, late Middle - early Late Jurassic and Late Jurassic - Early Cretaceous transition periods. We provide a large - scale picture of the Jurassic paleogeographic and climatic evolution of the Tian Shan region and discuss the geological 
evolution of the range together with the possible driving mechanisms. During the Early to early Middle Jurassic, the topographic evolution of the Tian Shan Range was dominated by progressive planation of late Paleozoic to early Mesozoic relief, locally interrupted by shortlived tectonic uplift. Throughout the region, contemporaneous sedimentation was characterized by alluvial to lacustrine strata deposited under humid conditions. During this period, recurrent limited deformation events associated with strike-slip and compressive tectonics occurred that cannot be explained by far field effect of the Qiangtang collision but could instead be associated to the coeval subduction-related extension affecting the Caspian Turan domains. During the late Middle to early Late Jurassic, the planation of the Paleozoic early Mesozoic Tian Shan Range then continued. A shift to more semi-arid conditions during the Late Jurassic is also recorded in the sedimentary series all over the region. At that time, few evidences of deformation exists in the Tian Shan or within the Caspian - Turan domains. We propose that the late Middle - early Late Jurassic corresponded to a period of relative tectonic quiescence in the area. Finally, the Late Jurassic - Early Cretaceous transition was marked by a tectonic reactivation leading to the inversion of the Yarkand - Fergana Basin and to localized relief building in the Tian Shan. This renewed transpressive deformation phase could be mainly related to the coeval accretion of the Helmand block to the south-west, and possibly to the onset of the accretion of the Lhasa Block along the southwestern margin of Eurasia. Finally, this period was also characterized by the climax of aridification which played a major role on the emplacement of extensive alluvial fan systems in the basins surrounding the range.

KEYWORDS: Jurassic, Tian Shan, Paleogeography, Climate, Tectonics 


\section{INTRODUCTION}

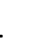

The long-term geodynamic evolution of Asia is characterized by a succession of orogenesis driven by accretion of continental blocks along the southern margin of the continent (e.g., Jolivet, 2017). These collisional orogenic events succeeded one another from the Paleozoic, with the final accretion of the Central Asian Orogenic Belt during the Permian (e.g., Windley et al., 2007; Wilhem et al., 2012), the Permian-Triassic Indosinian orogeny and the closure of the paleo-Tethys ocean (e.g., Roger et al., 2010, 2011), the Mesozoic accretion of the various blocs that form the Tibetan and South Caspian domains (e.g., Zonenshain and Le Pichon 1986; Thomas et al., 1999; Brunet et al., 2003), the Cretaceous closure of the Mongol-Okhotsk ocean in Siberia (e.g., Enkin et al., 1992; Zorin, 1999; Cogné et al., 2005; Jolivet et al., 2017b), and finally the Cenozoic collision of India (e.g., Allègre et al., 1984; Tapponnier et al,, 2001). These successive events bring the idea of a continent essentially affected by compressive deformation and largely characterized by the growth of large mountain ranges. Within this largely compressive geodynamic setting, the Jurassic period corresponds to a peculiar time span comprised between two major orogenic events: 1) the Cimmerian orogeny which began during the late Paleozoic and ended during the Triassic Jurassic transition (e.g., Sengör, 1979; Watson et al., 1987; Mattauer et al.1992; Roger et al., 2010; Metcalfe, 2013) and 2) the Cenozoic Himalayan orogeny (e.g., Molnar and Taponnier, 1975; Yin, 2009). During the Jurassic, the Eurasian continent was mostly surrounded by subduction zones leading to late Early - Middle Jurassic extension within the Caspian - Turan domains (e.g., Zonenshain and Le Pichon 1986; Nikishin et al. 1998; Thomas et al., 1999; Brunet et al., 2003, 2017; Robert et al., 2014; Mordvintsev et al., 2017) and to Late Jurassic Cretaceous extension within the Siberian - Mongolian domains (e.g., Zorin 1999; Graham et al., 2001; Johnson et al., 2004; Daoudene et al., 2009; Donskaya et al., 2008; Ritts et al. 2010). However, the Jurassic paleogeographic and kinematic evolution of the probable relay 
zone corresponding to the Tian Shan region in Central Asia is yet to be fully understood. Some studies indicate that during its Jurassic evolution, this area was dominated by progressive planation of the Tian Shan relief (Dumitru et al., 2001; Jolivet et al., 2010) while others propose that the region underwent recurrent periods of relief building (e.g., Allen et al., 1991; Hendrix et al., 1992; Yang et al., 2015). Recurrent tectonic activity did occur during that period but the kinematics and driving mechanisms of these events are highly debated. Some consider that the Tian Shan region was dominated by strike-slip and transtensive tectonics in a rather quiescent geodynamic setting (Jolivet et al., 2013) whereas others propose that the Tian Shan was rather under a compressional setting related to far-field collisions (e.g., Hendrix et al., 1992; Eberth et al, 2001; Vincent et al., 2001; Greene et al., 2001; Yang et al., 2013; Liu et al., 2013; Yang et al., 2015).

Finally, a Late Jurassic - Early Cretaceous tectonic reactivation has been recorded by low-temperature thermochronology data within the Kyrgyz Tian Shan, although to the east, in the Chinese Tian Shan, the same type of data only suggest slow cooling (Dumitru et al., 2001; Jolivet et al., 2010; De Grave et al,, 2007, 2012, 2013; Glorie and De Grave., 2016; Nachtergaele et al., 2018). At the same period, extensive alluvial fan systems have been deposited in several basins surrounding the Tian Shan Range. These alluvial fans were inferred to have been formed in response to renewed tectonic activity (Hendrix et al, 1992; Sobel et al., 1999; Vincent et al., 2001; Yang et al., 2015). Moreover, a rapid transition from humid conditions that prevailed during the Middle Triassic to Middle Jurassic to a semiarid/arid climate that developed during the Late Jurassic - Early Cretaceous period also occurred in the Tian Shan area (Hendrix et al., 1992; Eberth et al., 2001; Shao et al., 2003; Jolivet et al., 2017a). This change in climatic conditions is thought to have had a major impact on the paleogeographical evolution of this region by controlling the emplacement of the extensive Late Jurassic - Early Cretaceous alluvial fan systems (Jolivet et al., 2017a). However, available descriptions of the Jurassic paleogeography or tectonic evolution of the 
Tian Shan Range usually address too restricted areas and/or stratigraphic intervals to fully understand the impact of far-field deformation within this peculiar period in Central Asia history (e.g., Shao et al., 2003; Bian et al., 2010; Feng et al., 2015; Yang et al., 2015; Jolivet et al., 2017a; Gao et al., 2017).

Therefore, in order to better understand the paleogeographic and large-scale tectonic evolution of the Tian Shan area, we compiled, our own detailed field analyses of sedimentary rocks in various basins associated with the range and previously published data to construct three paleogeographic maps for the periods of to the late Early - early Middle Jurassic, late Middle- early Late Jurassic and Late Jurassic - Early Cretaceous transition. We provide a large - scale picture of the Jurassic paleogeographic and climatic evolution of the Tian Shan region and discuss the kinematic evolution of the range together with the possible driving mechanisms.

\section{GEOLOGICAL SETTING}

\section{1. LATE PALEOZOIC LITHOSPHERIC STRUCTURES AND MESO-CENOZOIC} REACTIVATIONS:

The lithospheric structure of the Tian Shan results from the late Paleozoic amalgamation of continental blocks and magmatic arcs along the southern margin of the Central Asian Orogenic Belt (CAOB; Sengör et al., 1993; Windley et al., 2007; Charvet et al., 2011; Alexeiev et al, 2017b). Subsequently, the Tian Shan Range underwent transpressive deformation during the Permian - Early Triassic in response to the oblique convergence between Siberia and Baltica (Bazhenov et al., 1999; Van der Voo et al., 2006). This induced dispersed rotations and motion along numerous strike-slip faults such as the Talas - Fergana fault, the Nikolaev line or the North Tian Shan fault (Fig. 1) (e.g., Allen et al., 1991; Laurent- 
Charvet et al., 2002; Buslov et al., 2004; Van der Voo et al, 2006 and references therein; Rolland et al., 2013). An alternative model proposed that counterclockwise rotation of the Yili - West Junggar blocks with respect to Tarim and Siberia induced large strike-strike slip motions along the previously mentioned lithospheric faults, resulting in about $1160 \pm 380 \mathrm{~km}$ lateral displacement in the Tian Shan belt (Wang et al., 2007a). Independently to the tectonic model, thermochronology data recorded a strong Permian-Triassic cooling- exhumation phase within the Tian Shan Range implying the build-up of a major topography during that period (Dumitru et al., 2001; Jolivet et al., 2010).

During the Meso-Cenozoic, the Paleozoic faults played a major role in localizing the deformation during the successive tectonic episodes that affected the Tian Shan Range (Allen et al., 1991, 2001; Hendrix et al., 1992; Sobel et al., 1999; Dumitru et al., 2001; Jolivet et al., 2010; Rolland et al., 2013; Alexeiev et al., 2017). From the Triassic to the Cretaceous, several accretion-collision events (generally known as the Cimmerian Orogeny) took place along the southern Eurasian margin including the collision of the Qiangtang (Late Triassic-Early Jurassic), Lhasa (Late Jurassic-Early Cretaceous) and the Kohistan-Ladakh (Late Cretaceous) blocks (Matte et al., 1996; Kapp et al., 2007; Roger et al., 2010). These events induced the reactivation of the Palaeozoic structures, which led to crustal deformation in the Tian Shan area (Hendrix et al., 1992; Allen et al., 2001; Dumitru et al., 2001; De Grave et al., 2007; Jolivet et al., 2010; Glorie and De Grave., 2016). Finally, tectonic reactivation related to farfield effects of the India-Asia collision initiated during the late Oligocene - Miocene and led to the growth of the present-day Tian Shan Range (e.g., Molnar and Taponnier, 1975; Thomas et al., 1999; Sobel et al., 1999; Macaulay et al., 2014; Jia et al., 2015). 


\section{2. LATE PALEOZOIC - EARLY CRETACEOUS EVOLUTION OF THE TIAN}

\section{SHAN SEDIMENTARY BASINS}

\section{2. 1. The Junggar Basin}

The Junggar (Fig. 1) is an intracontinental basin bordered by the Tian Shan Range to the south, the Halaalate mountains to the west, and the Altai Range to the north-east. This basin preserves, in its thickest part, around $16 \mathrm{~km}$ of late Paleozoic to Quaternary sediments. The formation of the Junggar Basin followed the southward subduction of the North Tian Shan Ocean underneath the Yili block and its subsequent Late Carboniferous - Early Permian closure (e.g.,Gao et al., 1998; Wang et al, 2006; Charvet et al., 2011). Depending on the authors, the Junggar Basin initiated either during the Late Carboniferous in a post-collisional extensional setting (Qiu et al., 2005; Yang et al., 2013; Liu et al., 2015) or during the Permian as a response to a transtensional tectonics (Allen et al., 1991) associated with magmatism (Carrol et al., 1995; Wang et al., 2009).

In this basin, the Upper Carboniferous strata consist of interbedded marine mudstone, siltstone and rare clayey limestone units followed upward by thick units of sandstone (Novikov, 2013). The Lower Permian then marks the end of marine sedimentation with the deposition of a regressive sequence representing the final retreat of the sea from the South Junggar and the onset of continental sedimentation (Carroll et al, 1990, 1995). The top of the Permian sequence consists of conglomerates, sandstones, siltstones and mudstones interpreted as alluvial plain and lacustrine deposits (Carroll et al., 1995; Bian et al., 2010; Yang et al., 2013).

During the Triassic, the Junggar Basin evolved either as a foreland basin (Hendrix et al., 1992; Bian et al., 2010) or as a transtensional basin (Allen et al., 1995). Lower and Middle Triassic units consist of conglomerates, sandstones and red to brown siltstones typical of 
continental sediments deposited in alluvial fan and alluvial plain environments. They are locally associated to caliche beds indicating deposition in seasonal semi-arid to arid conditions (Hendrix et al., 1992; Bian and al., 2010; Nivokov, 2013). Finally, the Upper Triassic sedimentary rocks consist of interbedded conglomerates, sandstones and grey siltstones interpreted as deposited in alluvial fan to alluvial plain environments under humid conditions (Hendrix et al., 1992; Ashraf et al., 2010; Bian et al., 2010; Nivokov, 2013). Subsequently, the Junggar Basin is thought to have evolved either as a flexural depression (Bian et al., 2010; Yang et al,, 2012; Feng et al, 2015) or as a transpressional basin (Dengfa et al., 2008; Gao et al., 2017) during the Jurassic period. The contemporaneous conglomeratic to sandy and silty deposits are mainly related to alluvial to lacustrine environments (Hendrix et al., 1992; Eberth et al., 2001; Bian et al., 2010; Feng et al., 2015; Yang et al., 2015). The occurrence of widespread coal deposits in the Lower to Middle Jurassic series suggests humid conditions (e.g., Hendrix et al, 1992; Eberth et al., 2001; Vincent et al, 2001). Upper Jurassic series are then characterized by the disappearance of coal and by the formation of calcareous paleosols indicative of semi-arid conditions (Hendrix et al., 1992; Eberth et al., 2001; Vincent et al., 2001; Jolivet et al, 2017a). Finally, the Jurassic-Cretaceous transition is characterized by the emplacement of well-developed conglomerates thought either to mark a tectonic reactivation of the Tian Shan Range (Hendrix et al, 1992; Yang et al., 2015) or to be mostly driven by climate (Jolivet et al, 2017a).

\section{2. 2. The intra-mountain basins}

Several intra-mountain basins such as the Yili, Bayanbulak, and Turfan basins are preserved within the interior of the Tian Shan Range (Fig. 1). They formed concurrently to the Junggar Basin and are associated to the same late Paleozoic post-orogenic phase of extensive 
or transtensive deformation (Wang et al., 2006, 2009; Charvet et al., 2007; Jolivet et al., 2010; Xia et al., 2012).

The Yili Basin is bordered by the Borohoro Range (North Tian Shan) to the north and by the Narat Range (South Tian Shan) to the south. In its thickest part, this basin preserves around $5 \mathrm{~km}$ of Permian to Quaternary sediments. Its Permian series consist of marine sediments followed by the emplacement of volcanics and volcanoclastics deposits during the Upper Permian ( $\mathrm{Li}$ et al., 2015). These series are uncomformably overlaid by the Triassic sediments, implying tectonic deformation at least up to the Lower Triassic (Li et al., 2015). Jurassic series consist of alluvial, lacustrine delta and lake deposits containing extensive coal beds that indicate humid conditions ( $\mathrm{Li}$ et al., 2014). However this basin does not contain Upper Jurassic - Lower Cretaceous sediments (AGMCA, 2008).

The Bayanbulak Basin is located between the Narat Range to the north, the South Tian Shan Range to the south, and the Erbin Shan Range to the east. It preserves Mesozoic and Cenozoic sediments but its late Paleozoic to Mesozoic evolution is poorly known.

The Turfan Basin is a flexural basin containing in its deepest part around $7 \mathrm{~km}$ of Permian to Quaternary sediments (Shao et al., 1999). It is located between the Bogda ShanBarkhol Tagh ranges to the north and the Chöl Tagh mountain range to the south. Its Lower Permian strata consist of continental and marine deposits interbedded with volcanic and volcanoclastic series (Shao et al., 1999; Wartes et al, 2002). During the Late Permian - Early Cretaceous, the Turfan Basin then evolved as a compressive basin (Hendrix et al., 1992; Allen et al., 1993; Shao et al., 1999; Wartes et al., 2002). Its Upper Permian to Early Cretaceous series are entirely continental and consist of alluvial to lacustrine deposits (Hendrix et al., 1992; Shao et al., 1999; Greene et al., 2001; Wartes et al., 2002).

In the Kyrgyz Tian Shan, the Issyk-Kul, Naryn, Aksai and Ming-Kush basins are intramountain depressions containing Jurassic to Quaternary sediments (Fig. 1) (Lasovskiy and Mozolev, 1961; VNIGNI and Beicip Franlab, 1992; Macaulay et al., 2014; De Pelsmaeker et 
231 al., 2018). In the Issyk-Kul Basin, these sedimentary rocks consist mainly of alluvial to

232 shallow lacustrine deposits containing numerous coal beds and plant fragments indicating 233 humid conditions but they also contain caliche - type paleosols more typical of semi-arid 234 conditions (De Pelsmaeker et al, 2018). The Ming-Kush Basin is a narrow transpressive 235 depression containing 100-680m thick Jurassic deposits resting unconformably on Paleozoic basement rocks (Lasovskiy and Mozolev, 1961; De Pelsmaeker et al., 2018). They mainly consist of alluvial plain, fan delta and shallow lacustrine deposits associated with coal-rich layers and plant fragments indicating humid conditions (Lasovskiy and Mozolev, 1961; De

Pelsmaeker et al., 2018). Finally, Jurassic sedimentary rocks consisting mainly of coalbearing continental deposits resting unconformably on Paleozoic rocks occur in both the Naryn and Aksai basins (VNIGNI and Beicip Franlab, 1992; AGMCA, 2008).

\section{2. 3. The Tarim Basin}

The Tarim Basin (Fig. 1) is a large intracontinental basin located between the Tian

Shan to the north, and the Western Kunlun and Altyn Tagh ranges to the south. In its thickest part, it contains up to $16 \mathrm{~km}$ of Late Precambrian to Quaternary sediments. This basin underwent multiple phases of tectonic deformation since the Late Precambrian (Desheng et al, 1996). The Tarim craton accreted to the Kazakhstan-Yili terrane in the Late

Carboniferous-Early Permian during the final amalgamation of the CAOB and the closure of the South Tian Shan Ocean (Carroll et al., 1995; Chen et al., 1999; Liu et al., 2014; Alexeiev et al., 2015). During that period, the Tarim Basin evolved as a compressive basin with Upper Carboniferous to Lower Permian series consisting of marine limestones, volcanoclastics and continental conglomerates, sandstones and siltstones (Caroll et al., 1995; Lin et al., 2012). a LIP province within the basin (Carroll et al., 1995; Qin et al., 2011; Yu et al., 2011). 
During the Mesozoic, the Tarim Basin finally seems to evolve again as a compressive

258

259

260

261

262 basin in its northern and eastern parts (Desheng et al., 1996), with Triassic, Jurassic and Early Cretaceous depositional systems consisting of alluvial plain to lacustrine environments (Desheng et al., 1996; Hendrix et al., 1992). However, there are no Mesozoic deposits to the south-west of the basin, except along the Pamir-Western Kunlun Range, where Jurassic deposits are interpreted to have been deposited in pull-apart basins (Sobel et al., 1999).

\section{2. 4. The Fergana Basin}

The Fergana Basin is an intracontinental basin situated to the west of the Kyrgyz Tian Shan. It is surrounded by the Chatkal and Kurama ranges to the north, the Fergana Range to the east and by the Alai Range to the south (Fig. 1). In its thickest part, it contains around 10 $\mathrm{km}$ of Permian to Quaternary sediments.

Following the late Paleozoic building of the ancestral Tian Shan, post-orogenic Upper Permian to Lower Triassic alluvial to lacustrine sediments were deposited (Clarke, 1984; Moisan et al, 2011). The basin was then subsequently inverted leading to a Middle - Late Triassic erosional event (Clarke, 1984; Bande et al., 2015). Renewed subsidence started from the Early Jurassic and led to the accumulation of alluvial to lacustrine deposits during the Jurassic and Early Cretaceous (Clarke, 1984; Jolivet et al., 2017a; De Pelsmaeker et al., 2018).

\section{2. 5. The Yarkand - Fergana Basin}

$$
\text { The Yarkand - Fergana Basin is described as a transtensional pull-apart basin located }
$$
along the south-western termination of the Talas Fergana/Karatau fault (Fig. 1) (Sobel et al., 1999; Allen et al, 2001; Alexeiev et al., 2017; De Pelsmaeker et al., 2018). The sedimentary 
thickness progressively decreases away from the fault where up to $5 \mathrm{~km}$ of Jurassic sediments were deposited (Sobel et al., 1999; De Pelsmaeker et al., 2018). Lower to Middle Jurassic sediments consist mainly of alluvial, fan delta and deep lake deposits containing coal beds and plant fragments indicating humid conditions (Sobel et al., 1999; De Pelsmaeker et al., 2018). To the south of the basin, in the north-western Tarim region, the Upper Jurassic - Lower Cretaceous transition consists in up to $400 \mathrm{~m}$-thick conglomeratic fluvial channel systems subsequently followed by Lower Cretaceous deposits characterized by fluvial red beds (Sobel et al., 1999).

\section{SEDIMENTOLOGICAL ANALYSES}

\section{1. METHODS AND AGE CONSTRAINTS}

In this study we present new sedimentological data from Upper Triassic to Lower Cretaceous sedimentary units from the south Junggar, north Tarim, Yili and Bayanbulak basins (Fig. 1; see Appendix A for GPS coordinates of analyzed sections). Detailed analyses of field $\operatorname{logs}(1 / 1000$ scale), sedimentary facies, trace fossils and paleosols were performed on each of the seven sections presented below with the objective of reconstructing the depositional environment evolution through time.

To establish the first order age intervals in the sediment sequences and assess the corresponding formation names (Fig. 2; lithostratigraphy from Hendrix et al., 1992), we relied on geological maps (XBGMR, 1969, 1970, 1973 a, b, 1978 a, b), published ages derived from biostratigraphical analyses and sporopollen assemblages (for more references see Hendrix et al., 1992; Deng et al., 2010) and published lithological descriptions (Hendrix et al., 1992; 


\section{2. FACIES MODEL AND DEPOSITIONAL ENVIRONMENTS}

In the seven sections described below, twelve facies assemblages were defined based on lithology and sedimentary structures before being interpreted in terms of depositional processes (Table. 1). Together with those facies, five different pedogenic and alteration features were also identified (Table. 2). All these facies, pedogenic and alteration features were subsequently associated and interpreted in terms of depositional environments (Table. 3). Climatic conditions were inferred from these sedimentological analyses. In total, 10 environments ranging from alluvial fan to lake, evolving in both humid and semi-arid/arid conditions have been defined. 3D diagrams have been constructed to illustrate the general organization of each proposed depositional environment (Table. 3).

However, some morphological variability exists within those environments, especially for the lacustrine delta systems. Indeed, lithologies and sedimentary structures vary depending on the sections and are, for example, characteristic of different flow regimes. For the purpose of this paper we decided to group these more specific morphologies within one general environment associated with a global architecture (i. e. lacustrine delta (LD), Table. 3).

Table. 1: Summary of the facies characteristics within the Chinese Jurassic Tian Shan and 


\begin{tabular}{|c|c|c|c|}
\hline $\begin{array}{l}\text { Facies } \\
\text { code }\end{array}$ & Lithology & Sedimentary structures & $\begin{array}{l}\text { Inferred depositional } \\
\text { processes }\end{array}$ \\
\hline \multicolumn{4}{|c|}{ Miscellaneous } \\
\hline F1 & a cm- to dm- thick coal beds & $\begin{array}{l}\text { Tabular beds containing } \\
\text { plant remains }\end{array}$ & Peat accumulation \\
\hline $\mathbf{F 2}$ & $\begin{array}{l}\text { Several } \mathrm{cm} \text { - to dm- thick } \\
\text { white tuffaceous beds }\end{array}$ & Massive & $\begin{array}{l}\text { Subaerial volcanic ash } \\
\text { deposition }\end{array}$ \\
\hline \multicolumn{4}{|c|}{ Calcareous facies } \\
\hline $\mathbf{F 3}$ & $\begin{array}{l}\text { a cm- to dm- thick siltstones } \\
\text { interbedded with a cm- to } \\
\text { dm- thick calcareous beds }\end{array}$ & $\begin{array}{l}\text { Massive to flat-laminated } \\
\text { siltstone layers alternating } \\
\text { with tabular calcareous } \\
\text { beds with occasionally } \\
\text { medium to strong } \\
\text { bioturbation }\end{array}$ & $\begin{array}{l}\text { Deposition from } \\
\text { suspension fallout } \\
\text { alternating with } \\
\text { episodes of calcareous } \\
\text { production }\end{array}$ \\
\hline \multicolumn{4}{|c|}{ Heterolithic facies } \\
\hline $\mathbf{F 4}$ & $\begin{array}{l}\text { a } \mathrm{m} \text { - to } \mathrm{m} \text { - thick siltstones } \\
\text { containing } \mathrm{cm} \text { - to dm- thick } \\
\text { fine- to medium-grained } \\
\text { sandstones }\end{array}$ & $\begin{array}{l}\text { - Massive or flat laminated } \\
\text { siltstones sometimes } \\
\text { containing desiccation } \\
\text { cracks or bioturbation } \\
\text { - Tabular sandstone beds } \\
\text { with sharp basal } \\
\text { boundaries containing } \\
\text { current ripples and } \\
\text { sometimes bioturbation }\end{array}$ & $\begin{array}{l}\text { - Deposition from } \\
\text { suspension fallout with } \\
\text { some emergent events } \\
\text { - Tractional current } \\
\text { deposition (low energy } \\
\text { flows; Miall 1978) with } \\
\text { occasional periods of } \\
\text { subaqueous biological } \\
\text { reworking }\end{array}$ \\
\hline F5 & $\begin{array}{l}\text { heterolithic facies composed } \\
\text { of } \mathrm{cm} \text { - to dm-thick siltstones } \\
\text { interbedded with } \mathrm{cm} \text { - to dm- } \\
\text { thick fine to medium (rarely } \\
\text { coarse) grained sandstone }\end{array}$ & $\begin{array}{l}\text { Flat laminated siltstone } \\
\text { beds alternating with } \\
\text { tabular sandstone beds } \\
\text { containing current, } \\
\text { climbing and/or oscillatory } \\
\text { ripples; cm-scale soft } \\
\text { sediment deformation } \\
\text { structures, slightly to } \\
\text { moderately bioturbated }\end{array}$ & $\begin{array}{l}\text { Deposition from } \\
\text { suspension fallout } \\
\text { alternating with } \\
\text { overbanks and waning } \\
\text { floods, turbidity currents } \\
\text { within a permanent } \\
\text { water body (Mulder and } \\
\text { Alexander, 2001). } \\
\text { Deposition or reworking } \\
\text { by waves and biological } \\
\text { activity }\end{array}$ \\
\hline F6 & $\begin{array}{l}\mathrm{cm}-\text { to dm- thick siltstones } \\
\text { alternating with } \mathrm{cm} \text { - to dm- } \\
\text { thick beds of fine- to coarse- } \\
\text { grained sandstones }\end{array}$ & $\begin{array}{l}\text { Massive to flat-laminated } \\
\text { siltstone beds alternating } \\
\text { with sandstone beds either } \\
\text { - Tabular containing flat } \\
\text { laminations, occasional } \\
\text { current and climbing } \\
\text { ripples. Occasional plant } \\
\text { fragments or } \\
\text { - Lenticular and massive } \\
\text { with erosional basal } \\
\text { boundaries with } \\
\text { occasional rip-up mud } \\
\text { clasts and plant fragments }\end{array}$ & $\begin{array}{l}\text { Deposition from } \\
\text { suspension fallout } \\
\text { alternating with } \\
\text { overbanks, waning flood } \\
\text { currents or from } \\
\text { tractional currents under } \\
\text { stream flows (Miall, } \\
\text { 1978) }\end{array}$ \\
\hline
\end{tabular}




\begin{tabular}{|c|c|c|c|}
\hline \multicolumn{4}{|c|}{ Sandstone facies } \\
\hline F7 & $\begin{array}{l}\text { Stacked to isolated dm- to } \\
\mathrm{m} \text { - thick medium to coarse } \\
\text { grained sandstones }\end{array}$ & $\begin{array}{l}\text { Tabular to slightly } \\
\text { lenticular beds with sharp } \\
\text { or low erosional basal } \\
\text { boundaries. Trough cross- } \\
\text { beddings, flat beddings } \\
\text { underlined by rip-up clasts } \\
\text { and sometimes with } \\
\text { current ripples at the top } \\
\text { of the beds. Occasional } \\
\text { burrows }\end{array}$ & $\begin{array}{l}\text { 3D megaripples or } \\
\text { planar beds of tractional } \\
\text { currents deposits under } \\
\text { subaerial or subaqueous } \\
\text { sheet flows and stream } \\
\text { flows (Miall, 1978) }\end{array}$ \\
\hline F8 & $\begin{array}{l}\text { a } \mathrm{m} \text { - to } \mathrm{m} \text {-thick fine-grained } \\
\text { to gravelly sandstones }\end{array}$ & $\begin{array}{l}\text { Slightly to strongly } \\
\text { lenticular beds with } \\
\text { erosional basal } \\
\text { boundaries. Trough cross- } \\
\text { stratifications or flat } \\
\text { beddings (highlighted by } \\
\text { gravels, coal and mud } \\
\text { clasts) and current ripples; } \\
\text { a dm- to a m- scale fining- } \\
\text { up trends }\end{array}$ & $\begin{array}{l}\text { 3D megaripples, planar } \\
\text { beds of tractional } \\
\text { currents deposits under } \\
\text { subaerial stream flows } \\
\text { (Miall, 1978) }\end{array}$ \\
\hline F9 & $\begin{array}{l}\text { dm- to m- thick, stacked } \\
\text { medium-grained to gravelly } \\
\text { well-sorted, sandstones }\end{array}$ & $\begin{array}{l}\text { Tabular beds with sharp } \\
\text { basal boundaries. Flat- } \\
\text { beddings, trough and } \\
\text { planar cross stratification, } \\
\text { sigmoidal beddings } \\
\text { highlighted by gravels, } \\
\text { coal and mud clasts and } \\
\text { occasional current ripples; } \\
\text { a dm- to dm scale } \\
\text { dewatering structures and } \\
\text { soft sediment deformation }\end{array}$ & $\begin{array}{l}\text { Tractional currents with } \\
\text { planar beds, 2D and 3D } \\
\text { megaripples under } \\
\text { subaqueous sheet flows } \\
\text { (Miall, 1978) and with } \\
\text { some gravitational } \\
\text { events }\end{array}$ \\
\hline F10 & $\begin{array}{l}\text { a } \mathrm{m} \text { - to } \mathrm{m} \text { - thick fine- to } \\
\text { coarse- grained sandstones, } \\
\text { well- to moderately well- } \\
\text { sorted }\end{array}$ & $\begin{array}{l}\text { m- to a dcm- high foreset } \\
\text { composed of grainfalls } \\
\text { and inverse climbing } \\
\text { ripple. } \\
\text { Horizontal laminations or } \\
\text { very low angle mm- scale } \\
\text { cross-laminations with } \\
\text { inverse climbing ripples. } \\
\text { Irregular mm horizontal } \\
\text { lamination with adhesion } \\
\text { warts and ripples }\end{array}$ & $\begin{array}{l}\text { Aeolian dune and } \\
\text { traction deposition by } \\
\text { high wind velocity or } \\
\text { migration of wind } \\
\text { ripples (Hunter 1977). } \\
\text { Wind-blown sand to a } \\
\text { wet surface (Kocurek } \\
\text { and Nielsen, 1986) }\end{array}$ \\
\hline & te facies & & \\
\hline
\end{tabular}




\begin{tabular}{|c|c|c|c|}
\hline F11 & $\begin{array}{l}\text { dm- to m- thick clast- } \\
\text { supported conglomerates } \\
\text { with poorly- to moderately- } \\
\text { sorted subangular to } \\
\text { subrounded pebbles to } \\
\text { boulders alternating with cm } \\
\text { to m-thick medium to coarse } \\
\text { grained sandstones } \\
\text { containing floating gravels }\end{array}$ & $\begin{array}{l}\text { Massive conglomerates } \\
\text { with erosive or sharp basal } \\
\text { boundaries and occasional } \\
\text { pebble imbrications } \\
\text { alternating with tabular or } \\
\text { lenticular sandstones, } \\
\text { structurless or with planar } \\
\text { laminations and trough } \\
\text { cross-bedding }\end{array}$ & $\begin{array}{l}\text { Hyperconcentrated } \\
\text { flows (Svendsen et al, } \\
\text { 2003) alternating with } \\
\text { 3D megaripple deposits } \\
\text { under sheet flows or } \\
\text { stream flows (Miall, } \\
\text { 1978) }\end{array}$ \\
\hline F12 & $\begin{array}{l}\text { a dm- to m- thick planar } \\
\text { couplets of mostly poorly- } \\
\text { sorted conglomerates, } \\
\text { angular to sub-angular } \\
\text { gravels to boulder, and of } \\
\text { poorly- to well-sorted sand }\end{array}$ & $\begin{array}{l}\text { Horizontal to sub- } \\
\text { horizontal bedded } \\
\text { conglomerates and } \\
\text { sandstones with erosive or } \\
\text { sharp basal boundaries. } \\
\text { Sometimes dm to m-thick } \\
\text { channelled bed }\end{array}$ & $\begin{array}{l}\text { Sediment-charged flash } \\
\text { floods due to either } \\
\text { seasonal or irregular } \\
\text { rainfalls (e.g., Blair and } \\
\text { McPherson, 1994). } \\
\text { Occasional sheet flow } \\
\text { and stream flow } \\
\text { deposits (Miall, 1978) }\end{array}$ \\
\hline F13 & $\begin{array}{l}\text { a m- to pluri m-thick } \\
\text { conglomerates with } \\
\text { subangular to subrounded } \\
\text { pebbles to boulders, poorly- } \\
\text { sorted, matrix-supported } \\
\text { (sand-rich) }\end{array}$ & $\begin{array}{l}\text { Massive, sometimes with } \\
\text { faint horizontal } \\
\text { laminations. Erosive or } \\
\text { sharp basal boundaries }\end{array}$ & $\begin{array}{l}\text { Gravity flow processes, } \\
\text { Debris flows (Postma, } \\
\text { 1990; Miall 1996) }\end{array}$ \\
\hline
\end{tabular}

Table. 2: Description and interpretation of pedogenic and alteration features

\begin{tabular}{|c|c|c|}
\hline $\begin{array}{l}\text { Facies } \\
\text { code }\end{array}$ & Lithology & Interpretations \\
\hline $\mathbf{P 1}$ & $\begin{array}{l}\text { Closely spaced, disconnected thin vertical root } \\
\text { traces, mm in thickness and a few cm-long within } \\
\text { siltstones to fine grained sandstones }\end{array}$ & Paleosols (Retallack, 1988) \\
\hline$\overline{\mathbf{P 2}}$ & $\begin{array}{l}\text { Sparse vertical roots, } \mathrm{mm} \text { wide, a few } \mathrm{cm} \text { to } \mathrm{dm}- \\
\text { long within sandstones }\end{array}$ & $\begin{array}{l}\text { Patchy and discontinuous } \\
\text { vegetation typical of dry } \\
\text { climate conditions (e.g., } \\
\text { Hasiotis et al., 2007) }\end{array}$ \\
\hline $\mathbf{P 3}$ & $\begin{array}{l}\text { Siltstone and sandstone facies modified by } \\
\text { marmorisation processes }\end{array}$ & $\begin{array}{l}\text { Pseudo-hydromorphic } \\
\text { palaeovertisoils, wet-dry } \\
\text { climate (Kraus, 1999; Klappa, } \\
\text { 1980; Hasiotis et al., 2007) }\end{array}$ \\
\hline $\mathbf{P 4}$ & $\begin{array}{l}\text { Dispersed to coalescent calcareous nodules, a cm- } \\
\text { to several } \mathrm{cm} \text { in diameter within siltstones to fine } \\
\text { grained sandstones }\end{array}$ & $\begin{array}{l}\text { Semi-arid pedogenic processes } \\
\text { indicative of seasonality (wet- } \\
\text { dry conditions; e.g., Retallack, } \\
\text { 1988; Hasiotis et al., 2007) }\end{array}$ \\
\hline $\mathbf{P 5}$ & $\begin{array}{l}\text { m- to several m- thick calcareous } \\
\text { impregnation/cementation within conglomerates }\end{array}$ & $\begin{array}{l}\text { Long-lasting wet/dry pedogenic } \\
\text { processes within semi-arid } \\
\text { environment (e.g., Retallack, } \\
\text { 1988; 2008) }\end{array}$ \\
\hline
\end{tabular}


Table. 3: Summary of the characteristics of the associated facies and their interpretations in

terms of depositional environments.

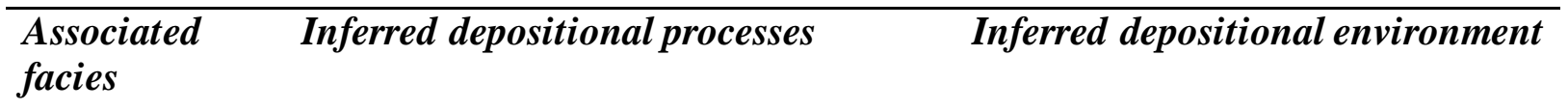

AF - F11, F13 Debris flow + hyperconcentrated flows + sheet flows and stream flows
Alluvial fan environment (e.g., Blair and McPherson, 1994)

AFa - P2, Flash floods +debris flows + F11, F12, F13 hyperconcentrated flows + occasional sheet flows and stream flows + desiccation cracks and root traces typical of dry climates

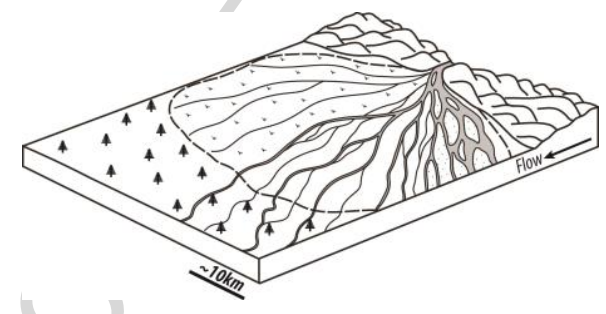

Alluvial fan environment in semi-arid to arid conditions dominated by ephemeral flows (e.g., Blair and McPherson, 1994; Mather \& Hartley 2005 )

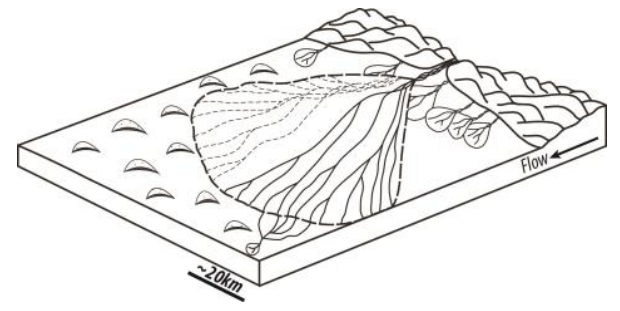

\begin{tabular}{lll}
\hline AP1 - F8, & $\begin{array}{l}\text { Subaerial sheet and stream flows }+ \\
\text { hyperconcentrated flows }\end{array}$ & $\begin{array}{l}\text { Proximal alluvial plain } \\
\text { environment with gravelly } \\
\text { alluvial deposits, probably } \\
\text { sometimes }\end{array}$ \\
$\begin{array}{l}\text { with coal } \\
\text { chastacteristic of a low sinuosity } \\
\text { bedload-dominated river system } \\
\text { plant }\end{array}$ & $\begin{array}{l}\text { (e.g., Miall 1996) } \\
\text { fragments } \\
\text { within F8 }\end{array}$
\end{tabular}


AP1a - P4, Same as AP1 but with pedogenic F8, F11, (F7) calcareous nodules
Proximal alluvial plain environment with gravelly alluvial deposits, probably characteristic of a low sinuosity bedload-dominated river system (e.g., Miall 1996) in semi-arid conditions (carbonate nodules: Hasiotis 2006; Hasiotis et al., 2007)

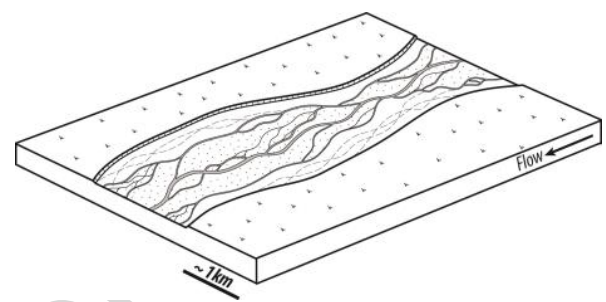

AP2 - P1, P3, Peat accumulation + root traces + F1, F6, F7, F8 suspension fallout + overbank and waning flood currents + subaerial and subaqueous sheet and stream flows

\begin{tabular}{lll}
\hline AP2a $-\mathrm{P} 4$, & $\begin{array}{l}\text { Same as AP2 but without peat } \\
\text { accumulation and with pedogenic } \\
\text { calcareous nodules }\end{array}$ & $\begin{array}{l}\text { Distal alluvial plain environment } \\
\text { with sandy alluvial deposits within } \\
\text { floodplains and/or swamps in } \\
\text { semi-arid conditions (carbonate } \\
\text { nodules: Hasiotis 2006; Hasiotis et } \\
\text { al., 2007) }\end{array}$ \\
\hline EG - F10 & $\begin{array}{ll}\text { Traction deposition by high velocity } \\
\text { wind velocity or migration of wind } \\
\text { ripples + wind-blown sand to a wet } \\
\text { surface }\end{array}$ & $\begin{array}{l}\text { Erg deposits with preservation of } \\
\text { large and thick aeolian dunes (up } \\
\text { interdunes deposits }\end{array}$ \\
\hline
\end{tabular}

Distal alluvial plain environment with sandy alluvial deposits within floodplains and/or swamps

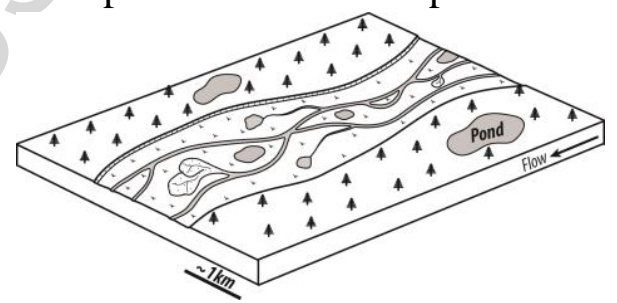
with sandy alluvial deposits within floodplains and/or swamps in semi-arid conditions (carbonate nodules: Hasiotis 2006; Hasiotis et al., 2007)

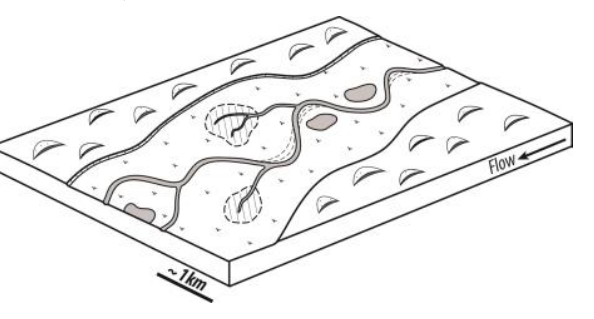

rg deposits with preservation of arge and thick aeolian dunes (up to $50 \mathrm{~m}$ in thickness) and surface interdunes deposits 


\begin{tabular}{|c|c|c|}
\hline $\begin{array}{l}\text { LD - P1, F1, } \\
\text { F4, } \\
\text { F5, F7, F9 }\end{array}$ & $\begin{array}{l}\text { Possible peat accumulation + root } \\
\text { traces }+ \text { overbank or waning floods }+ \\
\text { subaqueous sheet flows }+ \text { turbidity } \\
\text { currents and suspension fallout within } \\
\text { a permanent water body }+ \text { deposition } \\
\text { or reworking by waves + biological } \\
\text { reworking }\end{array}$ & $\begin{array}{l}\text { Lacustrine delta environment } \\
\text { with mouth bars and distal alluvial } \\
\text { deposits (ie unconfined flows) } \\
\text { within lakes }\end{array}$ \\
\hline $\begin{array}{l}\text { LE1 - F3, F4, } \\
\text { F5 }\end{array}$ & $\begin{array}{l}\text { Subaqueous suspension fallout }+ \\
\text { occasional calcareous production }+ \\
\text { waning floods and turbidity currents } \\
\text { within a permanent water body }+ \\
\text { deposition or reworking by waves }+ \\
\text { biological reworking }\end{array}$ & $\begin{array}{l}\text { Lacustrine environment with } \\
\text { some episodes of fluvial input }\end{array}$ \\
\hline $\begin{array}{l}\text { LE1a - P4, } \\
\text { F3, F4, F5, F7 }\end{array}$ & $\begin{array}{l}\text { Same as LE1 but with desiccation } \\
\text { cracks and pedogenic calcareous } \\
\text { nodules }\end{array}$ & $\begin{array}{l}\text { Shallow or playa lake } \\
\text { environment with frequent } \\
\text { emergence (desiccation cracks) } \\
\text { and episodes of fluvial input in } \\
\text { semi-arid conditions (carbonate } \\
\text { nodules: Hasiotis 2006; Hasiotis et } \\
\text { al., 2007) }\end{array}$ \\
\hline
\end{tabular}

3. 3. THE JURASSIC DEPOSITIONAL ENVIRONMENT EVOLUTION OF THE CHINESE TIAN SHAN

\section{3. 1. The south Junggar Basin}

\section{3. 1. 1. South Toutunhe section}

The South Toutunhe section (Fig. 6) is located in the south Junggar Basin, along the

Toutun River on the northern flank of the Tian Shan Range and more precisely to the south of

Kalaza fms), and Lower Cretaceous (Qingshuihe Fm) deposits (XBGMR, 1978b). 
The basal part of the logged Toutunhe Fm consists of distal alluvial plain deposits

353

354

355

356

357

358

359

360

361

362

363

364

365

366

367

368

369

370

371

372

373

374

375

376

377

associated to coal beds indicative of rather humid conditions (AP2) (Table. 3), which pass upward, in the last $230 \mathrm{~m}$ of the formation to lacustrine delta deposits (LD) (Fig. 6; Appendix B. 1). The transition with the Qigu Fm is progressive with deposits still characteristic of a lacustrine delta environment (LD) in the first $310 \mathrm{~m}$ of this formation. The next $90 \mathrm{~m}$ consist of distal alluvial plain deposits containing carbonate nodules indicative of semi-arid climate conditions (AP2a; Fig. 6). The Qigu Fm then evolves up section towards lacustrine delta sediments (LD) to finally ends with proximal alluvial plain deposits (AP1). The boundary with the $\sim 190$ m-thick Kalaza Fm is sharp and marks a sharp change in depositional environments (Fig. 6; Appendix B. 3). Indeed, the lower part of the Kalaza Fm is composed of a $50-70$ m-thick unit interpreted as erg deposits (EG) alternating with $\sim 40$ m thick units of alluvial fan sediments (AFa) (Appendix B. 4) (for more details see Jolivet et al., 2017a). This erg confirms the aridification trend already observed between the Toutunhe and Qigu formations. The basal part of the Lower Cretaceous Qingshuihe Fm shows a retrogradation towards a lake environment (LE1) (Fig. 6; Appendix B. 5).

\section{3. 1. 2. North Toutunhe section}

The North Toutunhe section (Fig. 7) is also located along the Toutun River, to the north of the Toutun dam (Fig. 1; Appendix $\mathrm{C}$ for a general overview of the section) and presents $\sim 1650 \mathrm{~m}$ of deposits ranging from Late Jurassic (Qigu and Kalaza fms) to Early Cretaceous (Qingshuihe Fm) in age (XBGMR, 1978b).

The first $655 \mathrm{~m}$ of the logged Qigu Fm consists of interbedded red siltstones and sandstones interpreted as lacustrine delta deposits (LD) evolving in the last $145 \mathrm{~m}$ of the formation towards distal alluvial plain sediments containing carbonate nodules and desiccation cracks indicative of semi-arid conditions (AP2a) (Fig. 7; Appendix C. 1,2) . As in 
the South Toutunhe section, the boundary between the upper Qigu Fm and the Kalaza Fm is

379 sharp and corresponds to an abrupt change in depositional environments (Appendix C. 3).

380 Indeed the Kalaza Fm ( 740 m thick) consists of large aeolian dunes (preserved dune sets are

381

382 up to $50 \mathrm{~m}$ in thickness) and interdune deposits characteristic of erg systems (EG) (Fig. 7). The basal part of the Lower Cretaceous Qingshuihe Fm shows a drastic change in environments with the emplacement of sediments indicative of lacustrine delta (LD) followed by lacustrine deposits (LE1) dominated by fine - grained facies.

\section{3. 1. 3. The Manas section}

The 5510 m-thick Manas section (Fig. 8), located in the south Junggar Basin, along the Manas River on the northern flank of the Tian Shan Range (Fig. 1; Appendix D for general pictures of the section) encompasses Upper Triassic, Lower Jurassic (Badaowan and Sangonghe fms), Middle Jurassic (Xishanyao and Toutunhe fms), Upper Jurassic (Qigu and Kalaza fms) and Lower Cretaceous (Qingshuihe Fm) deposits (XBGMR, 1978a; Hendrix et al., 1992; Eberth et al., 2001; Deng et al., 2010).

The upper part of the Triassic succession (only the topmost $\sim 200 \mathrm{~m}$ were logged in this work) displays distal alluvial plain (AP2) and lacustrine delta environments (LD) evolving towards alluvial fan systems (AF) (Fig. 8). The first $780 \mathrm{~m}$ of the Lower Jurassic series (Badaowan Fm) consists of an alternation of distal alluvial plain (AP2) and alluvial fan (AF) deposits. The latter are dominated by clast-supported conglomerates with sub-rounded pebbles, occasionally associated with coal beds, which suggest rather humid conditions (AF) (Fig. 8; Appendix D. 1). These deposits pass upwards in a retrogradational trend into sediments indicative of a lacustrine delta environment (LD). Above, the top $400 \mathrm{~m}$ of the Lower Jurassic series correspond to the Sangonghe Fm, which is characterized by a progradational trend towards a proximal alluvial plain system (AP1) followed by a 
retrogradational trend with depositional environments evolving from a proximal to a more distal alluvial plain (AP1, AP2) and finally to a lacustrine delta (LD).

The Middle Jurassic Xishanyao Fm ( 1705 m thick; Appendix D. 2) then comprises a poorly exposed basal series (570 $\mathrm{m}$ thick) showing a progradational trend from lacustrine delta (LD) to proximal alluvial plain (AP1) deposits. The topmost $1135 \mathrm{~m}$ of this formation show a retrogradational trend with environments evolving towards a distal alluvial plain (AP2) and a lacustrine delta (LD) associated with the presence of numerous coal beds indicative of rather humid climate conditions (Fig. 8; Appendix D. 3). At the top of the Middle Jurassic series, the sediments of the Toutunhe Fm are interpreted to represent a distal alluvial plain environment (AP2; Appendix D. 4). Following the Toutunhe Fm, a thick red beds series corresponds to the Upper Jurassic Qigu Fm (Appendix D. 5). The basal $315 \mathrm{~m}$ of this formation were interpreted as lacustrine delta deposits (LD) directly followed by $\sim 65 \mathrm{~m}$ of distal alluvial plain sediments (AP2) (Fig. 8). The rest of the Qigu Fm is characterized by a retrogradational trend with environments evolving from distal alluvial plain (AP2), to lacustrine delta (LD) and finally to a playa lake (LE1a). In the latter, desiccation cracks and carbonate nodules are indicative of semi-arid conditions. The transition with the Kalaza Fm is sharp with depositional environments passing from a playa lake (LE1a) to an alluvial fan (AFa) systems (Appendix D. 6, 7). The lower part of the Kalaza Fm corresponds to a rather proximal alluvial fan environment characterized by matrix-supported conglomerates associated with desiccation cracks and sparse root traces indicating arid/semi-arid conditions (AFa) (Fig. 8). It passes up section into horizontal to sub-horizontal laminated clast-supported conglomerates characteristic of a more distal alluvial fan environment and deposited under semi-arid conditions. The transition with the basal part of the Lower Cretaceous Qingshuihe Fm is sharp with environments retrograding sharply toward a lacustrine system (LE1). 
The Wusu section (Fig. 9) is also located on the southern Junggar Basin, to the south

of the Wusu City on the northern flank of the Tian Shan Range (Fig. 1; Appendix E for a general overview of the section). Based on the geological map (XBGMR, 1978a), this 1650 m-thick section encompasses Middle (Xishanyao and Toutunhe fms) to Upper Jurassic (Qigu and Kalaza fms) deposits. The lower and upper parts of this sedimentary section (up to the Qigu Fm) have been respectively logged in the west and east of Saili Keti village (Appendix A for GPS coordinates), with a few meters of overlap expected between them.

The first $190 \mathrm{~m}$ of the Xishanyao Fm correspond to alluvial fan deposits (AF) retrograding sharply towards a $\sim 85$ m-thick unit of lacustrine sediments (LE1) (Appendix E. 1, 2). This unit marks the onset of a 200 m-thick progradational trend with depositional environments evolving from a lacustrine delta (LD) to more and more proximal alluvial plains (AP2, AP1), followed by an alluvial fan system (AF) (Fig. 9; Appendix E. 3). The upper part of the Xishanyao Fm then consists of alluvial fan (AF) and proximal alluvial plain (AP1) deposits. These proximal alluvial deposits are still present in the lower part of the Toutunhe Fm and pass upward into sediments deposited in a more distal alluvial plain environment (AP2) in a retrogradational trend (Fig. 9; Appendix E. 4, 5). Both the Middle Jurassic Xishanyao and the Toutunhe fms contain several tuffaceous beds ( $\mathrm{cm}$ to $\mathrm{dm}$ thick) indicating volcanic activity as well as numerous coal beds associated with alluvial plain deposits indicating rather humid climate conditions. Above, the lower part of the Upper Jurassic Qigu

450 Fm consists of red siltstones and sandstones displaying root traces and interpreted as proximal alluvial plain (AP1) deposits (Appendix E. 6). The upper Qigu Fm displays alluvial fan deposits (AF) retrograding towards proximal alluvial plain (AP1) to distal alluvial plain (AP2a) deposits containing carbonate nodules indicating semi-arid climatic conditions (Fig. 9). The Qigu Fm ends with a sharp boundary marking the transition between the deposits of a 
proximal alluvial plain environment (AP1) and the 150 m-thick Kalaza Fm (Fig. 9). The latter is dominated by planar to sub-planar laminated conglomerates (Appendix E. 7) interpreted as an alluvial fan sediments deposited in semi-arid conditions (AFa). Finally, the transition between the Kalaza Fm and the basal part of the Qingshuihe Fm is marked by a rapid retrogradation towards a distal alluvial plain environment (AP2).

\section{3. 2. Intra-mountain basins}

\section{3. 2. 1. The Nieleke section}

The Nieleke section (Fig. 10) is situated in the Tian Shan Range within the Hexilagen Basin (Fig. 1; Appendix $\mathrm{F}$ for a general overview of the section) and covers $\sim 925 \mathrm{~m}$ of Middle Jurassic (Toutunhe Fm) deposits (XBGMR, 1978b).

The first $310 \mathrm{~m}$ of the section consist mostly of interbedded siltstones and sandstones associated with coal deposits and interpreted to be deposited in a lacustrine delta (LD). Several oxidized paleosols are also visible in the bottom part of this unit (Fig. 10; Appendix F. 1) suggesting warm and humid climatic conditions. The next $410 \mathrm{~m}$ show successive retrogradational and progradational trends with depositional environments evolving from a distal alluvial plain (AP2) to a lacustrine delta (LD) and back to a distal alluvial plain (AP2) deposits (Fig. 10; Appendix F. 2). The upper part of the section is characterized by a $50 \mathrm{~m}$ thick unit of stacked, coarse-grained to gravelly sandstone beds interpreted to be lacustrine delta deposits (LD) (Fig. 10). This marks the onset of a progradational trend from a lacustrine delta (LD) to more and more proximal alluvial plain environments (AP2, AP1) (Appendix F. 3). 


\section{3. 2. 2. The Bayanbulak section}

481

482

The Bayanbulak section (Fig. 11) is situated in the Tian Shan Range, in the northern

483

part of the Bayanbulak Basin (Fig. 1; Appendix G for a general overview of the section). It

484

485

486

487

488

489

490

491

492

493

494

495

496

497

498

499

500

501

502

503

504 presents $\sim 420 \mathrm{~m}$ of Middle Jurassic deposits (XBGMR, 1969), which we attribute to the Toutunhe Fm based on their lithology.

The lowest $\sim 70 \mathrm{~m}$ of sediments of this section indicate a proximal alluvial plain environment (AP1) with several coal deposits. They pass upward into alluvial fan deposits (AF) (Appendix G. 1). The rest of the succession is characterized by an alternation between proximal alluvial plain (AP1) and alluvial fan (AF) deposits (Fig. 11). The last $\sim 20 \mathrm{~m}$ of the section are attributed to the Paleogene (XBGMR, 1969; Heilbronn et al., 2015) and comprise red conglomerates impregnated/cemented by limestone (Appendix G. 2, 3) interpreted to be calcrete formed by long-lasting pedogenic processes within semi-arid, seasonal climates (see table 2).

\section{3. 3. The north Tarim Basin}

\section{3. 3. 1. The Yaha section}

The Yaha section (Fig. 12) is located in the Kuqa depression, of the north Tarim Basin along the Yaha River on the southern flank of the Tian Shan Range (Fig. 1; Appendix H for a general overview of the section). This $\sim 1525$ m-thick section encompasses Lower Jurassic (Yengisar Fm), Middle Jurassic (Kezilenuer and Kalemake fms), Upper Jurassic (Qigu and Kalaza fms), and Lower Cretaceous (Yageliemu Fm) deposits (XBGMR, 1970; Hendrix et al, 1992). 
506

interpreted as lacustrine delta deposits (LD) (Appendix H. 1, 2). They evolve, at the base of the Kezilenuer Fm, towards distal alluvial plain deposits (AP2) and finally back to lacustrine delta sediments (LD) in the upper part of this formation (the last $325 \mathrm{~m}$ ) (Fig. 12; Appendix H. 3, 4). The base of the Kalemake Fm ( 230 m) still consist of lacustrine delta deposits (LD) retrograding toward lacustrine environments characterized by the presence of calcareous beds with some turbiditic events in the top $\sim 200 \mathrm{~m}$ of the formation (Appendix H. 5). Their oxygen and carbon isotope compositions are typical of lacustrine carbonates (Heilbronn et al., 2015). These observations seem to indicate a rather deep lacustrine environment (LE1) in comparison to lake environments encountered in the previous sections. Middle Jurassic units are also associated to numerous coal beds indicating humid climate conditions. The Qigu Fm ( 200 $\mathrm{m}$ in thickness) is characterized by a thick red-bed series (Appendix H. 6) interpreted as playa lake deposits (LE1a) prograding towards more and more proximal alluvial plain deposits associated to carbonate nodules that indicate semi-arid climate conditions (AP2a, AP1a). Above, the Kalaza Fm is particularly thin $(\sim 35 \mathrm{~m})$ in comparison to other sections and consists of alluvial fan deposits (AFa) (Fig. 12; Appendix H. 7). Finally, the lower part of the Lower Cretaceous Yageliemu Fm is characterized by proximal to distal alluvial plain sediments deposited under semi-arid conditions (AP2a, AP1a) (Appendix H. 8). Within the upper part of the section, the sediments evolve towards deposits associated to a more distal lacustrine delta environment (LD).

\section{JURASSIC PALEOGEOGRAPHICAL EVOLUTION OF THE TIAN SHAN}

As mentioned above, the present-day geometry of the range results from a series of Meso-Cenozoic reactivations of late Paleozoic tectonic structures (e.g.,Molnar and Taponnier, 1975; Hendrix et al., 1992; Sobel et al., 1999; Dumitru et al., 2001; De Grave et al., 2007; 
Jolivet et al., 2010). However, the exact pattern of Cenozoic deformation in the Tian Shan

532 Range is still poorly understood. The total Cenozoic shortening is estimated to be $124 \pm 30$

$533 \mathrm{~km}$ at the longitude of Manas (ca. 85,5 $\mathrm{E}$; Chinese Tian Shan) and $203 \pm 50 \mathrm{~km}$ at the

534 longitude of Kashgar (ca. 76 E; Kyrgyz Tian Shan) (Avouac et al., 1993). Though, this

535 deformation is distributed on a number of faults, the exact kinematics of which being poorly

536 constrained with likely significant strike-slip displacements. In addition, no Mesozoic

537 deformation estimates are available. Due to this lack of kinematic constraints, we decided not

538 to attempt to palinspastically restore the proposed paleogeographic maps.

\section{1. EARLY - EARLY MIDDLE JURASSIC}

The Early to early Middle Jurassic paleogeography of the Tian Shan region was characterized by the presence of several sedimentary basins separated by significant reliefs (Fig. 13).

In the northeastern Junggar Basin (Kelameili region), the sedimentation was dominated by alluvial fan and alluvial plain deposits (Eberth et al., 2001; Vincent et al., 2001;

547 Yang et al., 2015), indicating the existence of an eroding relief to the east within the vicinity 548 of the present-day Altai Range. Indeed, Upper Triassic and Lower Jurassic angular

549 unconformities were associated with coarse-grained pulses in the sedimentation suggesting 550 that episodes of deformation and erosion took place in this area (Vincent et al., 2001). This is 551 in agreement with seismic data showing that this region underwent transpressional 552 deformation during Early Jurassic times (Zhao et al, 2014). To the south-east, sedimentation 553 in the Junggar and Turfan basins consisted mainly of alluvial to lacustrine deposits.

554 Widespread perennial lakes and associated lacustrine deltas developed within the central part 555 of both basins while alluvial environments dominated in the areas nearby the reliefs (this 556 study; Hendrix et al., 1992; Eberth et al., 2001; Vincent et al., 2001; Shao et al., 2003; Bian et 
558 sedimentological and provenance analyses seem to indicate the presence of a low relief 559 between the Junggar and Turfan basins (the present day Bogda Shan area) (Hendrix et al., 1992; Greene et al., 2001; Shao et al., 2003; Tang et al., 2014). However, the lack of Early

561 Jurassic ages in the low-temperature thermochronology data of the Bogda Shan area indicates

562 the absence of significant tectonic exhumation (Tang et al., 2015). This suggests that the relief

563 was not derived from an Early Jurassic uplift and deformation event, but was probably inherited from the Permian to Triassic topography.

In the western Junggar Basin (Karamay region), several unconformities within the

Lower Jurassic series are directly followed by conglomerate deposits (Eberth et al, 2010;

567

Deng et al., 2010; Ma et al., 2014) and indicate that several deformation events also occurred in this area. The presence of alluvial fan and alluvial plain environments (Eberth et al., 2001) together with braided delta prograding eastward into a lake (Feng et al., 2015), point again to the existence of an eroding relief in place of the present day Halaalate mountains which provided sediments to the Junggar Basin.

Along the southern margin of the Junggar Basin, depositional environments consisted of alluvial fans to alluvial plains. The occurrence of numerous coal beds together with plant remnants in the associated series suggests rather humid conditions (this study; Hendrix et al., 1992; Eberth et al, 2001). Even though the Early to early Middle Jurassic sedimentation in that area is mostly regarded as continental, Sha et al. (2011) and Pan et al. (2012) suggested the occurrence of brackish water fauna ("Waagenoperna") in the south Junggar Basin indicative of an intermittent connection with the Tethys Sea to the west. However, due to poor preservation, the "Waagenoperna", as figured and described from the Badaowan Fm by Sha et al. (2011, 2016) and Pan et al. (2012) shows none of the characteristic generic features situated on the inner side of the shell (Simon Schneider, pers. com.). Moreover, it co-occurs with other bivalves which are clearly freshwater taxa, as stated by Sha et al. (2011) and Pan et 
583

584

585

586

587

588

589

590

591

592

593

594

595

596

597

598

599

600

601

602

603

604

605

606

607

al. (2012) themselves. We thus propose that the "Waagenoperna" described in the Junggar Basin is most likely a misidentified freshwater bivalve of unknown affinities and that no marine incursion occurred in the southern area of the Junggar Basin during the Early Jurassic epoch.

Along the Manas section (Fig. 1 for location; Fig. 8), the unconformity between the Upper Triassic and Lower Jurassic sediments suggests that deformation and erosion events took place at the southern margin of the Junggar Basin during this period (Eberth et al., 2001; Yang et al., 2015). North directed paleocurrent measurements together with provenance data indicate that these sediments were derived from the south, locating a relief in the place of the present day Tian Shan Range (Hendrix et al., 1992; Yang et al., 2013). These observations are in agreement with low-temperature thermochronology data which highlight a Late Triassic Early Jurassic cooling phase associated with the reactivation of the main Paleozoic structures of the North Tian Shan region (Dumitru et al,, 2001; Jolivet et al., 2010).

Several intra-mountain basins were also active within the Tian Shan Range during the Early to early Middle Jurassic. The Yili Basin was principally occupied by alluvial plain, lacustrine delta and lacustrine environments with coal deposits suggesting humid conditions. The main depocenter was located in the northern part of the basin (Li et al., 2014). To the south, the Zahosu depression was also active ( $\mathrm{Li}$ et al., 2015). Coarse grained fan delta deposits prograding towards the north in the Yili Basin (Li et al, 2014) and the sediment grain-size evolving southward from conglomerates to sandstones and siltstones in the Zahosu depression (Li et al., 2015) imply that a physiographic separation existed between the two basins at that time. To the south-east, preserved Lower Jurassic sediments along the northern edge of the Bayanbulak Basin (XBGMR, 1969) suggest that this depression was also active during this period. Finally a Late Triassic - Early Jurassic cooling phase was identified in the low-temperature thermochronology data along the Narat Range between the Bayanbulak and 
Yili basins. This suggests the presence of an eroding relief separating these basins (Dumitru et al., 2001; Jolivet et al., 2010).

To the south-east of the Tian Shan, the Yanqi Basin presents deposits associated to environments evolving from alluvial fan to lacustrine systems (Al-Qaraafi and Guangqing, 2013). Sedimentological analyses within both the Turfan and Yanqi basins suggest that they were separated from each other by an eroding relief (Shao et al,, 2003; Al-Qaraafi and Guangqing, 2013). However, whether the Yanqi and Tarim basins were connected or separated by a relief during the Early to early Middle Jurassic is unclear due to the lack of data in that region.

During this period, the north Tarim Basin was characterized by alluvial fan systems evolving southward to alluvial plain, lacustrine delta and lacustrine environments (Fig. 12). Provenance analyses together with south directed paleocurrents indicate the existence of an eroding relief to the north forming the main source area for the detrital material deposited in this part of the basin (Hendrix et al., 1992; Li and Peng., 2010; Liu et al., 2013; Wang et al., 2015). The very monogenic (quartz) and well-sorted grain size of the lacustrine delta sediments encountered in the Yaha section (Yengisar Fm; Fig. 12) could indicate that these deposits were possibly reworked from an old weathering profile. This statement is in agreement with the provenance data (Liu et al., 2013) which indicate that topography of the source area could have already been partially flattened at that time.

To the west of the Tian Shan, in the Fergana Basin, renewed subsidence occurred during the Early Jurassic following the erosion event that characterized the Triassic period in that region (Clarke, 1984). This led to the accumulation of 90-400 m-thick deposits in alluvial, lacustrine fan delta to shallow lacustrine environments, which unconformably overlay the Paleozoic basement (Clarke, 1984; De Pelsmaeker et al., 2018). Numerous coal beds and plant remnants were described in these deposits indicating abundant vegetation and humid climate conditions. At the same time, to the east of the Fergana Basin, $\sim 4000 \mathrm{~m}$ of 
sediments were deposited within the Yarkand-Fergana Basin (Sobel et al,, 1999). This strong sediment accommodation is thought to be induced by strike-slip motion on the Talas Fergana/Karatau fault leading to the formation of an Early - Middle Jurassic pull-apart basin (Sobel et al., 1999; Allen et al, 2001; Alexeiev et al., 2017). Within this Yarkand - Fergana Basin, depositional environments consist mainly of alluvial, fan delta and deep lake systems (Sobel et al., 1999; De Pelsmaeker et al., 2018). Low-temperature thermochronology data also indicate a Late Triassic - Early Jurassic cooling phase within the Kyrgyz Tian Shan area probably induced by the reactivation of Paleozoic structures and basement exhumation (Sobel et al., 2006; De Grave et al., 2007, 2012; Glorie and De Grave, 2016; Nachtergaele et al., 2018).

Several Lower to Middle Jurassic outcrops have also been described by De Pelsmaeker et al. (2018) in the Ming-Kush and south Issyk-Kul basins and similar age deposits were observed in both the Naryn and Aksai basins (VNIGNI and Beicip Franlab, 1992) located within the northern part of the present day Kyrgyz Tian Shan (Fig. 1 for location). Generally, the stratigraphic ages of these sediments reported on the geological maps are Lower Jurassic (e.g., Lasovskiy and Mozolev, 1961), however, no biostratigraphic data are available for these series. Sedimentation mainly consisted of alluvial plain, fan delta and shallow lacustrine deposits. These deposits are often associated with coal-rich layers and plant fragments indicating humid climate conditions although some caliche-type paleosols more typical of semi-arid conditions were also identified in the south Issyk-Kul Basin (De Pelsmaeker et al,, 2018; VNIGNI and Beicip Franlab, 1992). Low-temperature thermochronology data support a Middle Triassic - Early Jurassic cooling phase within the basement separating all these basins (e.g., De Grave et al., 2011; Glorie et al., 2011) indicating the presence of eroding reliefs between these intra-mountain basins.

To the north of the Kyrgyz Tian Shan, no Lower Jurassic sediments have been described within the south Chu-Sarysu and Yili-Balkhash basins (VNIGNI and Beicip 
Franlab, 1992; AGMCA, 2008). We propose that these domains were dominated by sediment by-pass (i. e. lowland areas dominated by soil alteration, low erosion and/or low sedimentary export or by a poor preservation of thin sediment deposits) during the Early - early Middle Jurassic. Similarly, no Jurassic sediments have been deposited in the western part of the Tarim Basin, except for Jurassic series exposed more to the south, along the West Kunlun Pamir Range (Lee 1985a, b; Sobel et al., 1999; Yang et al., 2017). We thus propose that this domain was also dominated by sediment by-pass during the Early - early Middle Jurassic. Nevertheless, some restricted piedmonts deposits could have existed that were not preserved within the stratigraphic record.

\section{2. LATE MIDDLE - EARLY LATE JURASSIC}

The late Middle to early Late Jurassic paleogeography of the Tian Shan region was mostly characterized by sedimentary basins surrounded by relatively low- relief basement areas (Fig. 14).

In the northeastern Junggar Basin (Kelameili region), the late Middle - early Late Jurassic strata consist mainly of alluvial plain to shallow lacustrine deposits (Eberth et al., 2001; Vincent et al., 2001). These environments are more distal compared to the Early Jurassic ones and potentially indicate a lowering or a retreat further to the east of the Early Jurassic relief. However, some local Middle Jurassic unconformities have been identified in this area which suggests recurrent periods of localized deformation and erosion (Eberth et al., 2001; Vincent et al, 2001). To the north-east, in the Junggar and Turfan basins, late Middle early Late Jurassic deposits reflect alluvial to lacustrine depositional environments (this study; Hendrix et al., 1992; Eberth et al., 2001; Vincent et al., 2001; Shao et al, 2003; Bian et al, 2010; Yang et al., 2015). The paleocurrent measurements, sedimentological analyses and provenance studies indicate the presence of an existing relief between the two basins 
persisting from the Early Jurassic (Hendrix et al., 1992; Shao et al., 1999, 2003; Tang et al., 2014; Ji et al., 2017). Based on provenance studies, some authors proposed that this area also underwent several uplift episodes during the Middle Jurassic (Tang et al., 2014; Ji et al, 2017). However, the lack of contemporaneous exhumation ages and the occurrence of fine grained sediments in both the Junggar and Turfan basins rather suggest the absence of strong exhumation events in this region (Shao et al, 2003; Tang et al., 2015; Yang et al., 2015).

To the west of the Junggar Basin (Karamay region), the sedimentation was dominated by alluvial fan to alluvial plain deposits (Eberth et al, 2001). The presence of a Middle Jurassic unconformity sealed by conglomerates again indicates that deformation persisted in that area during this period (Eberth et al., 2001; Deng et al., 2010).

Along the southern margin of the Junggar Basin, the strata exposed in the Wusu section consist mainly of alluvial fan to alluvial plain deposits (Fig. 9). Further east, along the Manas and Toutunhe sections, the sediments are characteristic of more distal environments such as alluvial plain to lacustrine delta (Figs. 6, 7, 8) (this study; Hendrix et al, 1992; Eberth et al., 2001; Deng et al., 2010). North-oriented paleocurrents attest of the presence of an eroding relief to the south (Hendrix et al., 1992). The more distal depositional environments in the Manas region potentially indicate that this relief was lower or located further south than during the Early Jurassic. This trend is in agreement with the low-temperature thermochronology data which associate the Middle Jurassic to a period of low basement cooling rates and thus to a period of flattening of the relief in the North Tian Shan region (Dumitru et al., 2001; Jolivet et al., 2010). In the southern margin of the Junggar Basin, the late Middle Jurassic deposits contain numerous coal beds (Figs. 6, 7, 8) (this study; Hendrix et al., 1992; Eberth et al., 2001; Deng et al., 2010). The occurrence of these coal beds indicates that rather humid conditions persisted during that period. This coal disappears in the early Late Jurassic deposits, while extensive calcareous paleosols indicative of semi-arid conditions developed (This study; Hendrix et al., 1992; Eberth et al., 2001; Vincent et al., 2001; Deng et 

al., 2010 Jolivet et al, 2017a). Several volcanic tuff layers and syn-sedimentary volcanic

713 zircons have also been described in the Middle Jurassic series along the southern margin of 714 the Junggar Basin (Wusu and Manas sections, Bogda Shan) indicating a volcanic activity

715 within the north Tian Shan region during that period (Fig. 9; Yang et al., 2013; Simonov et al., 2015; Ji et al., 2017). However, the eruption center has not yet been located.

The Middle Jurassic sediment in the Yili Basin consists of alluvial to lacustrine deposits (Fig. 10; Li et al, 2014). Due to the absence of coarse grained sediments and to the presence of extensive coal beds in the southern part of the basin as well as in the Zahosu depression immediately to the south ( $\mathrm{Li}$ et al 2014; Li et al., 2015), we suggest that no erosive domain separated these two basins during that period. However, the occurrence of alluvial fan to proximal alluvial plain deposits in the northern part of the Bayanbulak Basin (Fig. 11) implies the existence of a nearby eroding relief. Moreover, low-temperature thermochronology data indicate a Middle Jurassic period of slow cooling in the Narat region interpreted as a period of slow erosion (Dumitru et al., 2001; Jolivet et al., 2010). We thus propose that the relief established along the Narat fault during the Late Paleozoic - Early Jurassic was not entirely flattened by Middle Jurassic and therefore, that it still constituted a physiographic separation between the Bayanbulak and Yili basins.

To the south-east of the Tian Shan, no data are available for the Middle - Late Jurassic strata of the Yanqi Basin. However, sedimentological analyses within the Turfan Basin indicate the presence of an eroding relief separating the Turfan Basin from the Tarim Basin (Shao et al., 2003).

Along the Yaha section in the north Tarim Basin, the Middle Jurassic strata were deposited in alluvial plain to lacustrine environments (Fig. 12). South-directed paleocurrents and provenance analyses also indicate the presence of an eroding relief to the north (Hendrix et al., 1992; Li and Peng., 2010; Liu et al., 2013; Wang et al., 2015). However, the more distal depositional environments compared to the Early Jurassic ones suggest a lowering or a 

stratigraphic record. (Liu et al., 2013).

northward retreat of the relief with a widening of the basin. This is also supported by detrital zircon $\mathrm{U}-\mathrm{Pb}$ data showing a widening of the sediment source area during the Middle Jurassic

To the west of the Tian Shan, the Middle Jurassic series in the Fergana Basin consist of 100-300 m-thick alluvial to lacustrine deposits (Clarke, 1984; De Pelsmaeker et al., 2018). Coal beds and plant fragments are abundant within these sediments and indicate humid conditions (De Pelsmaeker et al., 2018). To the east of the Fergana Basin, the YarkandFergana Basin was still subsiding due to strike-slip motion along the Talas Fergana/Karatau fault and it accommodated $\sim 600-1550 \mathrm{~m}$ of Middle Jurassic sediments (Sobel et al., 1999; Allen et al., 2001; Alexeiev et al, 2017). The facies of the latter indicate the occurrence of alluvial plain, lacustrine delta and lacustrine depositional environments (Sobel et al, 1999; De Pelsmaeker et al, 2018). Like in the Chinese Tian Shan, low-temperature thermochronology data indicate low cooling rates during the Middle Jurassic within the Kyrgyz Tian Shan. This was interpreted as a period of slow erosion leading to progressive planation of the basement areas (De Grave et al., 2007, 2013; Macaulay et al., 2014; Glorie and De Grave, 2016). Meanwhile, in the Ming-Kush, south Issyk-Kul, Naryn and Aksai basins, a Middle Jurassic to Eocene hiatus in sedimentation has been identified (VNIGNI and Beicip Franlab, 1992; Burbank et al., 1999; De Pelsmaeker et al., 2018).

Further north, no Middle - Late Jurassic sediments were described within the south Chu-Sarysu and Yili-Balkhash basins (VNIGNI and Beicip Franlab, 1992; AGMCA, 2008). We propose that these domains were still dominated by sediment by-pass during this period. Similarly to the Early Jurassic period, the western Tarim Basin seems also dominated by sediment by-pass during the Middle - Late Jurassic (Lee 1985a, b). Nevertheless, some restricted piedmonts deposits could again have existed that were not preserved within the 


\section{3. LATE JURASSIC - EARLY CRETACEOUS TRANSITION}

In the Tian Shan region, the Late Jurassic - Early Cretaceous transition corresponds to a drastic paleogeographic change in comparison to the Early and Middle Jurassic periods (Fig. 15). In the Junggar and Turfan basins, the sedimentation was dominated by alluvial fan to alluvial plain deposits (Hendrix et al., 1992; Shao et al., 1999; Eberth et al., 2001; Vincent et al., 2001; Bian et al., 2010; Jolivet et al., 2017a). Low-temperature thermochronology data indicate a Jurassic - Early Cretaceous fast cooling event in the present day Bogda Shan area implying that this region underwent deformation and uplift during this period (Tang et al., 2015).

To the north-east and north-west of the Junggar Basin, in the Kelameili and Karamay regions (Fig. 15), the Upper Jurassic - Lower Cretaceous deposits are associated with alluvial fans and alluvial plain environments (Eberth et al., 2001; Vincent et al., 2001; Jolivet et al., 2017a). Angular unconformities at the base of the alluvial fans sediments (corresponding to the Kalaza Fm) have been identified in both regions and are, in the Kelameili area, associated with incised paleo-valleys (Eberth et al., 2001). They imply uplift and relief building in these areas, in agreement with the seismic data indicating that transpressive deformation occurred within the eastern and western part of the Junggar Basin during the Jurassic (Zhao et al, 2014; Yu et al., 2016). Such a tectonic setting could have led to widespread deformation leading to the generation of a relief within the Junggar Basin.

Indeed, a NE-SW-orientated erosional area, the Chemo uplift, started to develop within the central part of the Junggar Basin during the Middle Jurassic and reached its peak stage during the Late Jurassic - Early Cretaceous (Lianhua et al, 2009; Yang et al., 2015; Gao et al., 2017). Erosion of this topographic high provided terrigenous material that was shed into the adjacent, still subsiding areas (Lianhua et al., 2009; Yang et al., 2015; Gao et al., 2017). 
Based on seismic data, Lianhua et al. (2009) estimated that the amplitude of this paleorelief

790

791

792

793

794

795

796

797

798

799

800

801

802

803

804

805

806

807

808

809

810

811

812

813 could have reached $740 \mathrm{~m}$ during its peak development stage.

Along the southern margin of the Junggar Basin, the sedimentation consisted mainly of several meters to hundred meters-thick alluvial fan deposits typical of semi-arid to arid climate conditions (Figs. 6, 8, 9) (this study; Jolivet et al., 2017a). Indeed, aeolian deposits are present in the Kelameili and Toutunhe regions (Fig. 1 for location). Along the south Toutunhe section, they are interbedded with ephemeral alluvial fan deposits (Fig. 6) and evolved northward to erg deposits with large dunes and interdunes (Fig. 7). The occurrence of these thick aeolian deposits indicate that this region was under semi-arid to arid climate conditions during the Late Jurassic - Early Cretaceous (this study; Eberth et al., 2001; Vincent et al., 2001; Jolivet et al., 2017a).

As in the north of the Junggar Basin, angular unconformities have been identified at the base or within the Kalaza Fm (Hutubi and North Toutunhe sections) (this study; Jolivet et al., 2017a). Moreover, provenance analyses demonstrate that recycling of Mesozoic sediments took place in this area. These observations imply that some tectonic movements and rock uplift also occurred during the Late Jurassic - Early Cretaceous within the North Tian Shan foothills (Yang et al., 2013). However, low-temperature thermochronology data on basement rocks from the central Tian Shan do not identify any evidence of tectonic movements during this period and show that exhumation was in fact controlled by slow erosion since the Middle Jurassic (Dumitru et al., 2001; Jolivet et al., 2010). Accordingly, we propose that small amplitude tectonic movements occurred within the North Tian Shan Range and its piedmont, leading to limited relief building during the Late Jurassic - Early Cretaceous.

Within the Tian Shan Range, both Yili and Bayanbulak basins do not contain Upper Jurassic - Lower Cretaceous sediments (AGMCA, 2008). Following an Late Jurassic - Early Cretaceous unconformity, a $\sim 40$ m-thick weathered layer formed within the Yili Basin, overlain by Upper Cretaceous sediments and indicating rather stable conditions for a long 
815

816

817

818

819

period of time (VNIGNI and Beicip Franlab, 1992). Therefore, we propose that this domain was dominated by sediment by-pass during the Late Jurassic - Early Cretaceous. To the south, low-temperature thermochronology data indicate slow cooling, hence low erosion within the Narat Range. This suggests a continuous flattening of the topography during this period (Dumitru et al., 2001; Jolivet et al., 2010). In the Bayanbulak Basin, Eocene (?) strata rest unconformably on the Middle Jurassic series again implying that the basin was dominated by sediment by-pass and/or erosion during the Late Jurassic - Early Cretaceous.

To the south-east of the Tian Shan, the relation between the Yanqi and the Tarim basins is not clear. No Upper Jurassic - Lower Cretaceous sediments were described within the Yanqi Basin (AGMCA, 2008; Huang et al., 2015). We therefore propose that this region was dominated by sediment by-pass during this period.

In the northern part of the Tarim Basin, the Late Jurassic - Early Cretaceous sedimentation was characterized by relatively thin alluvial fan deposits (in comparison to the Junggar Basin) evolving southward towards alluvial plain deposits (Fig. 15). Provenance and petrographic analyses point to a sediment source from the South Tian Shan Range, altogether with local recycling of Mesozoic sediments indicating a southward migration of the eroding topography (Li et al., 2004; Li and Peng, 2010).

To the west, the Late Jurassic - Early Cretaceous sedimentation in the Fergana Basin consisted of alluvial fan and alluvial plain deposits (Fig. 15). In the northern part of the basin (Tash-Komyr section; Fig. 1), the transition between the Jurassic and the Cretaceous is marked by an erosional unconformity directly followed by $>110 \mathrm{~m}$-thick alluvial fan deposits (De Pelsmaeker et al,, 2018). This suggests that some tectonic movements occurred during that period. To the south (Jetim-Dobo section; Fig. 1) the sedimentation consists of alluvial plain deposits containing calcareous paleosols, and indicating semi-arid climate conditions (De Pelsmaeker et al., 2018). 
Meanwhile to the east, alluvial fan and proximal alluvial plain systems developed in the western and southern parts of the Yarkand-Fergana Basin (Sobel et al., 1999; De Pelsmaeker et al, 2018). Provenance studies on Late Jurassic - Early Cretaceous samples indicate potential recycling of older Jurassic sediments and smaller drainage area compared to the Early - Middle Jurassic paleogeography (De Pelsmaeker et al., 2018). Together, these data imply a Late Jurassic - Early Cretaceous inversion of the Yarkand-Fergana Basin. This renewed tectonic activity is further supported by low-temperature thermochronology data which identify a Late Jurassic -Early Cretaceous cooling event in the Kyrgyz Tian Shan Range suggesting a localized relief building (De Grave et al., 2007, 2012, 2013; Glorie and De Grave., 2016; Nachtergaele et al., 2018).

No Upper Jurassic - Lower Cretaceous sediments were described within the ChuSarysu, Yili-Balkash and west Tarim basins (Lee 1985a, b; VNIGNI and Beicip Franlab, 1992; AGMCA, 2008). We therefore propose that these domains were still dominated by sediment by pass during this period even though some restricted piedmont deposits could have existed and not subsequently preserved within the stratigraphic record.

\section{DISCUSSION}

\section{1. TOPOGRAPHIC AND CLIMATIC EVOLUTION OF THE TIAN SHAN}

The Jurassic topographic evolution of the Tian Shan was dominated by the progressive planation of a late Paleozoic to early Mesozoic relief, locally interrupted by discreet topographic rejuvenations (Fig. 16) (e.g., this study, Dumitru et al., 2001; Jolivet et al., 2010; Li and Peng, 2010; Liu et al., 2013; Macaulay et al, 2014). In both the north and south Tian Shan foothills, a progressive transition can be observed from Early Jurassic coarse-grained sediments associated with proximal alluvial environments, to finer-grained deposits 
characteristic of distal alluvial to lacustrine systems during the Middle Jurassic (this study;

867 Hendrix et al., 1992; Eberth et al., 2001; Bian et al., 2010). This highlights the progressive

868 decrease of the Tian Shan relief. During the Early to Middle Jurassic, the sedimentation, in the basins surrounding the range and in the intra-mountain depressions, was characterized by alluvial to lacustrine deposits containing numerous coal beds and plant fragments indicating 871 humid climate conditions (Fig. 16; this study; Hendrix et al, 1992; Sobel et al., 1999; Eberth 872 et al., 2001; Bian et al., 2010; De Pelsmaeker et al., 2018). Finally, the Middle Jurassic period 873 was also characterized by volcanic activity within the north Tian Shan region (this study; 874 Yang et al., 2013; Simonov et al., 2015; Ji et al., 2017). During the early Late Jurassic, the 875 Tian Shan relief was still decreasing, with contemporaneous fine-grained sediments deposited 876 in distal alluvial to lacustrine environments. However, this period was marked by a change in 877 climate conditions, recorded all over the Tian Shan area by the disappearance of the humid 878 conditions marked by coal layers and the extensive formation of calcareous paleosols, 879 indicative of semi-arid conditions (this study; Hendrix et al., 1992; Eberth et al., 2001; 880 Vincent et al., 2001; De Pelsmaeker et al., 2018). This Late Jurassic aridification affected 881 most of Central Asia and was also identified in the West Siberian Basin (e.g., Hendrix et al., 882 1992; Le Heron et al., 2008) and within the Turan domain where sedimentation partly consisted on thick evaporite units (Brunet et al., 2017). leading to localized relief building within the Tian Shan and coarse-grained proximal alluvial deposits surrounding the range (Fig. 16) (; De Grave et al., 2007, 2012, 2013; Tang et al.,

887 2015; Glorie and De Grave., 2016; Nachtergaele et al., 2018). Meanwhile, the Yili and 888 Bayanbulak basins were dominated by sediment by-pass and/or limited erosion. 889 Contemporaneous, limited relief building is also suggested in the Altai (Eberth et al,, 2001; 890 Yuan et al., 2006). The Late Jurassic - Early Cretaceous transition was further characterized 891 by the climax of the aridification trend which was prevailing since the early Late Jurassic. In 

the Junggar Basin, this peak in aridity has been associated to the deposition of alluvial fans together with large - scale aeolian dunes (Jolivet et al., 2017a).

\section{2. AN EARLY - MIDDLE JURASSIC KINEMATIC FRAMEWORK DRIVEN BY}

\section{FAR-FIELD TECTONICS}

The Jurassic tectonic and topographic evolution of the Tian Shan region is thought to be mostly controlled by compressive or transpressive events at continental scale (Allen et al., 1991; Hendrix et al., 1992; Sobel et al., 1999; Vincent et al., 2001; Allen et al., 2001; Yang et al., 2015). Thus, Late Triassic-Early Jurassic evidences of deformation in the area are often related to the Qiangtang collision along the southern margin of Eurasia to the south, which ended at that time (Kapp et al., 2007; Roger et al., 2010). However, no major collision episode has been reported along this Eurasian margin between the Qiangtang collision and the Early Cretaceous Lhasa collision (Kapp et al., 2007; Roger et al., 2010). The absence of significant collision suggests that other kinematic events occurred during the Jurassic, leading to tectonic activity in the Tian Shan region. To the south, in the Tibet area, no major Jurassic geodynamic event has been described (Roger et al., 2004, 2010; Reid et al., 2005). To the north-east, the timing of the final closure of the Mongol-Okhotsk Ocean remains poorly constrained. It is thought to occur during the Late Jurassic-Early Cretaceous time (e.g.,Zorin, 1999; Donskaya et al. 2013; Daoudene et al., 2017) and was probably not associated with strong compressive deformation (Fig. 17. A) but rather with distributed extension affecting a thin, abnormally warm crust (Daoudene et al., 2017; Jolivet et al., 2017b).

As mentioned above, in the Tian Shan region, east of the Talas Fergana/Karatau fault, the first order geometry of the Jurassic sediments preserved within the Tarim and Junggar basins is characterized by depocenters located along the Tian Shan Range (Fig. 17. B) (Lee, 1985; Hendrix et al., 1992; Bian et al., 2010; Yang et al, 2015). Moreover, recurrent periods 
of localized and limited Jurassic deformation associated with thrust faults have been reported within the two basins (e.g.,Eberth et al., 2001; Vincent et al., 2001; Liu et al., 2006; Wang et al., 2012; Zhao et al., 2014; Chen et al, 2015; Ma et al., 2015; Yang et al., 2015). These

921

922 observations indicate that the Jurassic Junggar and Tarim basins were compressive basins and that the Tian Shan region was under compressional setting at that time (Allen et al., 1991; Hendrix et al., 1992; Yang et al, 2015). Nonetheless, the Early-Middle Jurassic period was mainly characterized by the progressive planation of the Tian Shan relief established during the late Paleozoic - early Mesozoic (Dumitru et al., 2001; Jolivet et al., 2010; Glorie and De Grave, 2016). This implies that no major compressive tectonic event leading to an extensive relief building occurred in that area. The attested recurrent tectonic activity, together with the absence of a major relief build-up during this period, suggest strike-slip fault kinematics with limited vertical motion rather than true compressional tectonics. This idea is supported by seismic data interpretations that also indicate a Jurassic transpressional deformation in the Junggar Basin (Liu et al., 2006; Wang et al., 2012; Yu et al., 2016), which is potentially related to the Jurassic- Early Cretaceous rotation of the Junggar block (Lianhua et al., 2009; Yu et al., 2016). Jurassic to Cretaceous strike-slip tectonics has also been described in the eastern part of the Tarim Basin (Wang et al., 2012) as well as extensional faults (Yang et al., 2017).

In the Tian Shan area, several NW-SE and E-W oriented lithospheric faults (e.g.,the Talas Fergana fault, the Nikolaev line, the North Tian Shan fault and numerous smaller ones) accommodated late Paleozoic block rotations (Bazhenov et al., 1999; Van Der Voo et al., 2006 and references therein). Similarly, we propose that these structures could have been reactivated during the Jurassic accommodating the rotation of several blocks localized in the Tian Shan region. Such motion would favor the development of localized, small scale relief along these main faults. Early Jurassic reactivation along the Talas Fergana/Karatau fault has indeed been identified by kinematic analysis conducted on the south Turgay Basin and by 
geochronological studies (Rolland et al., 2013; Alexeiev et al., 2017).Along the southern edge

945 of the Tarim Basin, geochronology data indicate that strike-slip motion of the Altyn Tagh fault occurred during Middle Jurassic times (Sobel et al., 2001; Liu et al., 2007). However, the

947 exact kinematic of these strike-slip motion as well as the direction of rotation of the blocks localized in the Tian Shan region is still unclear. Indeed, Jurassic clockwise or anticlockwise rotation of the Junggar Basin has been proposed in the literature (for example respectively in Lianhua et al., 2009 and Yu et al., 2016). Similarly, both Jurassic dextral and sinistral motion along the Altyn Tagh fault have been suggested (Sobel et al., 1999; Liu et al, 2007). Finally, post early Permian sinistral strike-slip motion has been identified along the Nikolaev line in Kyrgyztan (Bazhenov and Mikolaichuk, 2004) but it is not clear if this kinematic prevailed during the Jurassic.

West of the Talas Fergana/Karatau fault,compressional events of regional significance occurred throughout the Caspian, Turan and south Kazakh domains during the Late Triassic leading to the inversion of numerous basins in this area (Otto, 1997; Thomas et al., 1999). Following this compressional phase, a widespread late Early to Middle Jurassic extension associated to back-arc development driven by the northward subduction of the Neo-Tethys oceans affected these regions (Zonenshain and Le Pichon 1986; Nikishin et al. 1998; Thomas et al., 1999; Brunet et al, 2003, 2017; Robert et al., 2014; Mordvintsev et al., 2017). This extension reactivated mainly NW-SE orientated Paleozoic structures as normal faults. In turn, these normal faults induced localized subsidence leading to the emplacement of elongated NW-SE depocenters in the Amu-Darya and Kopet Dagh basins (Fig. 17) (e.g., Robert et al., 2014; Brunet et al., 2017; Mordvintsev et al., 2017). Further east, Triassic - Middle Jurassic extension has also been reported in the western part of the Afghan - Tajik Basin (Brookfield and Hashmat, 2001).

Accordingly, the Talas Fergana/Karatau fault seems to be a major NW-SE structure separating the Tian Shan domain to the east, dominated by possible strike slip tectonics and 
block rotations and the Turan and southwest Kazakh domains to the west, dominated by extension. Along this fault, several basins formed during the Early-Middle Jurassic (Fig. 17). To the north, the South Turgay Basin is characterized by a series of $\mathrm{N}$ to $\mathrm{NW}$ orientated grabens and half grabens, separated by basement highs and filled by up to $2.5 \mathrm{~km}$ of Lower to Middle Jurassic fluvio-lacustrine sediments (Moseley and Tsimmer, 2000; Allen et al, 2001; Shi et al., 2016; Alexeiev et al., 2017). Within the central part of the Talas Fergana/Karatau fault, the Leontiev Graben is an elongate basin containing up to $1.5 \mathrm{~km}$ of Jurassic fluvial and lacustrine sediments (Sobel et al,, 1999; Allen et al., 2001). Finally, at the south-eastern termination of the fault, the Yarkand-Fergana Basin consists of thick (c. a. $5 \mathrm{~km}$ ) Lower to Middle Jurassic series of continental deposits (Sobel et al., 1999; De Pelsmaeker et al., 2018). Several studies propose that these basins formed in response to dextral strike-slip motion along the Talas Fergana/Karatau fault. This would induce the opening of the South Turgay Basin as a trailing imbricate fan and the opening of both the Leontiev and Yarkand-Fergana basins, either as dextral transtensional structures at right-stepping jogs in the fault system (e.g., Allen et al., 2001; Alexeiev et al., 2017) or as pull-apart basins (Sobel et al., 1999). This kinematic model has been mainly based on geometrical analysis of seismic data conducted on the Turgay system (Alexeiev et al,, 2017). These authors suggest that consequent Jurassic dextral strike-slip motion occurred along the Talas Fergana/Karatau fault, and its maximum offset was estimated by Alexeiev et al., (2017) to reach $70 \mathrm{~km}$. On the other hand, Burtman (1980) considered Jurassic slip as insignificant along this fault in the Kyrgyztan region. Finally, the driving mechanism leading to such dextral motion along the Talas Fergana/Karatau fault during the Early to Middle Jurassic period is yet to be fully understood. Indeed, the precise onset age of formation of these basins is unclear. In the Leontiev Basin, Lower Jurassic sediments have a pre Toarcian age based on palynological and geochemical studies (Schnyder et al,2016) while no clear stratigraphic ages are available for the south Turgay and Yarkand Fergana basins. Geochronological data indicate that the Talas 
Fergana/Karatau fault was already active close to the Triassic - Jurassic transition in the

997 Kyrgyz region (Rolland et al, 2013). The only coeval geodynamic event known in this region 998 that could cause such dynamic is the Qiangtang collision which ended during the Late 999 Triassic-Early Jurassic (Kapp et al., 2007). Therefore we propose that the early Early Jurassic 1000 dextral motion along this fault could have been induced by far-field effects of the final stage 1001 of the Qiangtang collision. However, it is difficult to understand how such a far-field induced compressional regime could have led to the opening of the Yarkand-Fergana Basin. Indeed,

1004

1005

1006

1007

1008

1009

1010

1011

1012

1013

1014

1015

1016

1017

1018

1019

1020

1021 Sobel et al. (1999) proposed the existence of a strike-slip fault system located in the Kunlun area during that same period, allowing the formation of a Jurassic transtensional basin encompassing both the Yarkand-Fergana and the western Tarim Jurassic deposits. However, seismic data obtained within the western margin of the Tarim Basin neither show the presence of a Jurassic depot-center nor the presence of any fault parallel to the Talas Fergana/Karatau one in this area (Fig. 17) (Yang et al., 2017). This implies that both of these systems were disconnected from each other at that time. Moreover, opening of these basins continued during the late Early to Middle Jurassic (Sobel et al., 1999; Moseley et al., 2000; Allen et al., 2001; Alexeiev et al., 2017). During this period, no major collisional event has been identified along the Eurasian margin implying that another kinematic event induced the tectonic activity observed along the Talas Fergana/Karatau fault. As mentioned previously, simultaneous widespread extension affected the whole Caspian-Turan domains to the west. We propose that this subduction related extension could also have affected the Talas Fergana/Karatau region leading to continuous opening of the South Turgay, Leontiev and Yarkand Fergana basins during the late Early-Middle Jurassic period.

Therefore, we propose that the early Early Jurassic evolution of the Tian Shan region was driven by the far-field effects of the Qiangtang collision final stage. However, recurrent tectonic activity persisted throughout the Tian Shan region during the Early - Middle Jurassic and such dynamic cannot be explained by this collision. The only regional geodynamic event 

affecting Central Asia during this period is the subduction of the Neotethys oceans which led to extension throughout the Caspian, Turan and south Kazakh domains (Zonenshain and Le Pichon 1986; Nikishin et al. 1998; Thomas et al., 1999; Brunet et al., 2003, 2017; Robert et al., 2014; Mordvintsev et al., 2017). We therefore assume that the extensional stress-field induced by the Neo-Tethys subduction also played a major role in driving the late Early to early Middle Jurassic tectonic and topographic evolution of the Tian Shan region. The farfield extension could have led to continuous opening of the basins previously formed along the Talas-Fergana Karatau fault while the rest of the Tian Shan was still possibly dominated by strike slip tectonics accommodated by the reactivation of the major NW-SE and E-W Paleozoic structures located within the range.

\section{3. A LATE MIDDLE TO EARLY LATE JURASSIC PERIOD OF RELATIVE} TECTONIC QUIESCENCE

As explained above, the Jurassic topographic evolution of the Tian Shan Range was dominated by the progressive planation of a late Paleozoic to early Mesozoic relief. By Late Jurassic, almost all of the Tian Shan relief was thus flattened. Accordingly, even if a tectonic activity still occurred during the late Middle - early Late Jurassic, leading to the building of the Chemo uplift in the western part of the Junggar Basin for example (Lianhua et al., 2009; Yang et al., 2015; Gao et al., 2017), it stayed moderate and localized on the major tectonic structures. Meanwhile, west of the Talas Fergana/Karatau fault, this period marked the onset of a post rift phase dominated by thermal subsidence following extension in the Caspian Turan - Kazakh domains (Thomas et al., 1999; Brunet et al., 2017; Mordvintev et al., 2017). Thermal subsidence also occurred in the South Turgay and Fergana basins (Clarke, 1984; Moseley and Tsimmer, 2000; Alexeiev et al., 2017). 

FAR-FIELD COLLISION AND CLIMATE

The Late Jurassic - Early Cretaceous transition corresponds to a period of renewed transpression and localized uplift in the Tian Shan area (this study; Hendrix et al., 1992; Eberth et al., 2001; Vincent et al., 2001; De Grave et al., 2007, 2012, 2013; Yang et al., 2015; Tang et al., 2015; Glorie and De Grave., 2016; Nachtergaele et al,, 2018). Throughout the region, this period is marked by a sharp change in depositional environments with the emplacement of alluvial fan systems in the adjacent Junggar, Turfan, Tarim and Fergana basins. Along the Junggar Basin margins, the presence of angular unconformities at the base of conglomerate deposits indicates that tectonic movements occurred during this period (Hendrix et al., 1992; Eberth et al, 2001; Vincent et al., 2001). Meanwhile, the Chemo-uplift reached its peak stage leading to the formation of a widespread paleorelief within the basin (Lianhua et al., 2009; Yang et al., 2015; Gao et al., 2017). Similarly, in the Fergana Basin, the presence of an angular unconformity sealed by alluvial fan systems at the Jurassic-Cretaceous transition suggests that some tectonic movements occurred (De Pelsmaeker et al., 2018). Finally, Late Jurassic-Early Cretaceous compression has also been identified along the Talas Fergana/Karatau fault, since tectonic inversion and deformation have been described in the South Turgay (Yin et al., 2012), Leontiev (Allen et al., 2001) and Yarkand-Fergana basins (De Pelsmaeker et al., 2018). However, if episodes of deformations have been reported in the Tian Shan region, numerous large-scale, pre-orogenic planation surfaces have been preserved throughout the Tian Shan Range (e.g., Burbank et al., 1999; De Grave et al., 2011; Jolivet et al., 2010; Jolivet, 2017). In the western Tian Shan, Upper Cretaceous strata overlying perfectly flat surfaces imply that no high relief existed in this region during the Early

1072 Cretaceous. Meanwhile, low temperature thermochronology data identified localized Late 1073 Jurassic -Early Cretaceous cooling event in the Kyrgyz Tian Shan Range suggesting only 
restricted relief building (De Grave et al., 2007, 2012, 2013; Glorie et al., 2011; Glorie and De

1075 Grave., 2016; Nachtergaele et al., 2018). However, despite, the lack of strong relief build up,

this period is characterized by the emplacement of extensive alluvial fan systems in the basins surrounding the range (Fig. 15). Their development could be also strongly controlled by the contemporaneous climate aridification affecting this region (Jolivet at al., 2017a).

To the west of the Tian Shan area, a Late Jurassic - Early Cretaceous phase of tectonic deformation associated to the accretion of the Helmand Block also affected the Caspian Turan -Kazakh domains and led to the inversion of the southern basins of Central Iran and Central Afghanistan (Brunet et al., 2017). This deformation event also induced uplift within the Amu-Darya Basin (Brunet et al., 2017) and up to the North Ustyurt Basin (Otto, 1997).

Based on the concordant ages of these events, we suggest that the Late Jurassic - Early Cretaceous tectonic activity and the renewed localized relief building observed in the Tian Shan area was mainly related to the accretion of the Helmand Block to the south-west, and possibly to the onset of accretion of the Lhasa Block along the southwestern margin of Eurasia. This could also explain why stronger relief building occurred in the western part of the Tian Shan compared to its eastern part.

\section{CONCLUSIONS:}

Using both detailed field analysis conducted on the Chinese Tian Shan region and previously published data we reconstructed the Jurassic paleogeographical evolution of the Tian Shan region.

Following a Late Triassic - Early Jurassic period of relief build-up, the Early to early Middle Jurassic topographic evolution of the Tian Shan Range was dominated by the progressive planation of this previously established relief, locally interrupted by discreet topographic rejuvenations. Throughout the region, the contemporaneous sedimentation was 
characterized by alluvial to lacustrine deposits settled under rather humid conditions.

Sediment by-pass dominated to the north-west and south-west of the range, in the ChuSarysu, Yili-Balkhash and west Tarim basins. The Early to early Middle Jurassic was also marked by recurrent limited deformation events recorded within the basins surrounding the range and associated with both strike-slip and compressive tectonics. These episodes of 1105 deformation cannot be explained by the Qiangtang collision but could instead, be associated 1106 to the coeval subduction-related extension affecting the Caspian - Turan domains to the west of the Tian Shan area. During the late Middle to early Late Jurassic, the planation of the Paleozoic - early Mesozoic Tian Shan Range continued with contemporaneous fine-grained sediments being deposited in distal alluvial to lacustrine environments throughout the area, except to the north-west and south-west where sediment by-pass still prevailed. During that period, a drastic climate change occurred across the entire Tian Shan region, shifting from humid conditions during the late Middle Jurassic to more semi-arid conditions during the Late Jurassic. At that time, relatively few evidences of deformation exist in the Tian Shan. Further west, the tectonic evolution is marked by the onset of a post-rift phase dominated by thermal subsidence following the extension in the Caspian - Turan domains, and up to the South Turgay and Fergana basins.

By Late Jurassic, almost all of the Tian Shan relief was flattened. The Late Jurassic -

Early Cretaceous transition was then marked by a tectonic reactivation leading to localized relief building in the Tian Shan and to the deposit of coarse-grained proximal alluvial sediments. Contemporaneously, the sediment by-pass and erosion extended within and around 1121 the range. In addition, the Late Jurassic - Early Cretaceous transition was characterized by the climax of the aridification trend prevailing since the early Late Jurassic. This aridification trend also played a major role in the Late Jurassic - Early Cretaceous paleogeography of the Tian Shan. At that time, renewed deformation and uplift occurred in the Tian Shan area from west to east, leading to the inversion of the Yarkand-Fergana Basin and to the formation of 

localized relief builds up. We propose that this renewed transpressive deformation phase was mainly related to the coeval accretion of the Helmand Block to the south-west, and possibly to the onset of the accretion of the Lhasa Block along the southwestern margin of Eurasia.

\section{AKNOWLEDGMENTS}

This work was supported by the Darius program. The work of Laurie Barrier for this publication is the IPGP contribution \#3933. We want to thank S. Schneider for his expertise on the bivalves of the Badoawan Fm, S. Vincent for constructive discussions and anonymous reviewers for these constructive comments which improved the original version of the manuscript.

\section{REFERENCES}

Alexeiev D.V., Biske Yu.S., Wang Bo, Djenchuraeva A.V., Getman O.F., Aristov V.A., Kröner A., Liu H.S., Zhong L.L., 2015. Tectono-stratigraphic framework and Palaeozoic evolution of the Chinese South Tianshan. Geotectonics 49 (2), 93-122

Alexeiev, D.V., Bykadorov, V.A., Volozh, Yu.A., Sapozhnikov, R.B., 2017. Kinematic analysis of Jurassic grabens of Southern Turgai and the role of the Mesozoic stage in the evolution of the Karatau-Talas-Ferghana strike-slip fault, Southern Kazakhstan and Tian Shan. Geotectonics, 51 (2), 105-120.

Alexeiev, D. V., Cook, H. E., Djenchuraeva, A. V., Mikolaichuk, A. V., 2017b. The stratigraphic, sedimentological and structural evolution of the southern margin of the Kazakhstan continent in the Tien Shan Range during the Devonian to Permian. In: Brunet, M.F., McCann, T. Sobel, E. R. (Eds.), Geological Evolution of Central Asian Basins and the Western Tien Shan Range. Geological Society, London, Special Publications, 427. 
Allegre, C. O., Courtillot, V., Tapponnier, P., Hirn, A., Mattauer, M., Coulon, C., ... and Burg, J. P., 1984. Structure and evolution of the Himalaya-Tibet orogenic belt. Nature, 307(5946), 17.

Allen, M. B., and Natal'in, B. A., 1995. Junggar, Turfan and Alakol basins as Late Permian to? Early Triassic extensional structures in a sinistral shear zone in the Altaid orogenic collage, Central Asia. Journal of the Geological Society, 152 (2), 327-338.

Allen, M.B., Windley, B.F., Chi, Z., Zhong-Yan, Z., Guang-Rei, W., 1991. Basin evolution within and adjacent to the Tien Shan Range, NW China. Journal of Geological Society, London, 148, 369-378.

Allen, M.B., Alsop, G.I., Zhemchuzhnikov, V.G., 2001. Dome and basin refolding and transpressive inversion along the Karatau fault System, southern Kazakstan. Journal of the Geological Society of London, 158, 83-95.

Al-Qaraafi, F. A., and Guangqing, Y., 2013. Sand Body Description for Upper Sangonghe Formation (Early Jurassic), Baolang Oilfield, Yanqi Basin Northwest China. International Journal of Chemical Engineering and Applications, 4 (1), 26.

Ashraf, A. R., Sun, Y., Sun, G., Uhl, D., Mosbrugger, V., Li, J., Herrmann, M., 2010. Triassic and Jurassic palaeoclimate development in the Junggar Basin, Xinjiang, Northwest China - a review and additional lithological data. Palaeobiodiversity and Palaeoenvironments, 90 (3), 187-201.

Atlas of Geological Maps of Central Asia and Adjacent Areas (AGMCA). Geological Map 1: 2500 000, Beijing: Geological Publishing House, 2008. 
Avouac, J. P., Tapponnier, P., Bai, M., You, H., Wang, G., 1993. Active Thrusting and 1173 Folding Along the Northern Tien Shan and Late Cenozoic Rotation of the Tarim Relative to Dzungaria and Kazakhstan. Journal of Geophysical. Research, 98, 6755-6804.

1175

1176

1177

1178

1179

1180

1181

1182

1183

1184

1185

1186

1187

1188

1189

1190

1191

1192

1193

Bande, A., Radjabov, S., Sobel, E. R., Sim, T., 2015. Cenozoic palaeoenvironmental and tectonic controls on the evolution of the northern Fergana Basin. Geological Society London, Special Publications, 427.

Bazhenov M.L., Burtman V.S., Dvorova A.V., 1999. Permian paleomagnetism of the Tien Shan fold belt, Central Asia: post-collisional rotations and deformation. Tectonophysics 312, 303-329.

Bazhenov M.L. and Mikolaichuk A.V., 2004. Structural evolution of Central Asia to the north of Tibet: a synthesis of paleomagnetic and geological data. Geotectonics 38 (5), 379-393.

Bian, W., Hornung, J., Liu, Z., Wang, P., Hinderer, M., 2010. Sedimentary and palaeoenvironmental evolution of the Junggar Basin, Xinjiang, Northwest China. Palaeobiology Palaeoenvironment, 90, 175-186.

Blair, T. C. and McPherson, J. G., 1994. Alluvial fans and their natural distinction from rivers based on morphology, hydraulic processes, sedimentary processes and facies assemblages. Journal of Sedimentary Research, 64, 450-489.

Brookfield, M. E., and Hashmat, A., 2001. The geology and petroleum potential of the North Afghan platform and adjacent areas (northern Afghanistan, with parts of southern Turkmenistan, Uzbekistan and Tajikistan). Earth-Science Reviews, 55(1), 41-71.

Brunet, M. F., Korotaev, M. V., Ershov, A. V., Nikishin, A. M., 2003. The South Caspian Basin: a review of its evolution from subsidence modelling. Sedimentary Geology, 156 (1), 119-148. 
Brunet, M. F., Ershov, A. V., Korotaev, M. V., Melikhov, V. N., Barrier, E., Mordvintsev, D. O., Sidorova, I. P., 2017. Late Palaeozoic and Mesozoic evolution of the Amu Darya Basin (Turkmenistan, Uzbekistan). Geological Society, London, Special Publications, 427 (1), 89144.

Burbank, D. W., McLean, J. K., Bullen, M., Abdrakhmatov, K. Y., Miller, M. M., 1999. Partitioning of intermontane basins by thrust-related folding, Tien Shan, Kyrgyzstan. Basin Research, 11(1), 75-92.

Burtman, V. S. (1980). Faults of middle Asia. American Journal of Science, 280 (8), 725-744.

Buslov, M. M., Fujiwara, Y., Iwata, K., and Semakov, N. N., 2004. Late paleozoic-early Mesozoic geodynamics of Central Asia. Gondwana Research, 7(3), 791-808.

Carroll, A. R., Yunhai, L., Graham, S. A., Xuchang, X., Hendrix, M. S., Jinchi, C., McKnight, C. L., 1990. Junggar basin, northwest China: trapped Late Paleozoic ocean. Tectonophysics, $181(1), 1-14$.

Carroll, A. R., Graham, S. A., Hendrix, M. S., Ying, D., Zhou, D., 1995. Late Paleozoic tectonic amalgamation of northwestern China: sedimentary record of the northern Tarim, northwestern Turpan, and southern Junggar basins. Geological Society of America Bulletin, 107 (5), 571-594.

Charvet, J., Shu, L., Laurent-Charvet, S., Wang, B., Faure, M., Cluzel, D., Chen, Y., De Jong, K., 2011, Palaeozoic tectonic evolution of the Tianshan belt, NW China: Science China Earth Sciences, 54 (2), 166-184.

Charvet, J., Shu, L. S., Laurent-Charvet, S., 2007. Paleozoic structural and geodynamic evolution of eastern Tianshan (NW China): welding of the Tarim and Junggar plates. Episodes Journal of International Geoscience, 30 (3), 162-186. 
Chen, C., Lu, H., Jia, D., Cai, D., Wu, S., 1999. Closing history of the southern Tianshan oceanic basin, western China: an oblique collisional orogeny. Tectonophysics, 302, 23-40.

Clarke, J.W., 1984. Geology and possible uranium deposits of the Fergana region of Soviet Central Asia: United States Geological Survey Open-File Report, 84-513.

Cogné, J. P., Kravchinsky, V. A., Halim, N., Hankard, F., 2005. Late Jurassic-Early Cretaceous closure of the Mongol-Okhotsk Ocean demonstrated by new Mesozoic palaeomagnetic results from the Trans-Baikal area (SE Siberia). Geophysical Journal International, 163(2), 813-832.

Daoudene, Y., Gapais, D., Ledru, P., Cocherie, A., Hocquet, S., Donskaya, T. V., 2009. The Ereendavaa Range (north-eastern Mongolia): an additional argument for Mesozoic extension throughout eastern Asia. International Journal of Earth Sciences, 98 (6), 1381-1393.

Daoudene, Y., Gapais, D., Cogné, J. P., Ruffet, G., 2017. Late Jurassic-Early Cretaceous continental extension in northeast Asia-Relationships to plate kinematics. Bulletin de la Société géologique de France, 188 (1-2), 1-16.

De Grave, J., Buslov, M.M., Van den haute, P., 2007. Distant effects of India-Eurasia convergence and Mesozoic intracontinental deformation in Central Asia: Constraints from apatite fission-track thermochronology. Journal of Asian Earth Sciences, 29, 188-204.

De Grave, J., Glorie, S., Buslov, M. M., Izmer, A., Fournier-Carrie, A., Batalev, V. Y., Vanhaecke, F., Elburg, M., Van den haute, P., 2011. The thermo-tectonic history of the SongKul plateau, Kyrgyz Tien Shan: constraints by apatite and titanite thermochronometry and zircon U/Pb dating. Gondwana Research, 20, 4, 745-763

De Grave, J., Glorie, S., Ryabinin, A., Zhimulev, F. Izmer, A., Buslov, M.M., Elburg, M., Vanhaeke, F., Van den haute, P., 2012. Late Palaeozoic and Meso-Cenozoic tectonic 
evolution of the Southern Kyrgyz Tien Shan: constraints from multi-method thermochronology in the Trans-Alai, Turkestan-Alai Section and the Southeastern Ferghana Basin. Journal of Asian Earth Sciences, 44, 149-168.

De Grave, J., Glorie, S., Buslov, M. M., Stockli, D. F., McWilliams, M. O., Batalev, V. Y., 2013. Thermo-tectonic history of the Issyk-Kul basement (Kyrgyz northern Tien Shan, Central asia). Gondwana Research, 23 (3), 998-1020.

Deng, S., Yuanzhzen, L., Ru, F., Yanhong, P., Xiansheng, C., Guobin, F., Qifei, W., Huazhang, P., Yanbin, S., Yaqiong, W., Haichun, Z., Chengkai, J., Wenzhe, D., Linhao, F., 2010. The Jurassic System of Northern Xinjiang, China. University of Science and Technology of China Press, 279 pp.

Dengfa, H., Xinfa, C., Kuang, J., Lu, Z., Yong, T., Deguang, L., 2008. Development and genetic mechanism of Chepaizi-Mosuowan uplift in Junggar Basin, China. Earth Science Frontiers, 15 (4), $42-55$.

De Pelsmaeker, E., Jolivet, M., Laborde, A., Poujol, M., Robin, C., Zhimulev, F. I., Nachtergaele, S., Glorie, S., De Clercq, S., Batalev, V. Y., De Grave, J., 2018. Source-to-sink dynamics in the Kyrgyz Tien Shan from the Jurassic to the Paleogene: Insights from sedimentological and detrital zircon U-Pb analyses. Gondwana Research, 54, 180-204.

Desheng, L., Digang, L., Chengzao, J., Gang, W., Qizhi, W., Dengfa, H., 1996. Hydrocarbon accumulations in the Tarim basin, China. AAPG bulletin, 80 (10), 1587-1603.

Donskaya, T. V., Windley, B. F., Mazukabzov, A. M., Kröner, A., Sklyarov, E. V., Gladkochub, D. P., ... and Hegner, E., 2008. Age and evolution of late Mesozoic metamorphic core complexes in southern Siberia and northern Mongolia. Journal of the Geological Society, 165 (1), 405-421. 
Donskaya, T. V., Gladkochub, D. P., Mazukabzov, A. M., Ivanov, A. V., 2013. Late

1265

1266

1267

1268

1269

1270

1271

1272

1273

1274

1275

1276

1277

1278

1279

1280

1281

1282

1283

1284

1285

1286

Paleozoic-Mesozoic subduction-related magmatism at the southern margin of the Siberian continent and the 150 million-year history of the Mongol-Okhotsk Ocean. Journal of Asian Earth Sciences, 62, 79-97.

Dumitru, T. A., Zhou, D., Chang, E. Z., Graham, S. A., Hendrix, M. S., Sobel, E. R., Carroll, A. R., 2001. Uplift, exhumation, and deformation in the Chinese Tian Shan: MemoirsGeological Society of America 114, 71-100.

Eberth, D.A., Brinkman, D.B., Chen, P.-J., Yuan, F.-T., Wu, S.-Z., Li, G., Cheng, X.-S., 2001. Sequence stratigraphy, paleoclimate patterns, and vertebrate fossil preservation in Jurassic-Cretaceous strata of the Junggar Basin, Xinjiang Autonomous Region, People's Republic of China. Canadian Journal of Earth Sciences, 38(12), 1627-1644.

Enkin, R. J., Courtillot, V., Leloup, P., Yang, Z., Xing, L., Zhang, J., Zhuang, Z., 1992. The paleomagnetic record of uppermost Permian, Lower Triassic rocks from the south China block. Geophysical research letters, 19(21), 2147-2150.

Fedorenko, O.A., Miletenko, N.V. (Coordinators) 2002. Atlas of the lithologypaleogeographical, structural, palinspastic and geo-environmental maps of Central Eurasia. Center for geoinformation support of the military forces of Kazakhstan Republic, Almaty.

Feng, Y., Jiang, S., Wang, C., 2015. Sequence stratigraphy, sedimentary systems and petroleum plays in a low-accommodation basin: Middle to upper members of the Lower Jurassic Sangonghe Formation, Central Junggar Basin, Northwestern China. Journal of Asian Earth Sciences, 85-103.

Gao, J., Li, M., Xiao, X., Tang, Y., He, G., 1998. Paleozoic tectonic evolution of the Tianshan orogen, northwestern China. Tectonophysics, 287, 213-231. 
1287 Gao, C., Ji, Y., Ren, Y., Zhou, Y., Jin, J., Zhang, L., Li, Z., Zhou, Y., Wu, H., 2017.

1288 Geomorphology and sedimentary sequence evolution during the buried stage of paleo-uplift in 1289 the Lower Cretaceous Qingshuihe Formation, Junggar Basin, northwestern China: 1290 Implications for reservoir lithofacies and hydrocarbon distribution. Marine and Petroleum 1291 Geology, 86, 1224-1251.

1292

1293

1294

1295

1296

1297

1298

1299

1300

1301

1302

1303

1304

1305

1306

1307

1308

1309

Glorie, S., De Grave, J., Buslov, M. M., Zhimulev, F. I., Stockli, D. F., Batalev, V. Y., Izmer, A., Van den Haute, P., Vanhaecke, F., Elburg, M. A., 2011. Tectonic history of the Kyrgyz South Tien Shan (Atbashi-Inylchek) suture zone: The role of inherited structures during deformation-propagation. Tectonics, 30, 6 .

Glorie, S. and De Grave, J., 2016. Exhuming the Meso-Cenozoic Kyrgyz Tienshan and Siberian Altai-Sayan: A review based on low-temperature thermochronology. Geoscience Frontiers, 7, 155-170.

Graham, S. A., Hendrix, M. S., Johnson, C. L., Badamgarav, D., Badarch, G., Amory, J., ... and Hacker, B. R. ,2001. Sedimentary record and tectonic implications of Mesozoic rifting in southeast Mongolia. Geological Society of America Bulletin, 113 (12), 1560-1579.

Greene, T. J., Carroll, A. R., Hendrix, M. S., Graham, S. A., Wartes, M. A., Abbink, O. A., 2001. Sedimentary record of Mesozoic deformation and inception of the Turpan-Hami basin, northwest China. MEMOIRS-GEOLOGICAL SOCIETY OF AMERICA, 317-340.

Hasiotis, S. T., 2006. Continental Trace Fossils. Society of Economic Paleontologists and Mineralogists (SEPM), Short Courses, 51.

Hasiotis, S. T., Kraus, M. J., Demko, T. M., 2007. Climatic controls on continental track fossils. In: Miller, W. (Eds.) Trace Fossils Concepts, Problems, Prospects. Elsevier, Berlin, $172-195$. 
Heilbronn, G., Boulvais, P., Marchand, E., Robin, C., Bourquin, S., Barrier, L., Jia, Y., Fu, B., Jolivet, M., 2015. Stable isotope characterization of pedogenic and lacustrine carbonates from the Chinese Tian Shan: constraints on the Mesozoic-Lower Cenozoic palaeoenvironmental evolution. Chemie der Erde-Geochemistry, 75 (1), 133-141.

Hendrix, M. S., Graham, S. A., Carroll, A., Sobel, E., McKnight, C., Schulein, B., Wang, Z., 1992. Sedimentary record and climatic implications of recurrent deformation in the Tian Shan: evidence from Mesozoic strata of the north Tarim, south Dzungar, and Turpan basin, northwest China: Geological Society of America Bulletin, 104, 53-79.

Huang, W. L., Yang, X. P., Li, A., Pierce, I. K., Thompson, J. A., Angster, S. J., Zhang, L., 2015. Late Pleistocene shortening rate on the northern margin of the Yanqi Basin, southeastern Tian Shan, NW China. Journal of Asian Earth Sciences, 112, 11-24.

Hunter, R. E., 1977. Basic types of stratification in small eolian dunes. Sedimentology, 24, $361-387$.

Jia, Y., Fu, B., Jolivet, M., Zheng, S., 2015. Cenozoic tectono-geomorphological growth of the SW Chinese Tian Shan: Insight from AFT and detrital zircon U-Pb data. Journal of Asian Earth Sciences, 111, 395-413.

Ji, H., Tao, H., Wang, Q., Qiu, Z., Ma, D., Qiu, J., Liao, P., 2017. Early to Middle Jurassic tectonic evolution of the Bogda Mountains, Northwest China: Evidence from sedimentology and detrital zircon geochronology. Journal of Asian Earth Sciences.

Johnson, C. L., 2004. Polyphase evolution of the East Gobi basin: sedimentary and structural records of Mesozoic-Cenozoic intraplate deformation in Mongolia. Basin Research, 16 (1), 79-99. 
Jolivet, M., Dominguez, S., Charreau, J., Chen, Y., Li, Y., Wang, Q., 2010. Mesozoic and Cenozoic tectonic history of the Central Chinese Tian Shan: reactivated tectonic structures and active deformation: Tectonics, 29, TC 6019.

Jolivet, M., Bourquin, S., Heilbronn, G., Robin, C., Barrier, C., Dabard, M.-P., Jia, Y., De Pelsmaeker, E., Fu, B., 2017a. The Upper Jurassic-Lower Cretaceous alluvial-fan deposits of the Kalaza Formation (Central Asia): tectonic pulse or increased aridity? In: Brunet, M.F., McCann, T. Sobel, E. R. (Eds.), Geological Evolution of Central Asian Basins and the Western Tien Shan Range. Geological Society, London, Special Publications, 427.

Jolivet, M., Arzhannikova, A., Frolov, A., Arzhannikov, S., Kulagina, N., Akulova, V., Vassallo, R., 2017b. Late Jurassic-Early Cretaceous paleoenvironmental evolution of the Transbaikal basins (SE Siberia): implications for the Mongol-Okhotsk orogeny. Bulletin de la Société géologique de France, 188(1-2), 1-22.

Jolivet, M., 2017c. Mesozoic tectonic and topographic evolution of Central Asia and Tibet: a preliminary synthesis. Geological Society, London, Special Publications, 427 (1), 19-55.

Kapp, P., DeCelles, P. G., Gehrels, G. E., Heizler, M., Ding, L., 2007. Geological records of the Lhasa-Qiangtang and Indo-Asian collisions in the Nima area of central Tibet. Geological Society of America Bulletin, 119 (7-8), 917-933.

Klappa, C.F., 1980. Rhizolites in terrestrial carbonates: classification, recognition, genesis and significance. Sedimentology, 27, 613-627.

Kocureck, G. and Nielson, J. 1986. Conditions favourable for the formation of warm-climate aeolian sand sheets. Sedimentology, 33, 795-816.

Kraus, M.J., 1999. Paleosols in clastic sedimentary rocks: their geologic applications. Earth Science Reviews, 47, 41-70. 
Lasovskiy A. G., Mozolev L. N., 1961. Geology map of USSR, sheet K 43-XXI, scale 1:200 000, Northern Tian-Shan series.

Laurent-Charvet, S., Charvet, J., Shu, L., Ma, R., Lu, H., 2002. Palaeozoic late collisional strike-slip deformations in Tianshan and Altay, Eastern Xinjiang, NW China. Terra Nova, 14 (4), 249-256.

Lee, K. Y., 1985a, Geology of the petroleum and coal deposits in the Junggar (Zhungaer) basin, Xinjiang Uygur Zizhiqu, northwest China: U.S. Geological Survey Open-File Report 85-0230, p. 53.

Lee, K. Y., 1985b, Geology of the Tarim basin with special emphasis on petroleum deposits, Xinjiang Uygur Zizhiqu, northwest China: U.S. Geological Survey Open-File Report 85-616, p. 55 .

Le Heron, D. P., Buslov, M. M., Davies, C., Richards, K., Safonova, I., 2008. Evolution of Mesozoic fluvial systems along the SE flank of the West Siberian Basin, Russia. Sedimentary Geology, 208 (1-2), 45-60.

Lianhua, H., Jinghong, W., Kuang, L., Zhang, G., Lei, L. I. U., Kuang, J., 2009. Provenance sediments and its exploration significance-A case from member 1 of Qingshuihe formation of Lower Cretaceous in Junggar Basin. Earth Science Frontiers, 16 (6), 337-348.

Li, Z., Song, W., Peng, S., Wang, D., Zhang, Z., 2004. Mesozoic-Cenozoic tectonic relationships between the Kuqa subbasin and Tian Shan, northwest China: constraints from depositional records. Sedimentary Geology, 172 (3), 223-249.

Li, Z., Peng, S., 2010. Detrital zircon geochronology and its provenance implications: responses to Jurassic through Neogene basin-range interactions along northern margin of the Tarim Basin, Northwest China. Basin Research, 22, 126-138. 
Li, B., Zhuang, X., Li, J., Zhao, S., 2014. Geological controls on coal quality of the Yili Basin, Xinjiang Northwest China. International Journal of Coal Geology, 131, 186-199.

Li, D., He, D., Tang, Y., Wu, X., Lian, Y., Yang, Y., 2015. Dynamic processes from plate subduction to intracontinental deformation: Insights from the tectono-sedimentary evolution of the Zhaosu-Tekesi Depression in the southwestern Chinese Tianshan. Journal of Asian Earth Sciences, 113, 728-747.

Lin, B., Zhang, X., Xu, X., Yuan, J., Neng, Y., Zhu, J., 2015. Features and effects of basement faults on deposition in the Tarim Basin. Earth-Science Reviews, 145, 43-55.

Lin, C., Yang, H., Liu, J., Rui, Z., Cai, Z., Zhu, Y., 2012. Distribution and erosion of the Paleozoic tectonic unconformities in the Tarim Basin, Northwest China: significance for the evolution of paleo-uplifts and tectonic geography during deformation. Journal of Asian Earth Sciences, 46, 1-19.

Liu, D., Jolivet, M., Yang, W., Zhang, Z., Cheng, F., Bei, Z., Guo, Z., 2013. Latest PaleozoicEarly Mesozoic basin-range interactions in South Tian Shan (northwest China) and their tectonic significance: Constraints from detrital zircon $\mathrm{U}-\mathrm{Pb}$ ages. Tectonophysics, 599, 197213.

Liu, D., Guo, Z., Jolivet, M., Cheng, F., Song, Y., Zhang, Z., 2014. Petrology and geochemistry of Early Permian volcanic rocks in South Tian Shan, NW China: implications for the tectonic evolution and Phanerozoic continental growth. International Journal of Earth Sciences, 103 (3), 737-756.

Liu D., Cheng F., Guo Zh., Jolivet M., Song Y., 2015. Lahar facies of the latest Paleozoic Arbasay Formation: Geomorphological characters and paleoenvironment reconstruction of Northern Tian Shan, NW China. Journal of Asian Earth Sciences, 113, 282-292. 
Liu, Y. J., Neubauer, F., Genser, J., Ge, X. H., Takasu, A., Yuan, S. H., Chang, L. H., Li, W. M., 2007. Geochronology of the initiation and displacement of the Altyn Strike-Slip Fault, western China. Journal of Asian Earth Sciences, 29 (2-3), 243-252.

Ma, D., He, D., Li, D., Tang, J., Liu, Z., 2015. Kinematics of syn-tectonic unconformities and implications for the tectonic evolution of the Hala'alat Mountains at the northwestern margin of the Junggar Basin, Central Asian Orogenic Belt. Geoscience Frontiers, 6 (2), 247-264.

Macaulay, E. A., Sobel, E. R., Mikolaichuk, A., Kohn, B., Stuart, F. M., 2014. Cenozoic deformation and exhumation history of the Central Kyrgyz Tien Shan. Tectonics, 33 (2), 135165.

Mattauer, M., Malavieille, J., Calassou, S., Lancelot, J., Roger, F., Hao, Z. W., ... and Hou, L. W., 1992. The Songpan-Garze Triassic belt of west Sechuan and eastern Tibet: A decollement fold belt on passive margin. Comptes rendu de l'Académie des sciences. Serie II, 314 (6), 619-626.

Matte, P., Tapponnier, P., Arnaud, N., Bourjot, L., Avouac, J. P., Vidal, P., Qing, L., Yusheng, P., Yi, W., 1996. Tectonics of Western Tibet, between the Tarim and the Indus. Earth and Planetary Science Letters, 142 (3-4), 311-330.

Metcalfe, I., 2013. Gondwana dispersion and Asian accretion: tectonic and palaeogeographic evolution of eastern Tethys. Journal of Asian Earth Sciences, 66, 1-33.

Miall, A. D., 1978. Lithofacies types and vertical profile models in braided river deposits: a summary. In: Miall, A. D. (Eds.) Fluvial Sedimentology. Canadian Society Petroleum Geology, Memoirs, 5, 597-604.

Miall, A. D., 1996. The Geology of Fluvial Deposits. Springer, Berlin, 582 p. 
Moisan, P., Voigt, S., Pott, C., Buchwitz, M., Schneider, J. W., Kerp, H., 2011. Cycadalean and bennettitalean foliage from the Triassic Madygen Lagerstätte (SW Kyrgyzstan, central Asia). Review of Palaeobotany and Palynology, 164 (1), 93-108.

Molnar, P., Tapponnier, P., 1975. Cenozoic tectonics of Asia: effects of a continental collision: features of recent continental tectonics in Asia can be interpreted as results of the India-Eurasia collision. Science, 189, 419-426.

Mordvintsev, D., Barrier, E., Brunet, M. F., Blanpied, C., Sidorova, I., 2017. Structure and evolution of the Bukhara-Khiva region during the Mesozoic: the northern margin of the AmuDarya Basin (southern Uzbekistan). Geological Society, London, Special Publications, 427, SP427-16.

Moseley, B. A., and Tsimmer, V. A., 2000. Evolution and hydrocarbon habitat of the South Turgay Basin, Kazakhstan. Petroleum Geoscience, 6 (2), 125-136.

Mulder, T., and Alexander, J., 2001. The physical character of subaqueous sedimentary density flows and their deposits. Sedimentology, 48 (2), 269-299.

Nachtergaele, S., De Pelsmaeker, E., Glorie, S., Zhimulev, F., Jolivet, M., Danišík, M., Buslov, M.M., De Grave, J., 2018. Meso-Cenozoic tectonic evolution of the Talas-Fergana region of the Kyrgyz Tien Shan revealed by low-temperature basement and detrital thermochronology, Geoscience Frontiers, doi: 10.1016/j.gsf.2017.11.007.

Nikishin, A. M., Cloetingh, S. A. P. L., Brunet, M. F., Stephenson, R. A., Bolotov, S. N., Ershov, A. V., 1998. Scythian platform, Caucasus and Black Sea region: Mesozoic-Cenozoic tectonic history and dynamics. Peri-Tethys Memoir, 3, 163-176. 
Novikov, I. S., 2013. Reconstructing the stages of orogeny around the Junggar basin from the

1445 lithostratigraphy of Late Paleozoic, Mesozoic, and Cenozoic sediments. Russian Geology and 1446 Geophysics, 54(2), 138-152.

1447 Otto, S. C., 1997. Mesozoic-Cenozoic history of deformation and petroleum systems in 1448 sedimentary basins of Central Asia; implications of collisions on the Eurasian margin. 1449 Petroleum Geoscience, 3 (4), 327-341.

1450 Pan, Y., Sha, J., Wang, Y., Zhang, X., Yao, X., Peng, B., Rao, X., 2012. The brackish-water 1451 bivalve Waagenoperna from the Lower Jurassic Badaowan Formation of the Junggar Basin and its palaeoenvironmental and palaeogeographic significance. Geoscience Frontiers, 4, 951453103

1454

Postma, G., 1990. Depositional architecture and facies of river and fan deltas: a synthesis. In: Collela, A., Prior, D. B. (Eds.), Coarse-grained deltas. International Association of Sedimentologists, Special Publications, 10, 13-27.

Qin, K., Su, B. X., Sakyi, P. A., Tang, D. M., Li, X. H., Sun, H., Xiao, Q. H., Liu, P. P., 2011. SIMS zircon $\mathrm{U}-\mathrm{Pb}$ geochronology and $\mathrm{Sr}-\mathrm{Nd}$ isotopes of $\mathrm{Ni}-\mathrm{Cu}-$ Bearing Mafic-Ultramafic Intrusions in Eastern Tianshan and Beishan in correlation with flood basalts in Tarim Basin (NW China): Constraints on a ca. 280 Ma mantle plume. American Journal of Sciences 311, $237-260$.

Qiu, N. S., Zha, M.,Wang, X. L., Yang, H. B., 2005. Tectono-thermal evolution of the Junggar Basin, NW China: constraints from Ro and apatite fission track modelling, Petrol. Geosci., 11, 361-372. 
Reid, A.J., Wilson, C.J.L., Liu, S., 2005. Structural evidence for the Permo-Triassic tectonic

1466

1467

1468

1469

1470

1471

1472

1473

1474

1475

1476

1477

1478

1479

1480

1481

1482

1483

1484

1485

evolution of the Yidun arc, eastern Tibetan plateau. Journal of Structural Geology 27, 119137.

Retallack, G. J., 1997. A Colour Guide to Paleosols. John Wiley and Sons, Chichester, England.

Retallack, G.J., 1988. Field recognition of palaeosols. In: Reinhardt, J., Sigleo,W.R. (Eds.), Palaeosols and Weathering through Geologic Time; Principles and Applications: Geological Society of America Special Papers, 216, 1-20.

Ritts, B. D., Berry, A. K., Johnson, C. L., Darby, B. J., Davis, G. A., 2010. Early Cretaceous supradetachment basins in the Hohhot metamorphic core complex, Inner Mongolia, China. Basin Research, 22 (1), 45-60.

Robert, A. M., Letouzey, J., Kavoosi, M. A., Sherkati, S., Müller, C., Vergés, J., Aghababaei, A., 2014. Structural evolution of the Kopeh Dagh fold-and-thrust belt (NE Iran) and interactions with the South Caspian Sea Basin and Amu Darya Basin. Marine and Petroleum Geology, 57, 68-87.

Roger, F., Malavieille, J., Leloup, P.H., Calassou, S., Xu, Z., 2004. Timing of granite emplacement and cooling in the Songpan-Garzê fold belt (eastern Tibetan plateau) with tectonic implications. Journal of Asian Earth Sciences 22, 465-481.

Roger, F., Jolivet, M., and Malavieille, J., 2010. The tectonic evolution of the Songpan Garze (North Tibet) and adjacent areas from Proterozoic to Present: a synthesis. Journal of Asian Earth Sciences, 39, 254-269.

Roger, F., Jolivet, M., Cattin, R., Malavieille, J., 2011. Mesozoic-Cenozoic tectonothermal evolution of the eastern part of the Tibetan Plateau (Songpan-Garzê, Longmen Shan area): 
insights from thermochronological data and simple thermal modelling. Geological Society, London, Special Publications, 353(1), 9-25.

Rolland, Y., Alexeiev, D., Kroner, A., Corsini, M., Loury, C., Monie, P., 2013. Late

Palaeozoic to Mesozoic kinematic history of the Talas-Ferghana strike-slip fault (Kyrgyz

West Tianshan) as revealed by $40 \mathrm{Ar} / 39 \mathrm{Ar}$ dating of syn-kinematic white mica. Journal of

Asian Earth Sciences, 67-68, 76-92.

Schnyder, J., Pons, D., Yans, J., Tramoy, R., Abdulanova, S., 2016. Integrated stratigraphy of 1495

a continental Pliensbachian-Toarcian Boundary (Lower Jurassic) section at Taskomirsay,

Leontiev Graben, southwest Kazakhstan. Geological Society, London, Special

Publications, 427, SP427-15.

1498

Sengör, A.M.C., 1979. Tethys and its implications. Nature, 279 (14), 14.

Sengör, A.M.C., Natal'in, B.A., Burtman, V.S., 1993. Evolution of the Altaid Tectonic

1500

Collage and Paleozoic Crustal Growth in Eurasia. Nature, 364 (6435), 299-307.

1501

Sengör, A. M. C., 1996. Paleotectonics of Asia: fragments of a synthesis. The tectonic

1502 evolution of Asia, 486-640.

1503

1504

1505

1506

1507

1508

1509

Sha, J., Vajda, V., Pan, Y., Larsson, L., Yao, X., Zhang, X., Wang, Y., Cheng, X., Jiang, B., Deng, S., Chen, S., Peng, B., 2011. Stratigraphy of the Triassic-Jurassic boundary successions of the southern margin of the Junggar Basin, northwestern China. Acta Geologica Sinica, 85, 421-436.

Sha, J., Wang, Y., Pan, Y., Yao, X., Rao, X., Cai, H., Zhang, X., 2016. Temporal and spatial distribution patterns of the marine-brackish-water bivalve Waagenoperna in China and its implications for climate and palaeogeography through the Triassic-Jurassic transition. Palaeogeography, Palaeoclimatology, Palaeoecology, 464, 43-50. 
1511 Shao, L., Stattegger, K., Li, W., Haupt, B. J., 1999. Depositional style and subsidence history 1512 of the Turpan Basin (NW China). Sedimentary Geology, 128, 155-169.

1513 Shao, L., Zhang, P., Hilton, J., Gayer, R., Wang, Y., Zhao, C., Luo, Zh., 2003. 1514 Palaeoenvironments and Palaeogeography of the Lower and lower Middle Jurassic coal 1515 measures in the Turpan-Hami oil-prone coal basin, northwestern China. American 1516 Association of Petroleum Geology Bulletin, 87, 335-355.

1517 Shi, J., Jin, Z., Fan, T., Liu, Q., Zhang, F., Fan, X., 2016. Sequence development, depositional 1518 filling evolution, and prospect forecast in northern Aryskum Depression of South Turgay 1519 Basin, Kazakstan. Energy Exploration \& Exploitation, 34 (4), 621-642.

1520 Sobel, E. R., 1999. Basin analysis of the Jurassic-Lower Cretaceous southwest Tarim Basin, 1521 northwest China. Geological Society of America Bulletin, 111 (5), 709-724.

1522 Sobel, E. R., Arnaud, N., Jolivet, M., Ritts, B. D., Brunei, M., 2001. Jurassic to Cenozoic 1523 exhumation history of theAltyn Tagh range, northwest China, constrained by 40Ar/39Ar and 1524 apatite fission track thermochronology. Paleozoic and Mesozoic tectonic evolution of central 1525 and eastern Asia, 194, 247.

1526 Sobel, E. R., Oskin, M., Burbank, D., Mikolaichuk, A., 2006. Exhumation of basement-cored 1527 uplifts: Example of the Kyrgyz Range quantified with apatite fission track thermochronology. 1528 Tectonics, $25(2)$.

1529 Svendsen, J., Stollhofen, H., Krapf, C. B. E. Stanistreet, I. G., 2003. Mass and 1530 hyperconcentrated flow deposits record dune damming and catastrophic breakthrough of 1531 ephemeral rivers, Skeleton Coast Erg, Namibia. Sedimentary Geology, 160, 7-31. 
Tang, W., Zhang, Z., Li, J., Li, K., Chen, Y., Guo, Z., 2014. Late Paleozoic to Jurassic tectonic evolution of the Bogda area (northwest China): Evidence from detrital zircon $\mathrm{U}-\mathrm{Pb}$ geochronology. Tectonophysics, 626, 144-156.

Tang, W., Zhang, Z., Li, J., Li, K., Luo, Z., Chen, Y., 2015. Mesozoic and Cenozoic uplift and exhumation of the Bogda Mountain, NW China: Evidence from apatite fission track analysis. Geoscience Frontiers, 6 (4), 617-625.

Tapponnier, P., Zhiqin, X., Roger, F., Meyer, B., Arnaud, N., Wittlinger, G., Jingsui, Y., 2001. Oblique stepwise rise and growth of the Tibet Plateau. science, 294(5547), 1671-1677.

Thomas, J. C., Cobbold, P. R., Shein, V. S., Le Douaran, S., 1999. Sedimentary record of late Paleozoic to Recent tectonism in central Asia-analysis of subsurface data from the Turan and south Kazak domains. Tectonophysics, 313 (3), 243-263.

Van der Voo, R., Levashova, N.M., Skrinnik, L.I., Kara, T.V., Bazhenov, M.L., 2006. Late orogenic, large-scale rotations in the Tien Shan and adjacent mobile belts in Kyrgyzstan and Kazakhstan. Tectonophysics 426, 335-360.

Vincent, S. J. and Allen, M. B., 2001. Sedimentary record of Mesozoic intracontinental deformation in the eastern Junggar Basin, north-west China: response to orogeny at the Asian margin. In: Hendrix, M. S., Davis, G. A. (Eds) Palaeozoic and Mesozoic Tectonic Evolution of Central and Eastern Asia: from Continental Assembly to Intracontinental Deformation. Geological Society of America, Memoirs, 194, 341-360.

VNIGNI and Beicip Franlab., 1992. Petroleum potential of Central Asia, 2 volumes, Beicip Franlab, Rueil-Malmaison, France.

Wang B., Faure M., Cluzel D., Shu L.S., Charvet J., Meffre S., 2006. Late Paleozoic tectonic evolution of the northern West Tian Shan, NW China. Geodynamica Acta, 19 (3-4), 237-247. 
Wang, B., Chen, Y., Zhan, S., Shu, L., Faure, M., Cluzel, D., Charvet, J., Laurent-Charvet, S., 1556 2007a. Primary Carboniferous and Permian paleomagnetic results from the Yili Block (NW China) and their implications on the geodynamic evolution of Chinese Tianshan Belt. Earth and Planetary Science Letters 263, 288-308.

1559

1560

1561

1562

1563

Wang, B., Shu, L. S., Cluzel, D., Faure, M., Charvet, J., 2007b. Geochemical constraints on Carboniferous volcanic rocks of the Yili Block (Xinjiang, NW China): Implication for the tectonic evolution of Western Tianshan. Journal of Asian Earth Sciences 29, 148-159.

Wang B., Cluzel D., Shu L.S., Faure M., Charvet J., Chen Y., Meffre S., De Jong K., 2009. Evolution of calc-alkaline to alkaline magmatism through Carboniferous convergence to Permian transcurrent tectonics, western Chinese Tianshan. International Journal of Earth Science, 98, 1275-1298.

Wang, M., Zhang, J., Liu, K., 2015. Continuous denudation and pediplanation of the Chinese Western Tianshan orogen during Triassic to Middle Jurassic: Integrated evidence from detrital zircon age and heavy mineral chemical data. Journal of Asian Earth Sciences, 113 (1), 310324.

Wang, S. L., Shu, L. S., Zhu, W. B., Xu, M. J., Lu, H. F., Xiao, Z. Y., Luo, J-C., Zhu, C. J., 2012. Mesozoic faults in the NE Tarim (western China) and the implications on collisions in the southern Eurasian margin. Journal of Asian Earth Sciences, 56, 191-199.

Wartes, M.A, Carroll, A.R., Greene, T.D., 2002. Permian sedimentary record of the TurpanHami basin and adjacent regions, northwest China: Constraints on postamalgamation tectonic evolution. Geological Society of America Bulletin, 114 (2), 131-152. 
1576

1577

1578

1579

1580

1581

1582

1583

1584

1585

1586

1587

1588

1589

1590

1591

1592

1593

1594

1595

1596

Watson, M. P., Hayward, A. B., Parkinson, D. N., Zhang, Z. M., 1987. Plate tectonic history, basin development and petroleum source rock deposition onshore China. Marine and Petroleum Geology, 4 (3), 205-225.

Wilhem, C., Windley, B. F., Stampfli, G. M., 2012. The Altaids of Central Asia: a tectonic and evolutionary innovative review. Earth-Science Reviews, 113 (3), 303-341.

Windley, B.F., Alexeiev, D., Xiao, W., Kröner, A., Badarch, G., 2007. Tectonic models for the accretion of the Central Asion Orogenic Belt. Journal of the Geological Society of London, 164, 31-47.

Xia, L., Xu, X., Li, X., Ma, Z., Xia, Z., 2012. Reassessment of petrogenesis of Carboniferous-

Early Permian rift-related volcanic rocks in the Chinese Tianshan and its neighboring areas. Geoscience Frontiers, 3 (4), 445-471.

Xinjiang Bureau of Geology and Mineral Resources (XBGMR), Geological maps of the Bayanbulak area, scale 1:200,000, Geol. Publ. House, Beijing (1969).

Xinjiang Bureau of Geology and Mineral Resources (XBGMR), Geological maps of the Yaha area, scale 1:200,000, Geol. Publ. House, Beijing (1970).

Xinjiang Bureau of Geology and Mineral Resources (XBGMR), Geological maps of the Wusu area, scale 1:200,000, Geol. Publ. House, Beijing (1973a).

Xinjiang Bureau of Geology and Mineral Resources (XBGMR), Geological maps of the eastern Yili area, scale 1:200,000, Geol. Publ. House, Beijing (1973b).

Xinjiang Bureau of Geology and Mineral Resources (XBGMR), Geological maps of the Manas area, scale 1:200,000, Geol. Publ. House, Beijing (1978a). 
Xinjiang Bureau of Geology and Mineral Resources (XBGMR), Geological maps of the Urumqi area, scale 1:200,000, Geol. Publ. House, Beijing (1978b)

Yang, W., Jolivet, M., Dupont-Nivet, G., Guo, Z., Zhang, Z., Zhang, Z., 2013. Source to sink relations between the Tian Shan and Junggar Basin (northwest China) from Late Palaeozoic to Quaternary: evidence from detrital U-Pb zircon geochronology. Basin Research, 25, 219-240.

Yang, Y.-T., Song, C.-C., He, S., 2015. Jurassic tectonostratigraphic evolution of the Junggar basin, NW China: A record of Mesozoic intraplate deformation in Central Asia. Tectonics, 34, 86-115.

Yang, Y. T., Guo, Z. X., Luo, Y. J., 2017. Middle-Late Jurassic tectonostratigraphic evolution of Central Asia, implications for the collision of the Karakoram-Lhasa Block with Asia. Earth-Science Reviews, 166, 83-110.

Yin, A., 2010. Cenozoic tectonic evolution of Asia: A preliminary synthesis. Tectonophysics, 488 (1-4), 293-325.

Yu, X., Yang, S. F., Chen, H. L., Chen, Z. Q., Li, Z. L., Batt, G. E., Li, Y. Q., 2011. Permian flood basalts from the Tarim Basin, Northwest China: SHRIMP zircon U-Pb dating and geochemical characteristics. Gondwana Research 20, 485-497.

Yu, Y., Wang, X., Rao, G., Wang, R., 2016. Mesozoic reactivated transpressional structures and multi-stage tectonic deformation along the Hong-Che fault zone in the northwestern Junggar Basin, NW China. Tectonophysics, 679, 156-168.

Yuan, W., Carter, A., Dong, J., Bao, Z., An, Y., Guo, Z., 2006. Mesozoic-Tertiary exhumation history of the Altai Mountains, northern Xinjiang, China: new constraints from apatite fission track data. Tectonophysics, 412 (3), 183-193. 
Zhang, Z., Guo, Z., Han, Z., 1998. Geochemistry and geological significance of the midJurassic volcanic rocks in Dunhuang Basin. ACTA SCIENTIARUM NATURALIUMUNIVERSITATIS PEKINENSIS, 34, 72-79.

Zhao, S., Li, S., Liu, X., Suo, Y., Dai, L., Lou, D., Sun, W., Li, T., Wang, X., Yang, Z., 2014. Intracontinental orogenic transition: Insights from structures of the eastern Junggar Basin between the Altay and Tianshan orogens. Journal of Asian Earth Sciences, 88, 137-148.

Zonenshain, L. P., and Pichon, X., 1986. Deep basins of the Black Sea and Caspian Sea as remnants of Mesozoic back-arc basins. Tectonophysics, 123 (1-4), 181-211.

Zorin, Y. A., 1999. Geodynamics of the western part of the Mongolia-Okhotsk collisional belt, Trans-Baikal region (Russia) and Mongolia. Tectonophysics, 306 (1), 33-56.

\section{FIGURES CAPTIONS:}

Fig. 1. General topography and tectonic framework of the Tian Shan region. The locations of the sedimentological sections are indicated by red stars and white circles: T-K, Tash-Kumir; J-D, Jetim-Dobo; Te, Terek; Ku, Kuzigongsu; M-K, Ming-Kush; K-S, Kadji-Sai; J-O, JetiOguz; Ya, Yaha; Ba, Bayanbulak; Ni, Nieleke; Wu, Wusu; Ma, Manas; To, Toutunhe (north and south); Ai, Aiwergou; Ke, Kerjan; Ta, Taoshuyan; Ke, Kelameili; Ka, Karamay. TFF, Talas-Fergana fault; DNF = Dzhalair - Naiman Fault; NTSF, North Tian Shan fault. Y-F B, Yarkand-Fergana Basin; Bay. B., Bayanulak Basin.

Fig. 2. Synthesis of the chronostratigraphic charts available for the Jurassic to Early Cretaceous series in the Junggar, Tarim and Fergana basins. 
Fig. 3. Pictures illustrating the various Jurassic sedimentary facies of the Tian Shan region. See Table. 1 for the facies codes and descriptions. Pictures of facies respectively from: F1, Toutunhe Fm (Wusu section); F2, Xishanyao Fm (Wusu section); F3, Kalemake Fm (Yaha section); F4, F7 Qigu Fm, (Yaha and South Toutunhe sections); F5, Kalemake Fm (Yaha section); F6, Kezilenuer Fm (Yaha section)

Fig. 4. Pictures illustrating the various Jurassic sedimentary facies of the Tian Shan region. See Table. 1 for the facies codes and descriptions. Pictures of facies respectively from: F7, Qigu Fm (Yaha section), F8, Qigu Fm (South Toutunhe section) F9, respectively from Yengisar Fm (Yaha section), Toutunhe Fm (Nieleke section); F4, F10, Kalaza Fm (South Toutunhe section); F11, Kalaza Fm (Yaha section); F12, Kalaza Fm (Manas section); F13, Xishanyao Fm (Wusu section).

Fig. 5. Pictures illustrating the various Jurassic pedogenic and alteration features encountered within the Tian Shan region. See Table. 2 for facies codes and descriptions. Pictures of pedogenic features respectively from: P1, Yengisar Fm (Yaha section); P2, Kalaza Fm (Manas section), P3, Qigu Fm (Wusu section); P4, Qigu Fm (Wusu and Yaha sections); P5 (Bayanbulak section)

Fig. 6. Sedimentary log of the South Toutunhe section in the south Junggar Basin. Associated facies assemblages and their interpretation in term of depositional environments as in Table. 3.

Fig. 6 bis. Graphical caption presenting the various symbols used in Figs 6-12.

Fig. 7. Sedimentary log of the North Toutunhe section in the south Junggar Basin. Symbols as in Fig. 6. Associated facies assemblages and their interpretation in term of depositional environments as in Table. 3. 
Fig. 8. Sedimentary log of the Manas section in the south Junggar Basin. Symbols as in Fig. 6. Associated facies assemblages and their interpretation in term of depositional environments as in Table. 3.

Fig. 9. Sedimentary log of the Wusu section in the south Junggar Basin. Symbols as in Fig. 6. Associated facies assemblages and their interpretation in term of depositional environments as in Table. 3.

Fig. 10. Sedimentary log of the Nieleke section in the Yili Basin. Symbols as in Fig. 6. Associated facies assemblages and their interpretation in term of depositional environments as in Table. 3 .

Fig. 11. Sedimentary log of the Bayanbulak section in the Bayanbulak Basin. Symbols as in Fig. 6. Associated facies assemblages and their interpretation in term of depositional environments as in Table. 3.

Fig. 12. Sedimentary log of the Yaha section in the north Tarim Basin. Symbols as in Fig. 6 . Associated facies assemblages and their interpretation in term of depositional environments as in Table. 3.

Fig. 13. Early - early Middle Jurassic paleogeography of the Tian Shan region atop of the present-day topography; AB: Aksai Basin; BB: Bayanbulak Basin; FB: Fergana Basin; IB: Issyk-Kul Basin; MB: Ming Kush Basin; NB: Naryn Basin; TB: Turfan Basin; YB: Yili Basin; YFB; Yarkand-Fergana Basin; ZB: Zahosu Basin.

Fig. 14. Late Middle - early Late Jurassic paleogeography of the Tian Shan region atop of the present-day topography; AB: Aksai Basin; BB: Bayanbulak Basin; FB: Fergana Basin; IB: Issyk-Kul Basin; MB: Ming Kush Basin; NB: Naryn Basin; TB: Turfan Basin; YB: Yili Basin; YFB; Yarkand-Fergana Basin; ZB: Zahosu Basin. 
Fig. 15. Late Jurassic - Early Cretaceous paleogeography of the Tian Shan region atop of the present-day topography; AB: Aksai Basin; BB: Bayanbulak Basin; FB: Fergana Basin; IB: Issyk-Kul Basin; MB: Ming Kush Basin; NB: Naryn Basin; TB: Turfan Basin; YB: Yili Basin; YFB; Yarkand-Fergana Basin; ZB: Zahosu Basin.

Fig. 16. Synthetic chart of the Tian Shan region: stratigraphic record, thermochronology (Thermo.), topography, climate and geodynamic events.

Fig. 17. A. Late Early to Middle Jurassic paleogeography of the Asian continent (modified from Jolivet, 2017c); EU, European Craton; CIB, GCB; Great Caucasian Basin; SCB, South Caspian Basin; Central Iran Blocks; LH, Lhasa Block; QI, Qiangtang Block; SG, SongpanGarzê prism; Q, Qaidam Block; Mon, Mongolian Block; NC, North China Block; SC, South China Block; IND, Indochina Block; SIB, Sibumasu Block; WB, West Burma Block; TFF, Talas Fergana fault. B. Late Early to Middle Jurassic kinematic framework of the west Central Asia region. Regional Jurassic basins and main depocenters were derived from these studies; Lee (1985a, b); Thomas et al., (1999); Sobel et al., (1999); Fedorenko and Miletenko. (2002); Alexeiev et al., (2017). Tectonic structures were compiled from VNIGNI and Beicip Franlab., (1992); Thomas et al., (1999); Wang et al., (2012); Robert et al., (2014); Yang et al., (2015); Brunet et al., (2017). The location and the geometry of the subduction zone were derived from Brunet et al., (2017). ST: South Turgay Basin; LT: Leontiev Basin; YF: Yarkand Fergana Basin; B: Bayanbulak Basin; T: Turfan Basin; TFF: Talas Fergana/Karatau fault; NTSF: North Tian Shan fault; ATF: Altyn Tagh fault; 1, Paleotethys suture; 2, Turkestan suture; 3, Jinsha suture; 4, Kunlun suture. 


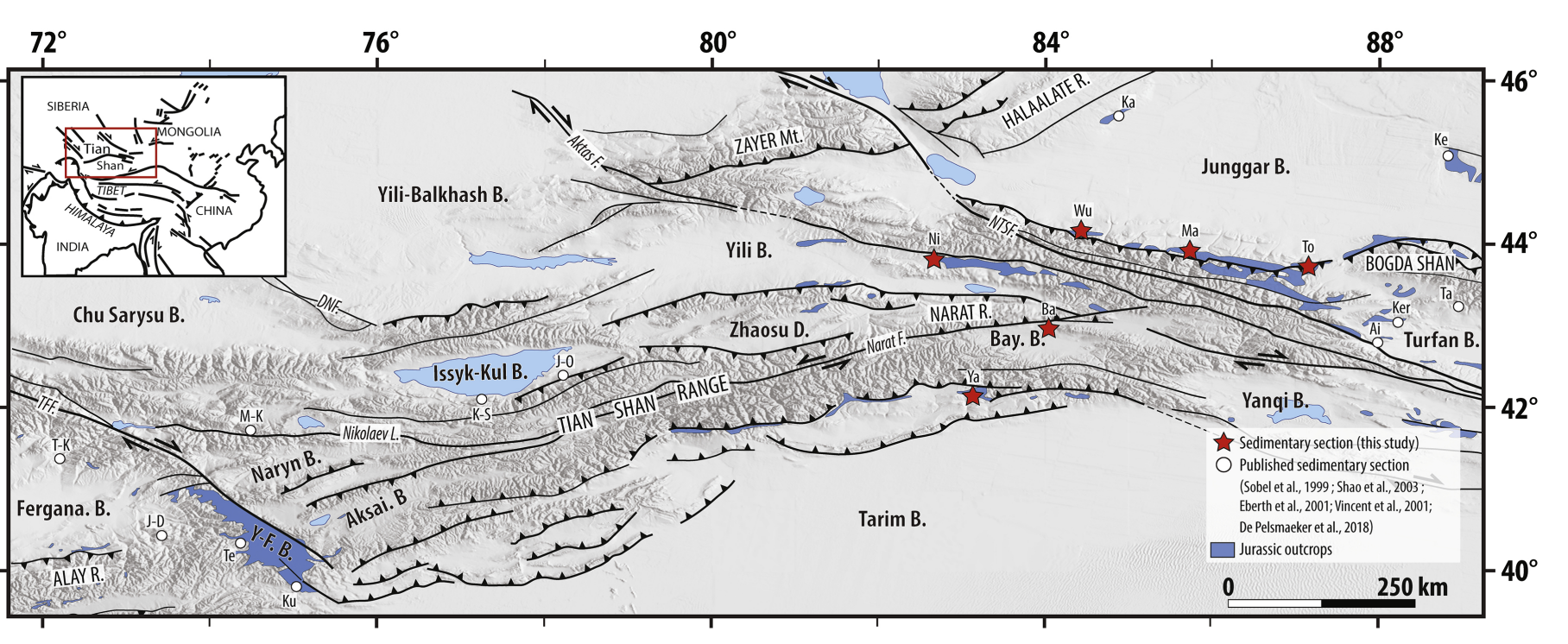

Figure 1 


\section{JUNGGAR B.}

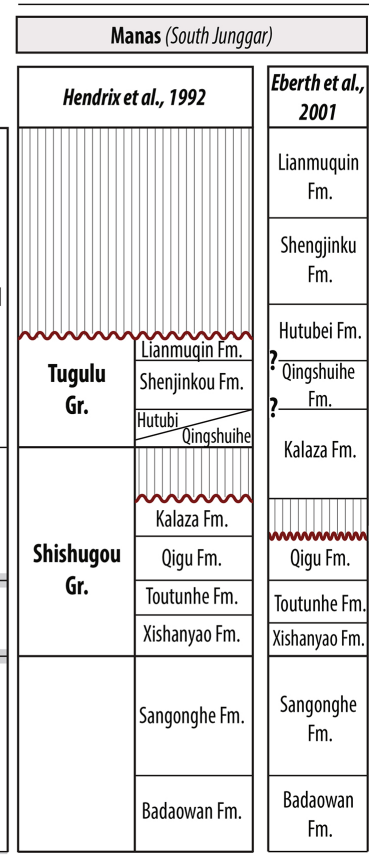

TARIM B.

\begin{tabular}{|l|l|}
\hline Kelameili (East Junggar) Karamay (West Junggar) \\
\hline
\end{tabular}
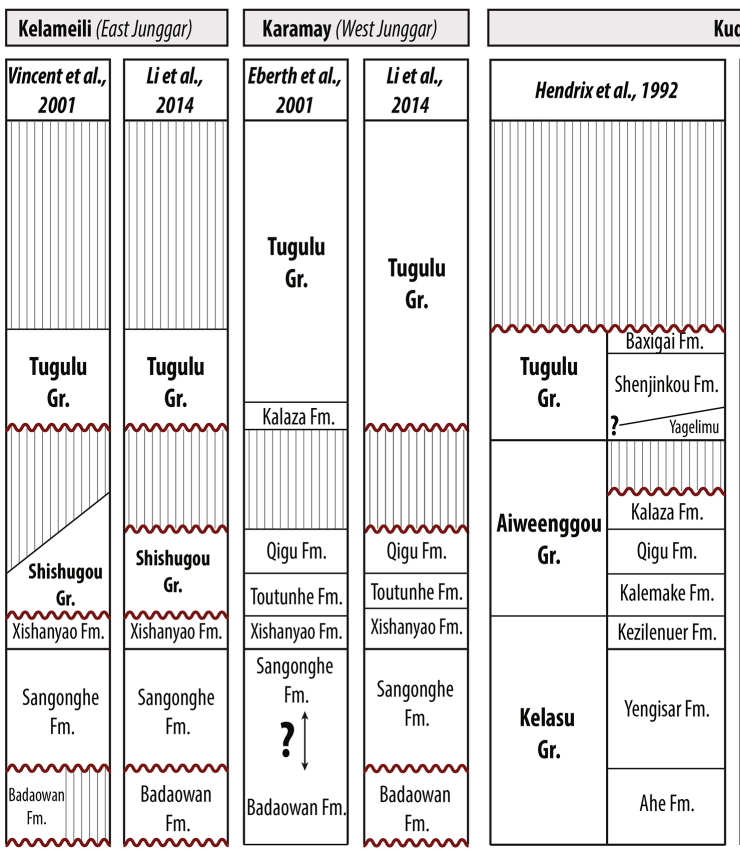

Kuqa

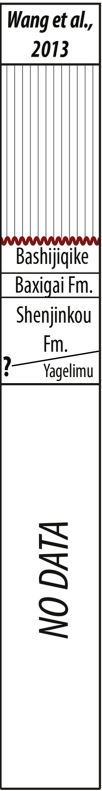

F. B.

Kuzigongsu

Tash Komyr

Sobel et al.,

De Pelsmaeker et al., 2017

$\frac{\pi}{\frac{1}{8}}$

Gr.

\begin{tabular}{|c|c|c|}
\hline Bashiijgike & & \\
\hline Baxigai Fm. & & \\
\hline Shushanhe Fm. & & \\
\hline Yagelimu & & Hodzhiabad \\
\hline Kalaza Fm. & Kuzigongsu & \\
\hline Qigu Fm. & & \\
\hline Qiakemake & Targa Fm. & Balabansay Fm. \\
\hline Kezilenuer & Yangye Fm. & Igrysay Fm. \\
\hline Yangxia Fm. & Kansu Fm. & $\begin{array}{c}\text { Tash Komyr } \\
\text { Fm. }\end{array}$ \\
\hline & $?$ & \\
\hline Ahe Fm. & $\begin{array}{c}\text { Shalitashi } \\
\text { Fm. }\end{array}$ & \\
\hline
\end{tabular}

Figure 2 

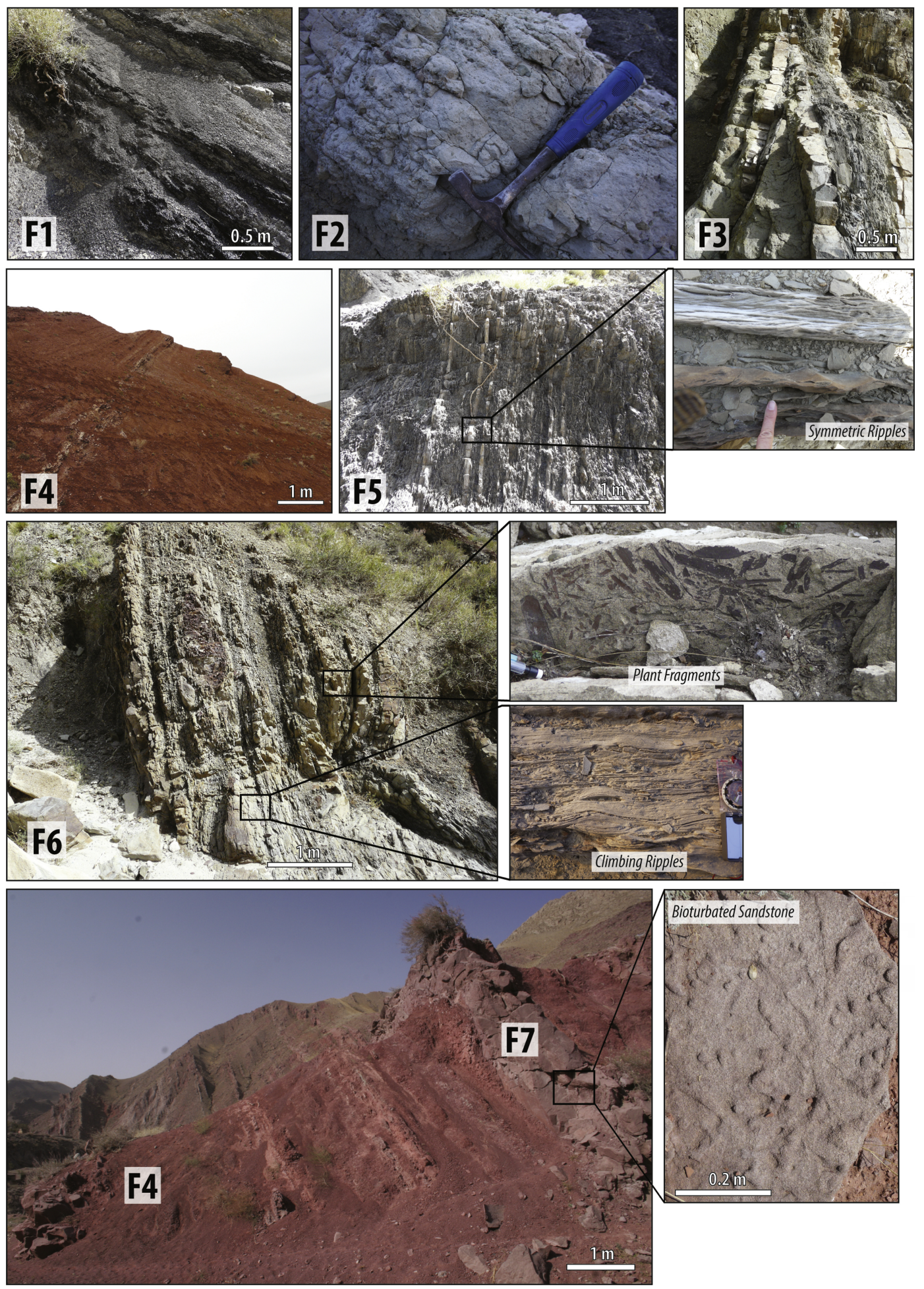

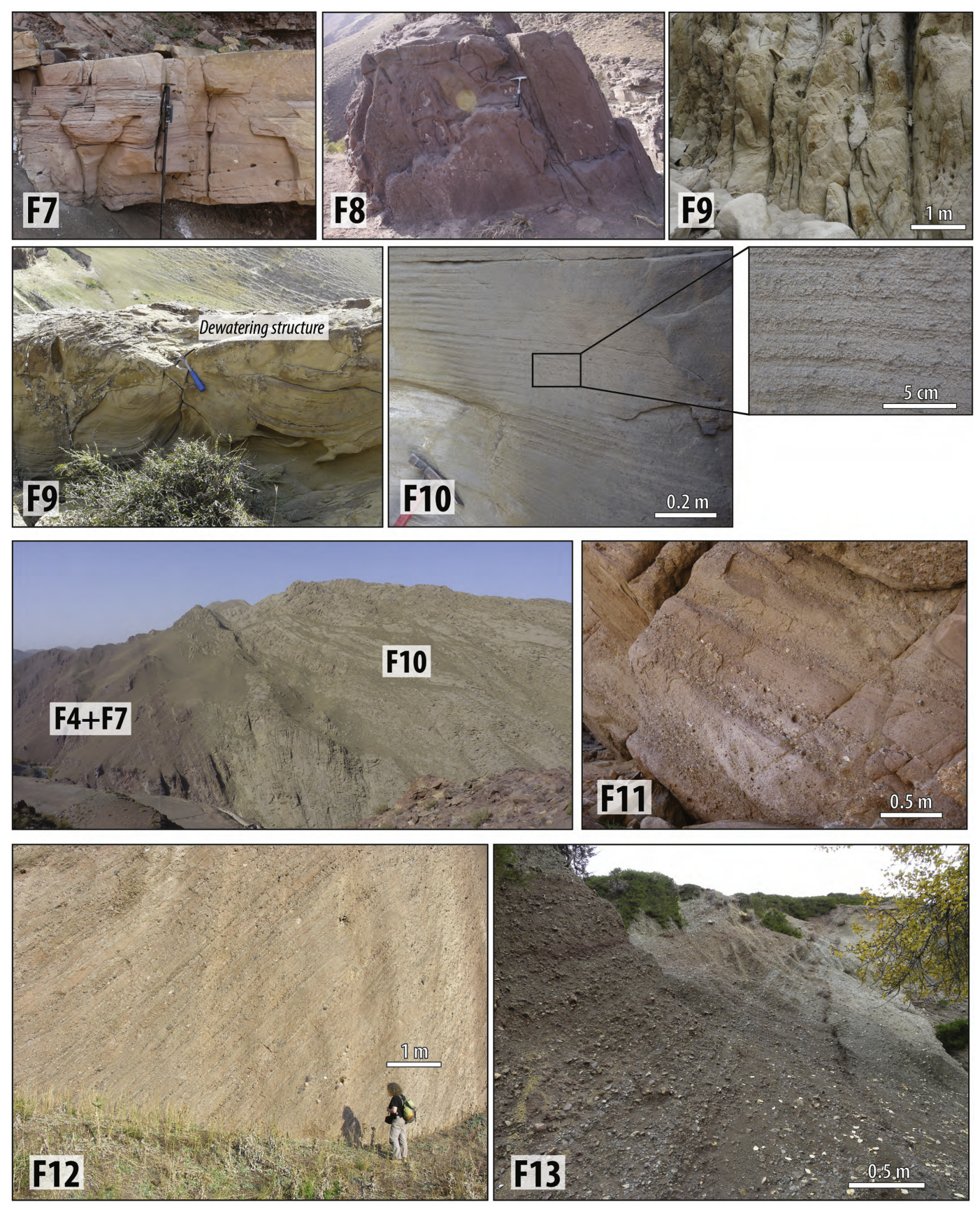

Figure 4 

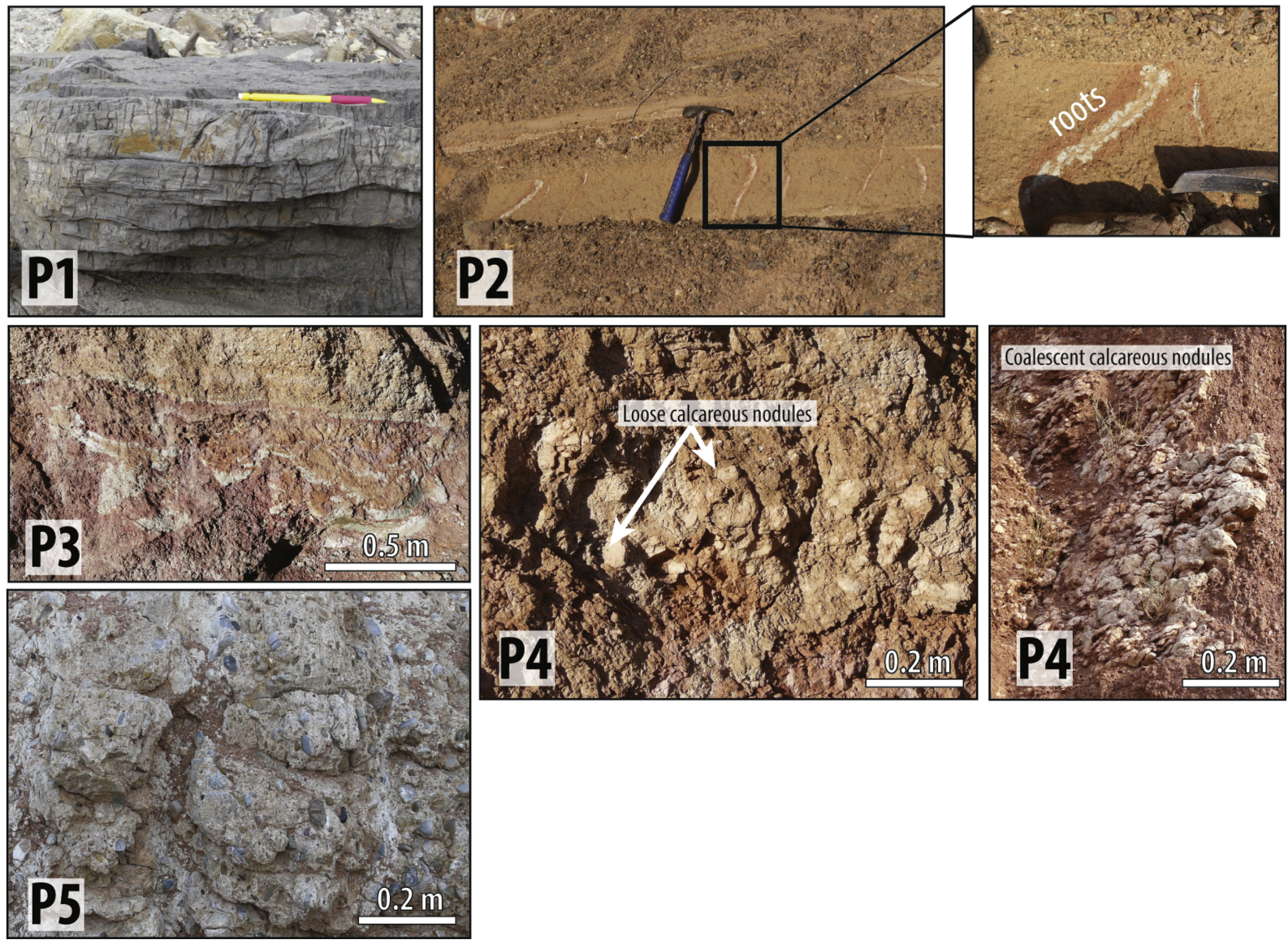

Figure 5 


\section{SOUTH TOUTUNHE SECTION}

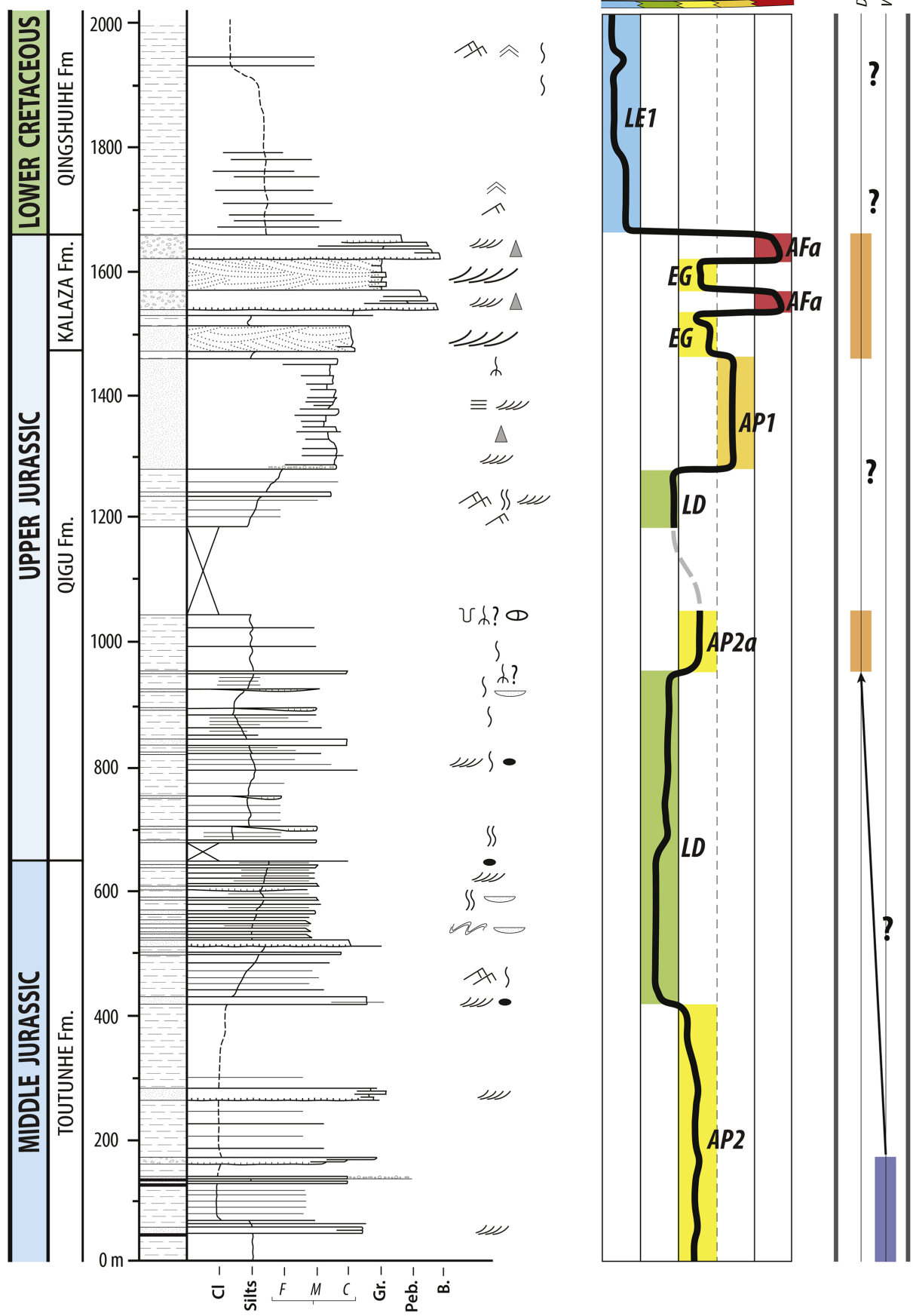

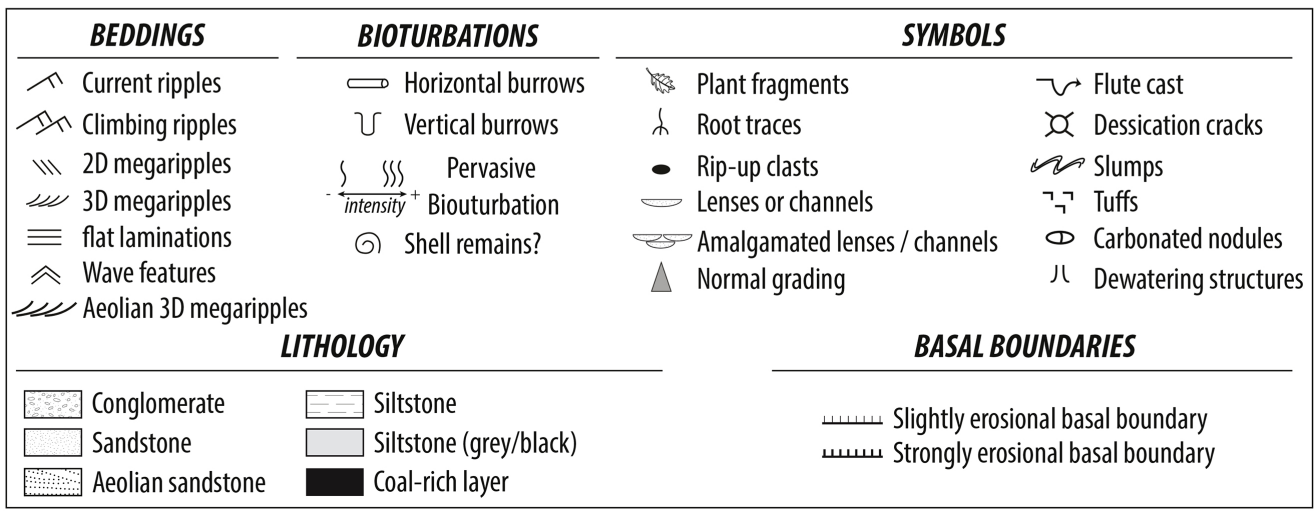




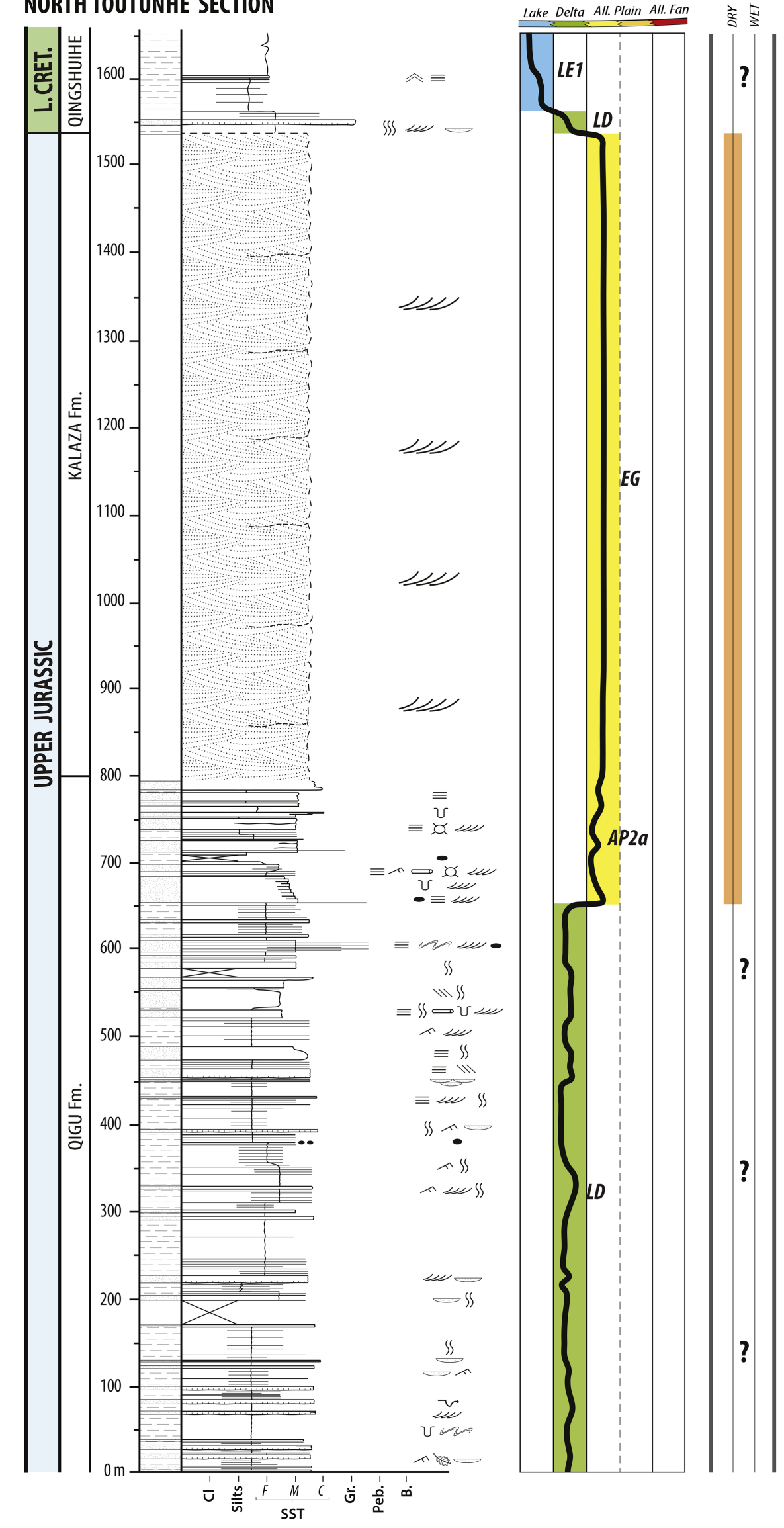

Figure 7 


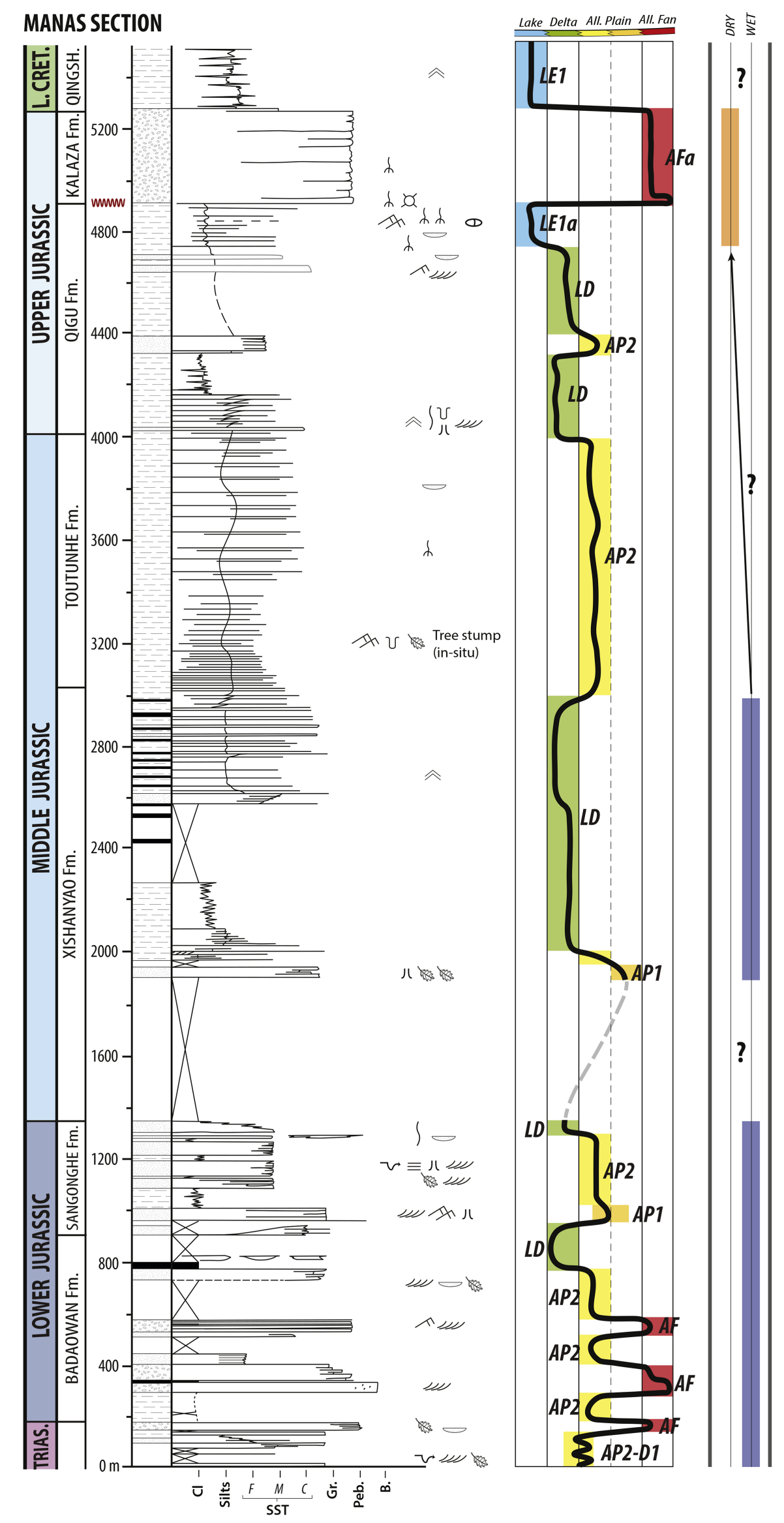




\section{WUSU SECTION}

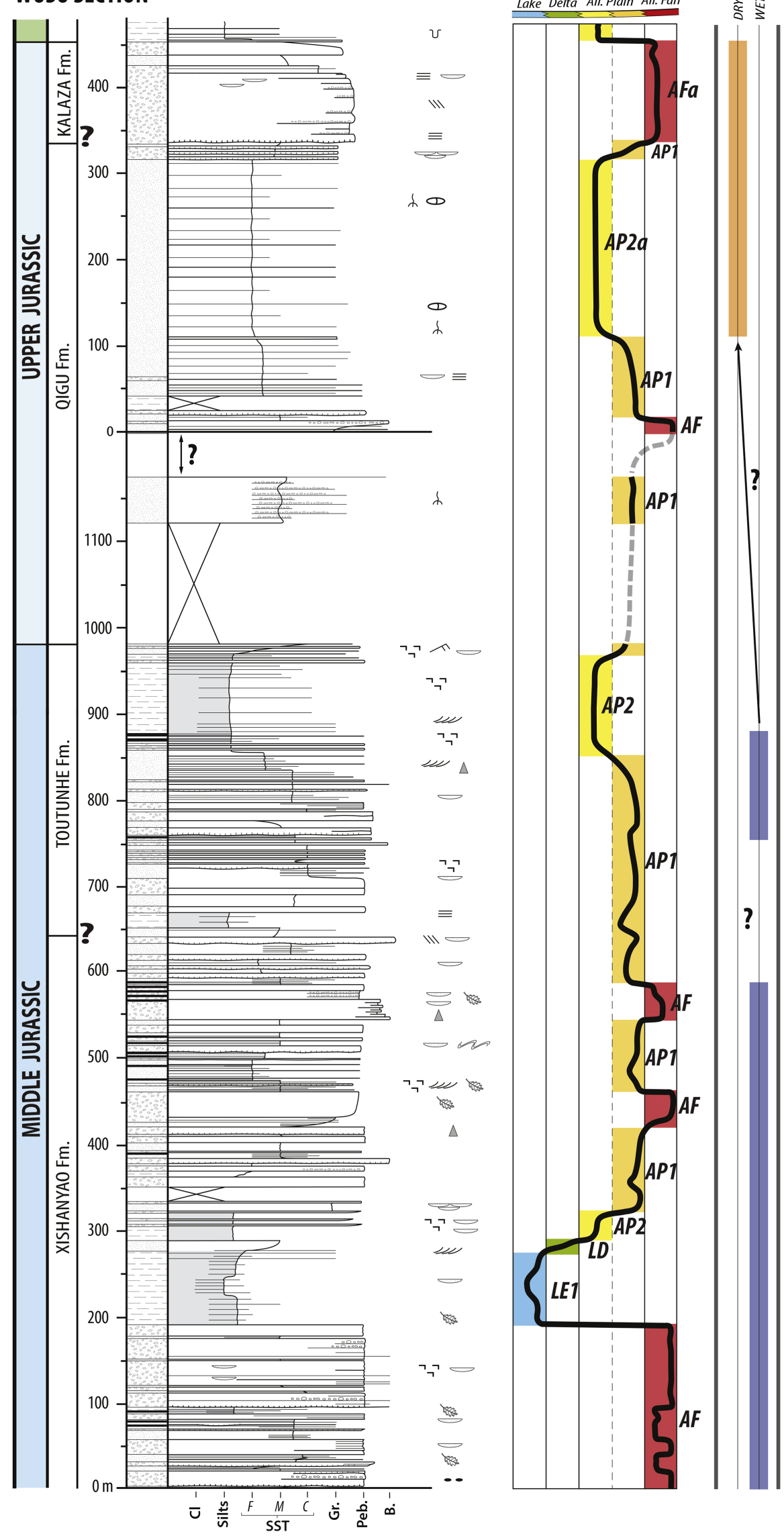

客 


\section{NIELEKE SECTION}

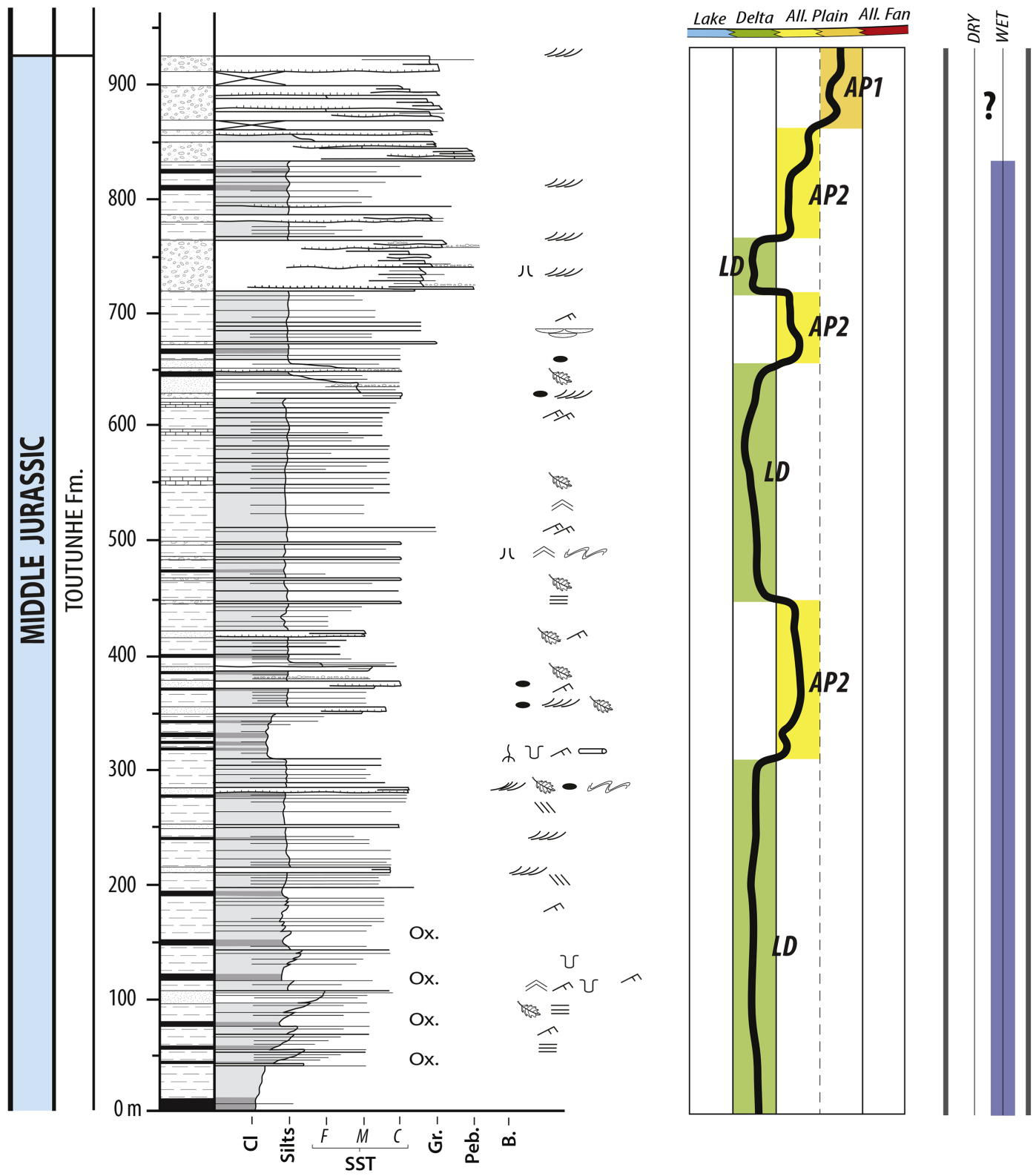

Figure 10 


\section{BAYANBULAK SECTION}
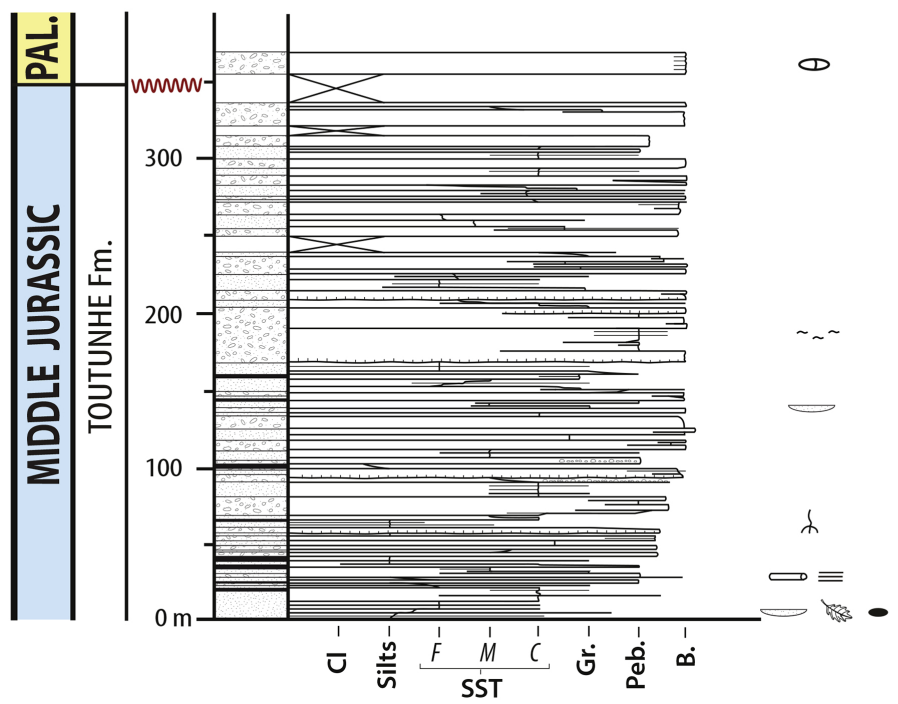

Lake Delta All. Plain All. Fan

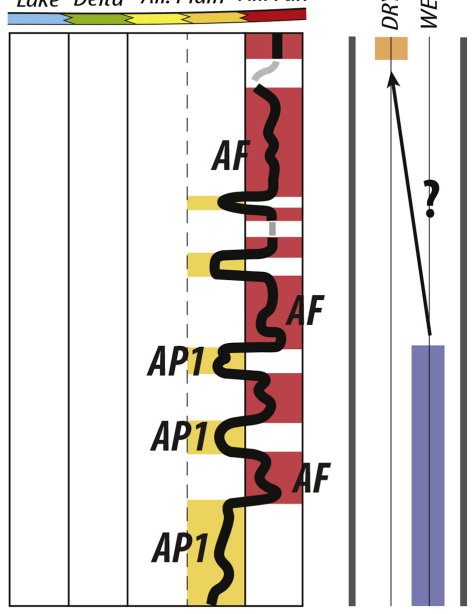

Figure 11 


\section{YAHA SECTION}

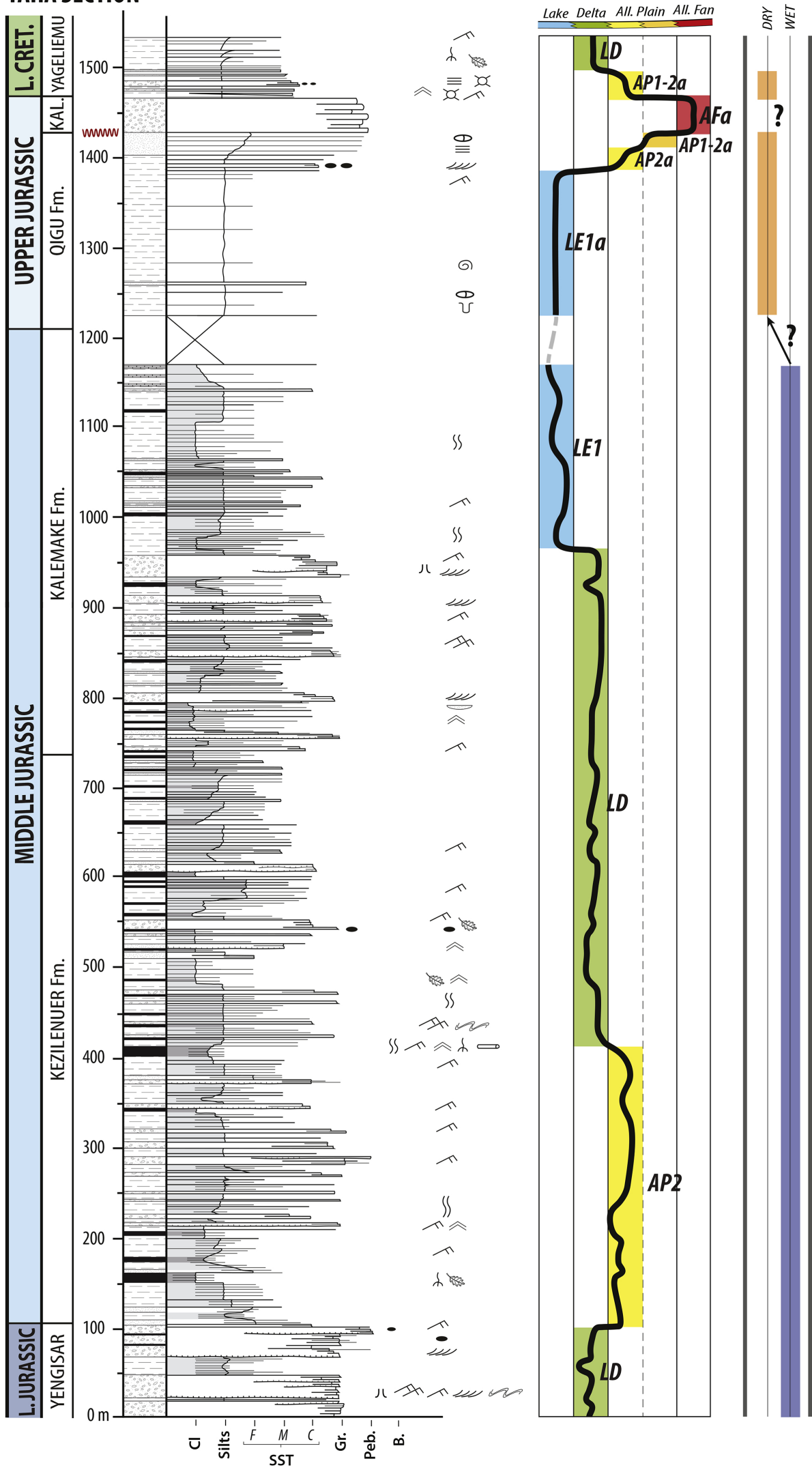




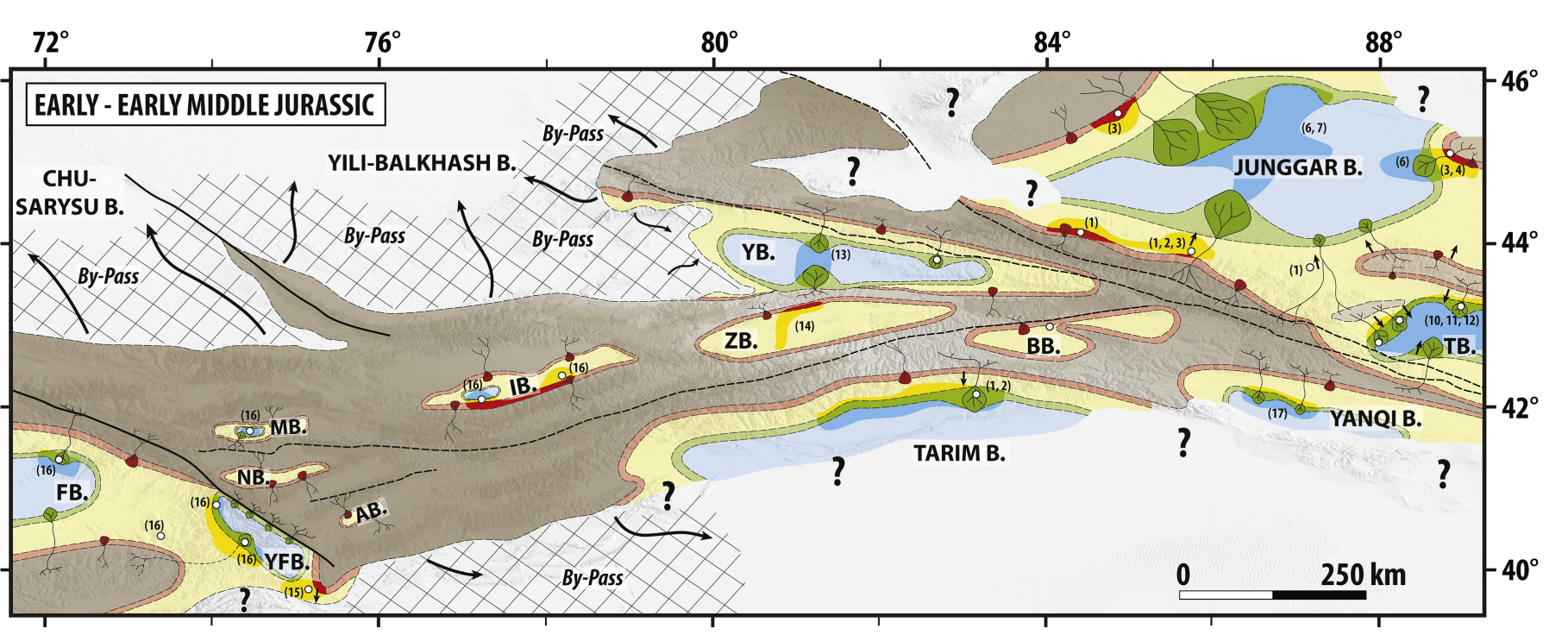

(1) This study ; (2) Hendrix et al., 1992; (3) Eberth et al., 2001; (4) Vincent et al., 2001; (5) Jolivet et al., 2017; (6) Feng et al., 2015; (7) Yang et al., 2015; (8) Lianhua et al., 2009; (9) Gao et al., 2017; (10) Shao et al., 1999; (11) Greene et al., 2001; (12) Shao et al., 2003; (13) Li et al., 2014; (14) Li et al., 2015; (15) Sobel et al., 1999; (16) De Pelsmaeker et al., 2018; (17) Al-Qaraafi and Guangqing, 2013

\begin{tabular}{|c|c|c|}
\hline \multicolumn{2}{|c|}{ Environments } & Structures \\
\hline 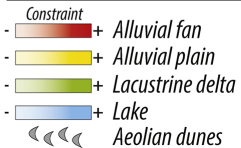 & $\begin{array}{ll}\text { Amplitude } & \text { Relief } \\
& \text { By-pass area } \\
\text { Volcanism }\end{array}$ & $\begin{array}{l}\searrow \text { Inferred active fault } \\
\checkmark \text {. Fault (undetermined) } I \text { Paleocurrents } \\
\text { O Sedimentary section }\end{array}$ \\
\hline
\end{tabular}




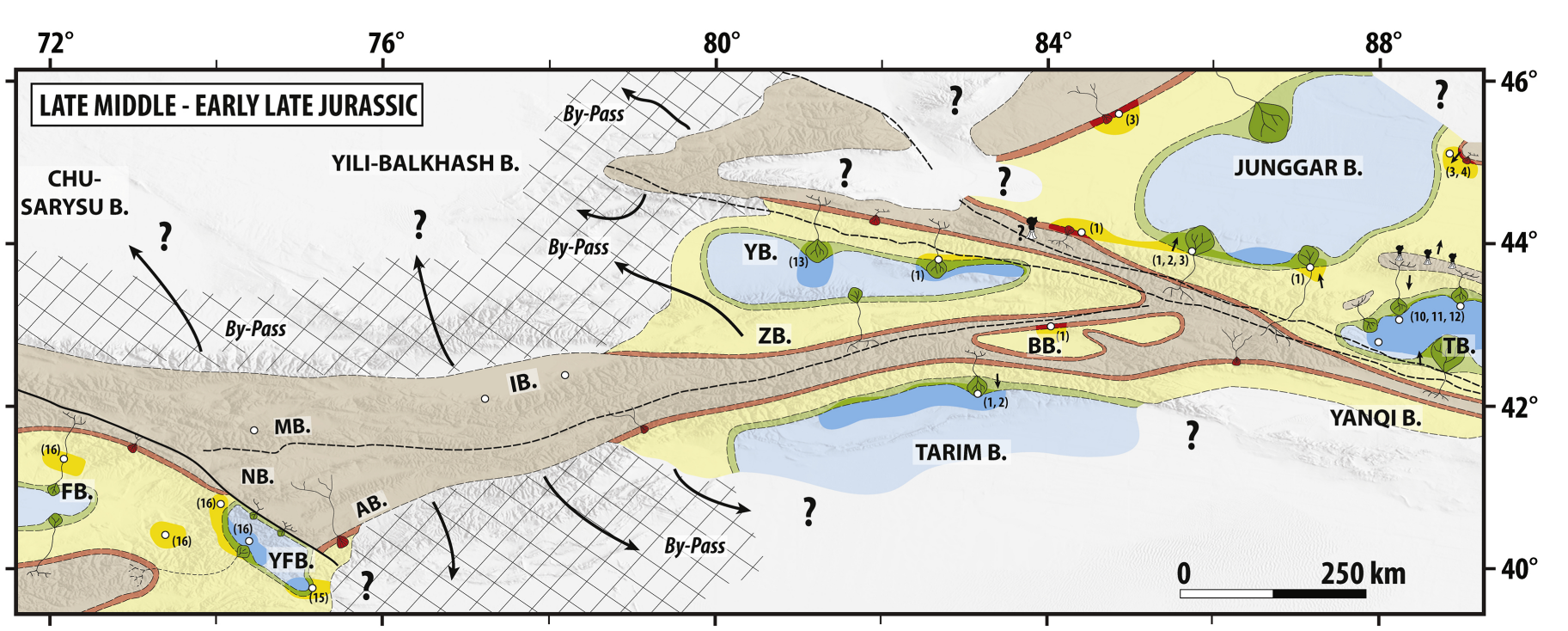

(1) This study ; (2) Hendrix et al., 1992; (3) Eberth et al., 2001; (4) Vincent et al., 2001; (5) Jolivet et al., 2017; (6) Feng et al., 2015; (7) Yang et al., 2015; (8) Lianhua et al., 2009; (9) Gao et al., 2017; (10) Shao et al., 1999; (11) Greene et al., 2001; (12) Shao et al., 2003; (13) Li et al., 2014; (14) Li et al., 2015; (15) Sobel et al., 1999; (16) De Pelsmaeker et al., 2018; (17) Al-Qaraafi and Guangqing, 2013

\begin{tabular}{|c|c|c|}
\hline \multicolumn{2}{|c|}{ Environments } & Structures \\
\hline $\begin{array}{l}\text { Constraint } \\
\begin{array}{l}\square \\
+\end{array}+\text { Alluvial fan } \\
-\square+\text { Alluvial plain } \\
+\square+\text { Lacustrine delta } \\
-\square+\text { Lake } \\
\square \mathbb{\&} \quad \text { Aeolian dunes }\end{array}$ & $\begin{array}{ll}\text { Amplitude } & \text { Relief } \\
\text { By-pass area } & \text { Volcanism }\end{array}$ & $\begin{array}{l}\backslash \text { Inferred active fault } \ \text { Potential sediment transport direction } \\
\checkmark \text {. Fault (undetermined) } \nearrow \text { Paleocurrents } \\
\text { O Sedimentary section }\end{array}$ \\
\hline
\end{tabular}




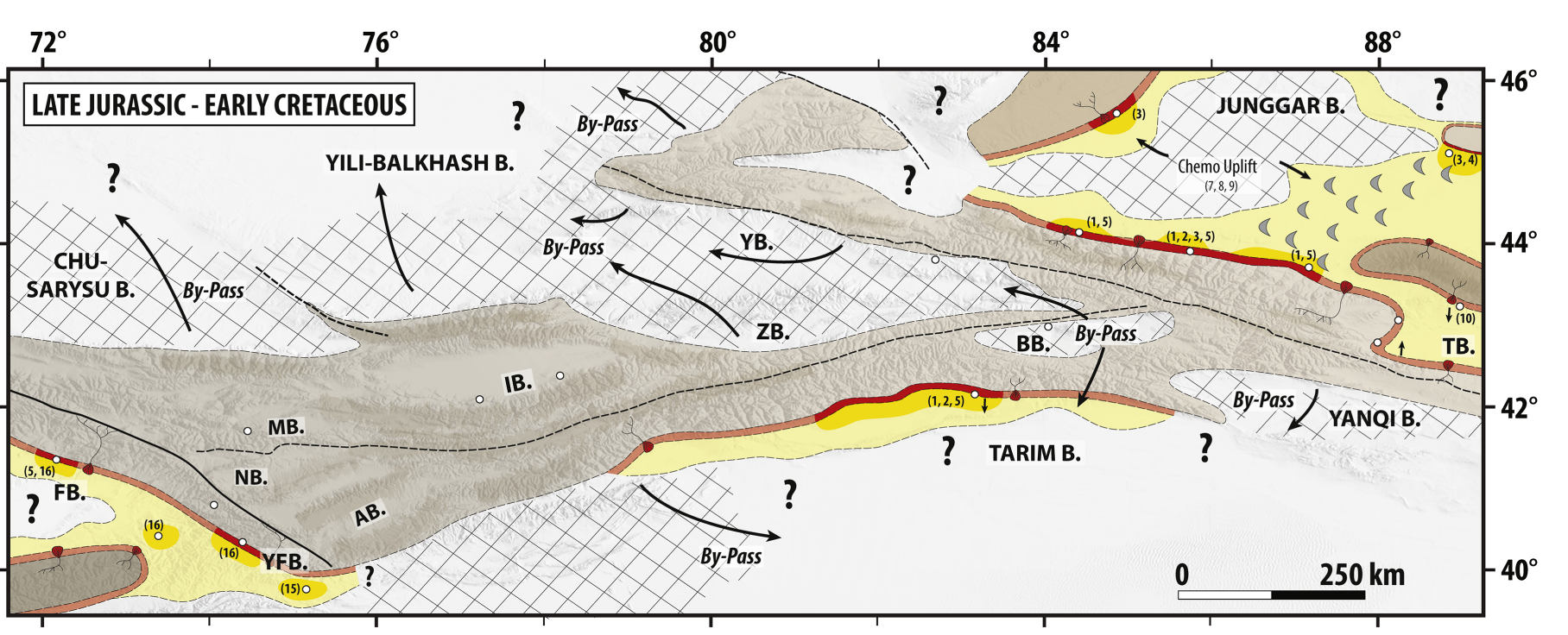

(1) This study ; (2) Hendrix et al., 1992; (3) Eberth et al., 2001; (4) Vincent et al., 2001; (5) Jolivet et al., 2017; (6) Feng et al., 2015; (7) Yang et al., 2015; (8) Lianhua et al., 2009; (9) Gao et al., 2017; (10) Shao et al., 1999; (11) Greene et al., 2001; (12) Shao et al., 2003; (13) Li et al., 2014; (14) Li et al., 2015; (15) Sobel et al., 1999; (16) De Pelsmaeker et al., 2018; (17) Al-Qaraafi and Guangqing, 2013

\begin{tabular}{|c|c|c|}
\hline \multicolumn{2}{|c|}{ Environments } & Structures \\
\hline 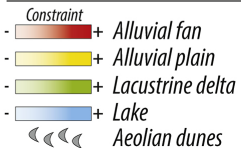 & $\begin{array}{ll}\text { Amplitude } & \text { Relief } \\
& \text { By-pass area } \\
\text { Volcanism }\end{array}$ & $\begin{array}{l}\searrow \text { Inferred active fault } \ \text { Potential sediment transport direction } \\
\checkmark \text {. Fault (undetermined) } \uparrow \text { Paleocurrents } \\
\text { O Sedimentary section }\end{array}$ \\
\hline
\end{tabular}




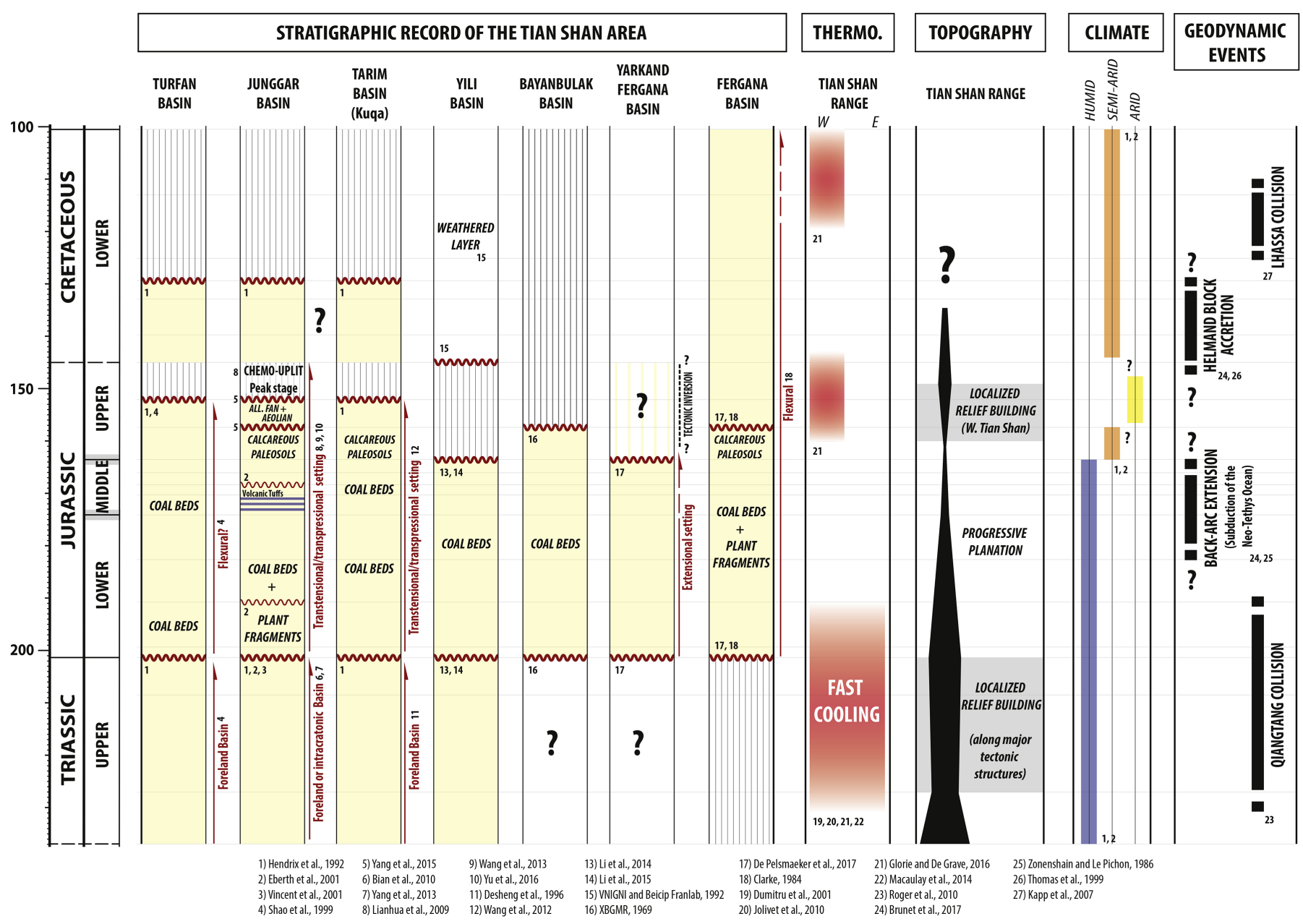




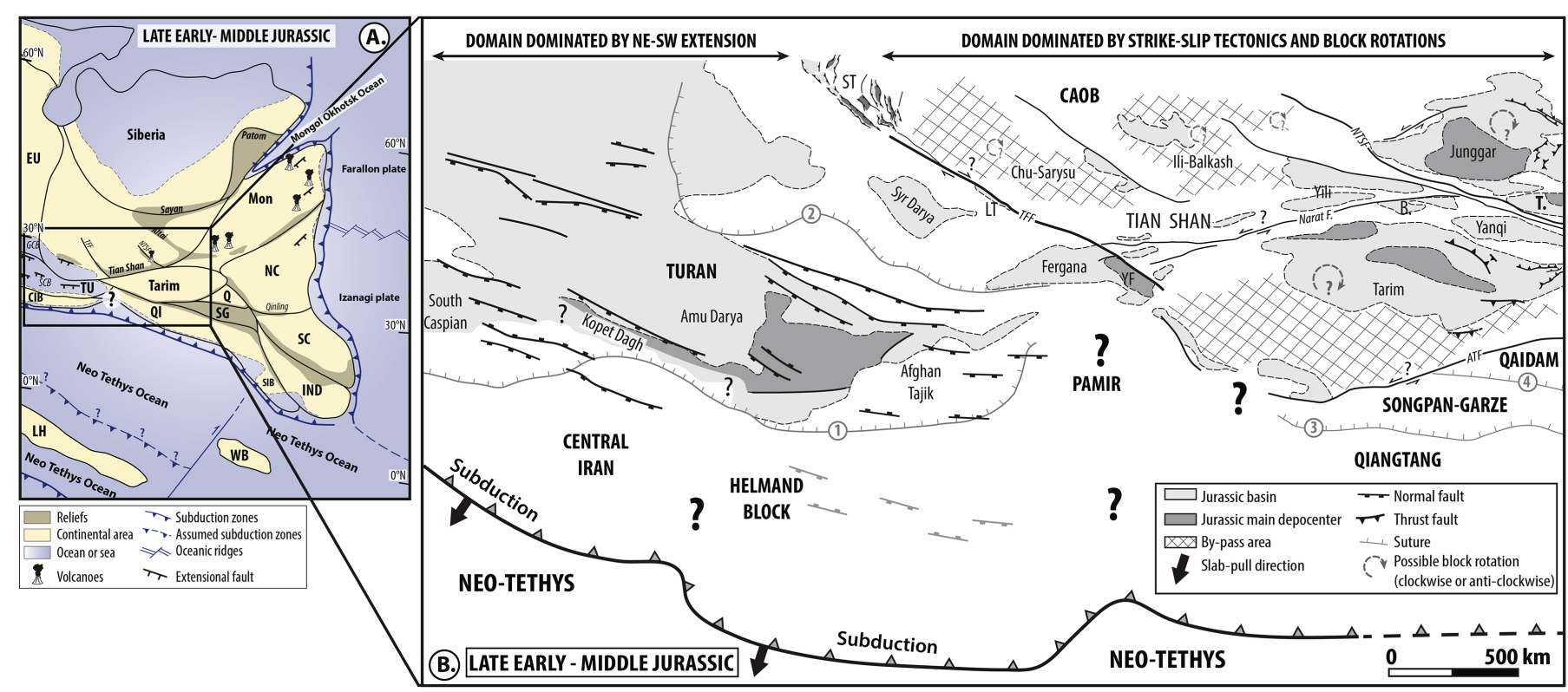

Figure 17 